ESTIMATION OF HYDRAULIC CONDUCTIVITY OF A RIVERBED AND AQUIFER SYSTEM ON THE SUSQUEHANNA RIVER

IN BROOME COUNTY, NEW YORK

By Richard M. Yager

U. S. Geological Survey

Open-File Report 91-457

Ithaca, New York 


\section{DEPARTMENT OF THE INTERIOR}

MANUEL LUJAN, JR., Secretary

\section{U. S. GEOLOGICAL SURVEY}

Dallas L. Peck, Director

For additional information write to:

Subdistrict Chief

U. S. Geological Survey

$521 \mathrm{~W}$. Seneca Street

Ithaca, NY 14850
Copies of this report may be purchased from:

U.S. Geological Survey Books \& Open-File Reports Section Federal Center, Bldg. 810 Box 25425 ,

Denver, CO. 80225 


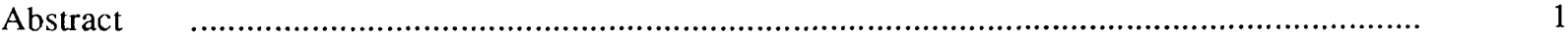

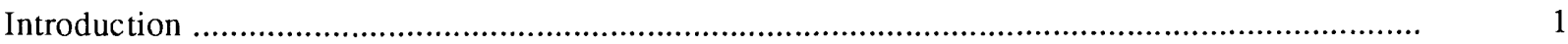

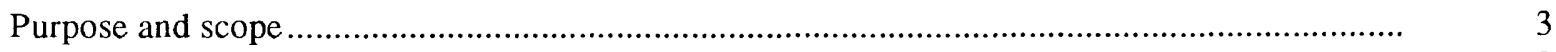

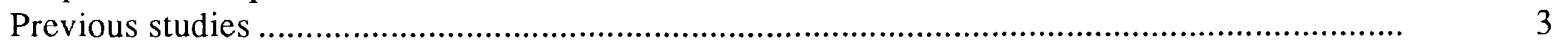

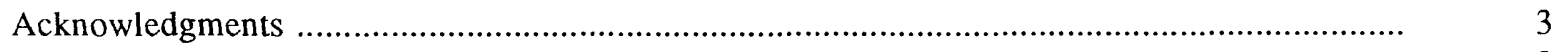

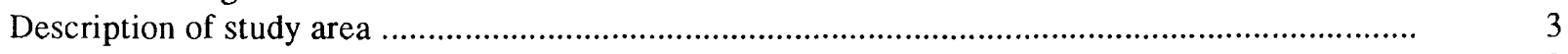

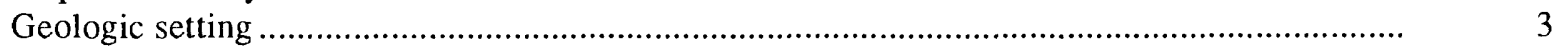

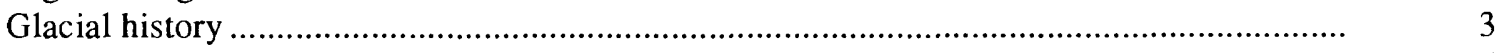

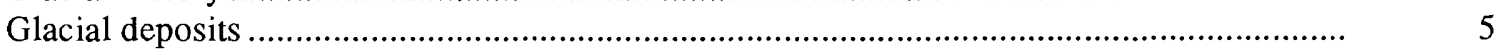

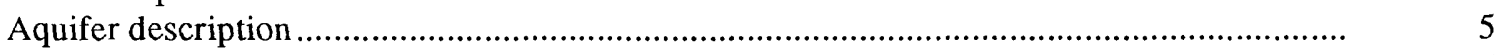

Hydrologic setting ..........................................................................................

Susquehanna River ......................................................................................

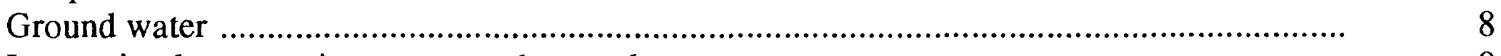

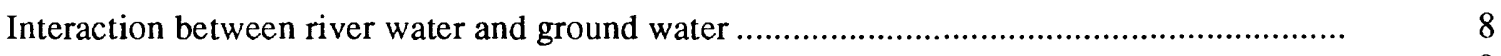

Ground-water temperatures .........................................................................

Riverbed characteristics ................................................................................ 10

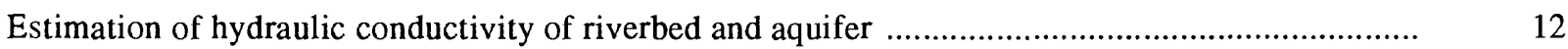

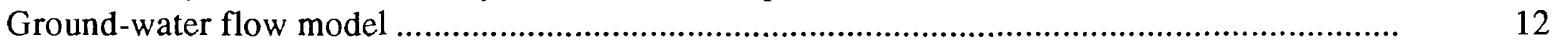

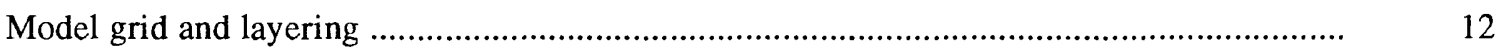

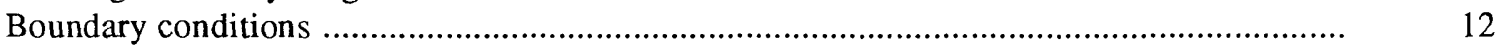

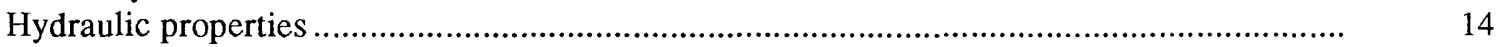

Hydraulic conductivity ........................................................................ 14

Anisotropy ......................................................................................

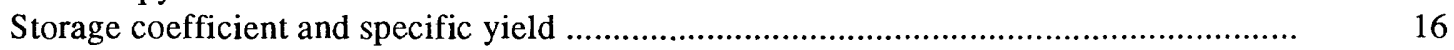

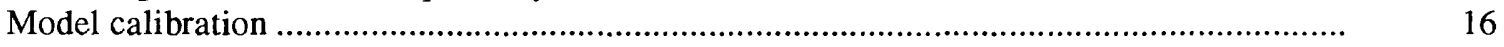

Simulation of ground-water withdrawals ........................................................

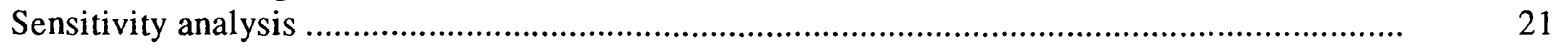

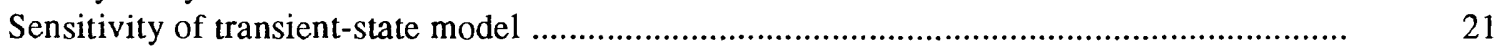

Residuals .................................................................................................. 21

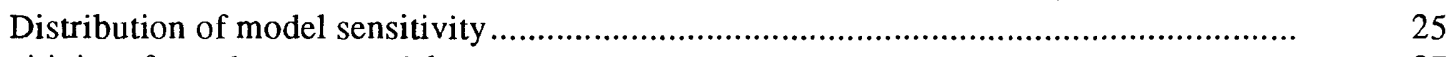

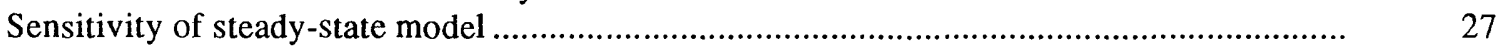

River infiltration to well field ....................................................................... 27

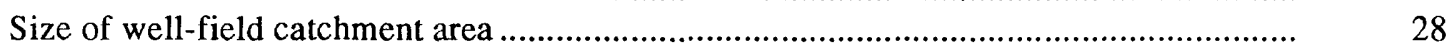

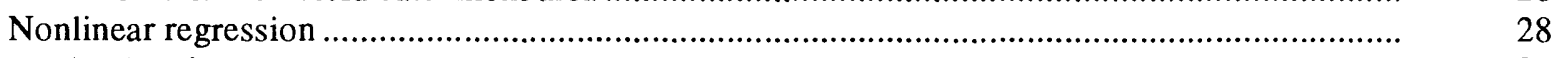

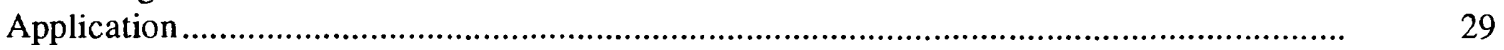

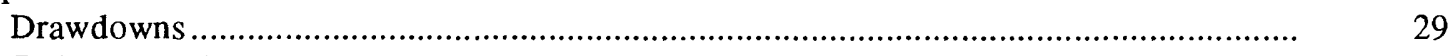

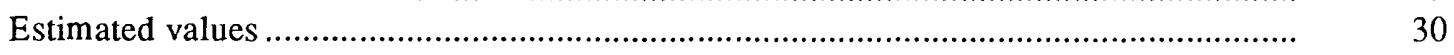

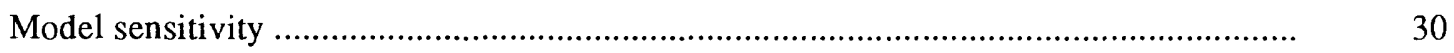

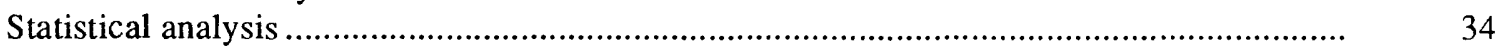

Analysis of residuals ...................................................................................

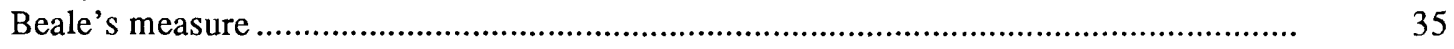

Confidence levels for regression-estimated values ................................................. 35

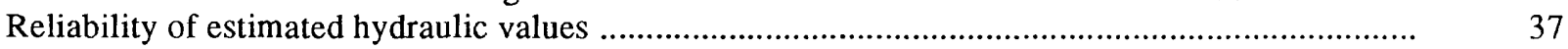

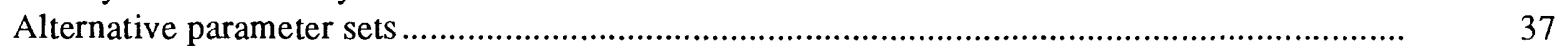

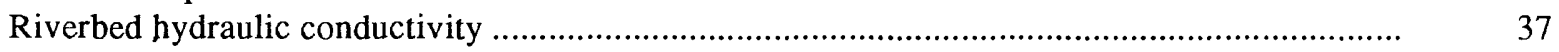

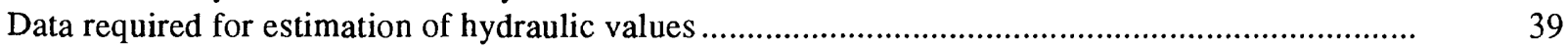

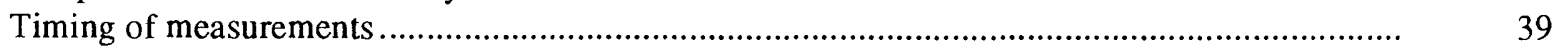

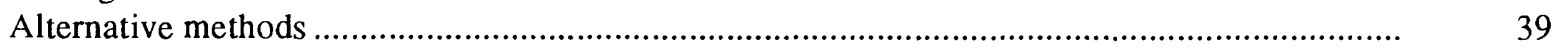

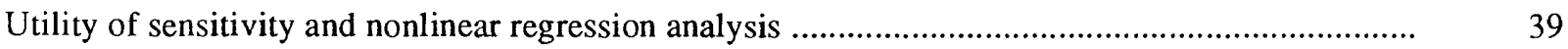

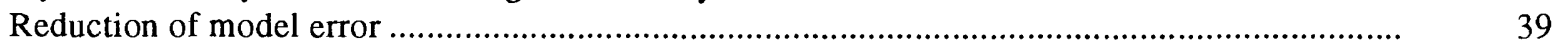




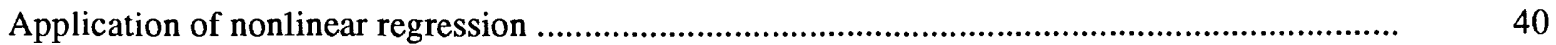

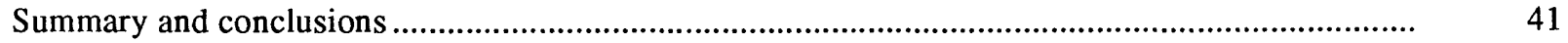

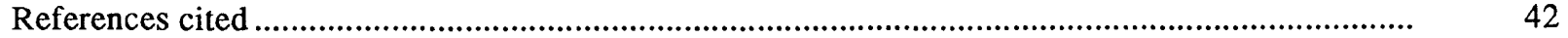

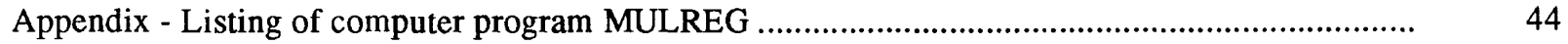

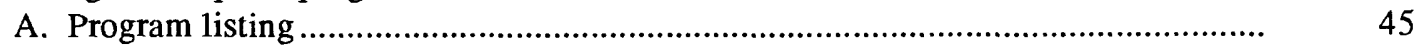

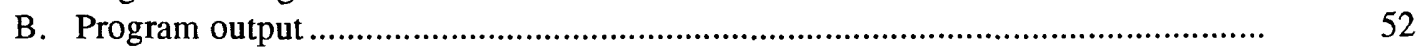

\section{ILLUSTRATIONS}

Figure 1-3. Maps showing:

1. Location of study area near Kirkwood, New York .......................................... 2

2. Glacial features near Great Bend area on the Susquehanna River.................... 4

3. Surficial geology of the Susquehanna River valley near Fivemile Point........... 6

4. Generalized geologic sections of Fivemile Point area

5. Graph showing mean daily discharge of the Susquehanna River at Conklin, October 1983 through September 1984 and median mean daily discharge during 1932-80 water years

6. Map showing average hydraulic head and direction of ground-water flow in Fivemile Point area in October 1984

7. Graph showing stage of Susquehanna River at Conklin and ground-water levels in observation well VO3 (250 ft from river), October 1983 through November 1984

8. Graphs showing seasonal variation in water temperature and river discharge, . August 1984 to October 1985:

A. Ground-water temperature in well GP1B (50 ft from river).

B. Temperature of the Susquehanna River at Conklin.

C. Discharge of the Susquehanna River at Conklin.

9. Detail of model grid near Kirkwood well field.

10. Schematic vertical profile of aquifer along section E-E' showing layers and boundaries used in model.

11. Maps showing distribution of hydraulic conductivity values in model:
A. Layer 1.
B. Layer 2 .
C. Layer 3.
D. Layer 4.

12. Maps showing distribution of drawdowns in model layers 2 and 3 computed by transient-state simulation of October 1984 aquifer test

13. Generalized sections E-E' and F-F' showing vertical distribution of drawdowns computed by transient-state simulation of October 1984 aquifer test

14. Graph showing difference between observed drawdowns and drawdowns computed by transient-state simulation, plotted in relation to computed drawdowns 


\section{ILLUSTRATIONS (continued)}

Page

Figure 15. Maps showing distribution of differences between observed drawdowns and drawdowns computed by transient-state simulation in upper and lower parts of aquifer.

16. Graph showing drawdown as a function of time in observation wells GS8A and GS8B measured during February 1984 aquifer test and computed by transient-state simulation with calibrated model

17. Graph showing daily gage height of the Susquehanna River at Conklin, October 1984

18. Map showing catchment area for production wells and direction of ground-water flow derived from steady-state simulation of ground-water withdrawals

19. Map showing water-table contours derived from steady-state simulation of ground-water withdrawals

20. Graphs showing model sensitivity to selected aquifer properties, expressed as root-mean-square difference between simulated and observed drawdown over the range of values tested:
A. Anisotropy of lower part of aquifer.
B. Vertical hydraulic conductivity of riverbed.
C. Maximum hydraulic conductivity of aquifer.
D. Specific yield.
E. Storage coefficient.

21. Graph showing type curves relating drawdown to time in a fully penetrating observation well (VO3), for values of $\sigma$ (ratio of storage coefficient to specific yield) included in sensitivity analysis, calculated by Neuman's method (1975) to account for partial penetration in production well GP1

22. Maps showing change in simulated drawdown resulting from changes in values of aquifer properties in sensitivity analysis

A. In model layer 1 with vertical hydraulic conductivity of riverbed $(\mathrm{Kr})$ increased tenfold, from 0.1 to $1.0 \mathrm{ft}$.

B. In model layer 3 with maximum hydraulic conductivity of aquifer (Kmax) decreased by 80 percent, from 10,000 to $2,000 \mathrm{ft} / \mathrm{d}$.

C. In model layer 3 with anisotropy (Kv) doubled from 125 to 250 in lower part of aquifer and from 250 to 500 in upper part.

23. Graphs showing percentage of river water in water pumped from the Kirkwood well field as a function of aquifer properties
A. Anisotropy of lower part of aquifer.
B. Maximum hydraulic conductivity of aquifer.
C. Vertical hydraulic conductivity of riverbed.

24. Graph showing size of well-field catchment area as a function of vertical hydraulic conductivity of riverbed

25. Graph showing changes in values of aquifer properties during nonlinear regression

26. Maps showing distribution of drawdowns in model layers 2 and 3 computed by transient-state simulation of October 1984 aquifer test based on nonlinear regression values 


\section{ILLUSTRATIONS (continued)}

Figure 27. Maps showing distribution of model sensitivity to respective aquifer properties........
A. Base values of hydraulic conductivity (Kbase) in model layers 2 and 3.
B. Anisotropy of upper part of aquifer (Kv1) in model layers 2 and 3.
C. Maximum hydraulic conductivity of aquifer in model layers 2 and 3.

28. Graph showing difference between observed drawdowns and those computed from nonlinear regression values by transient-state simulation, plotted in relation to computed drawdowns

29. Graphs showing difference between observed drawdowns and those computed from nonlinear regression values by transient-state simulation in the upper and lower parts of the aquifer .

30. Normal probability plots for residuals.

A. Model residuals, $\mathrm{e}_{\mathrm{i}}$.

B. Uncorrelated, random normal deviates, $\mathrm{d}_{\mathrm{i}}$.

C. Simulated residuals, $\mathrm{g}_{\mathrm{i}}$.

31. Graph showing model error during model calibration and nonlinear regression

\section{PLATE \\ (in pocket)}

Plate 1. A. Map of study area showing location of aquifer, river channel, and geologic sections, wells, and test borings.

B. Map of study area showing finite-difference grid and boundaries of model.

\section{TABLES}

Table 1. Drawdowns after 23 hours of pumping computed by transient-state simulation of aquifer test inOctober 1984 at Kirkwood well field

2. Recharge to Kirkwood well-field catchment from major sources during October 1984

3. Aquifer properties investigated in sensitivity analysis

4. Values of aquifer properties obtained through nonlinear regression.

5. Statistics of residuals obtained by calibration and nonlinear regression

6. Correlation and covariance matrices for optimum values obtained through regression analysis

7. Values of aquifer properties estimated by regression and their confidence intervals at 95-percent level.

8. Values of aquifer properties estimated through simulation of ground-water flow

A-1. Input and output data used in computer program MULREG 


\section{CONVERSION FACTORS}

For the convenience of readers who prefer metric (International System) units to the inch-pound unit used in this report, the following conversion factors may be used:

Multiply Inch-Pound Unit

foot $(\mathrm{ft})$

mile (mi)
By

\section{Length}

25.4

0.3048

1.609

Area

square mile $\left(\mathrm{mi}^{2}\right)$

acre

Flow

gallon per minute (gal/min)

cubic foot per second $\left(\mathrm{ft}^{3} / \mathrm{s}\right)$

inch per year (in/yr)

foot squared per day $\left(\mathrm{ft}^{2} / \mathrm{d}\right)$

Hydraulic conductivity

foot per day (ft/d)

foot per mile $(\mathrm{ft} / \mathrm{mi})$

degrees Fahrenheit $\left({ }^{\circ} \mathrm{F}\right)$
0.0929

0.3048

0.1894

Temperature

0.06309

0.02832

25.4

Transmissivity

${ }^{\circ} \mathrm{C}=5 / 9\left({ }^{\circ} \mathrm{F}-32\right)$
To Obtain Metric Unit

millimeter $(\mathrm{mm})$

meter $(\mathrm{m})$

kilometer $(\mathrm{m})$ square kilometer $\left(\mathrm{km}^{2}\right)$ hectare (ha) liter per second $(\mathrm{L} / \mathrm{s})$

cubic meter per second $\left(\mathrm{m}^{3} / \mathrm{s}\right)$ millimeter per year $(\mathrm{mm} / \mathrm{yr})$

meter squared per day $\left(\mathrm{m}^{2} / \mathrm{d}\right)$

meter per day $(\mathrm{m} / \mathrm{d})$

meter per kilometer $(\mathrm{m} / \mathrm{km})$

(a)

(1)

degrees Celsius $\left({ }^{\circ} \mathrm{C}\right)$

Sea level Datum: In this report "sea level" refers to the National Geodetic Vertical Datum of 1929 (NGVD of 1929)--a geodetic datum derived from a general adjustment of the first-order level nets of both the United States and Canada, formerly called "Sea Level Datum of 1929." 


\title{
Estimation of Hydraulic Conductivity of a Riverbed and Aquifer System on the Susquehanna River in Broome County, New York
}

\author{
By Richard M. Yager
}

\begin{abstract}
A three-dimensional finite-difference model of ground-water flow was used to estimate the hydraulic conductivity of riverbed and aquifer material in a 1-square-mile valley-fill aquifer system near a large river in which induced infiltration due to pumping cannot be measured directly. The aquifer consists of a 30- to 70-foot thickness of sand and gravel containing discontinuous layers of compact and silty sand and gravel.

Horizontal hydraulic conductivity of the aquifer material, estimated through trial-and-error calibration of simulated water levels to drawdowns measured during an aquifer test, ranged from 500 to 10,000 feet per day; anisotropy (ratio of horizontal to vertical hydraulic conductivity) ranged from 125:1 to $250: 1$. The vertical hydraulic conductivity of the riverbed was estimated to be 0.1 to 0.5 feet per day, whereas permeameter tests on samples of silty sand and gravel layers from the riverbed yielded vertical hydraulic conductivity of $10^{-3}$ feet per day.

A sensitivity analysis indicated that a narrow range of anisotropy values gave the smallest residual error in simulated drawdowns. Residual error increased sharply when the maximum hydraulic conductivity value for the aquifer was lowered to less than 5,000 feet per day. Residual error also was large for large values of vertical hydraulic conductivity of the riverbed, but decreased to a constant amount for values less than 0.1 feet per day. Residual error was relatively insensitive to changes in the storage coefficient and specific yield.

A nonlinear regression method that approximated the sensitivity matrix with a perturbation technique was applied to refine the estimates of these parameters and compute standard error of the estimates. The nonlinear regression indicated that the model was sensitive to hydraulic conductivity of the aquifer and anisotropy of the upper part of the aquifer but not to anisotropy of the lower part, and that vertical hydraulic conductivity of the riverbed was less than 0.5 feet per day. The regression method yielded aquifer hydraulic-conductivity values of 210 to 13,000 feet per day and an anisotropy ratio of 350:1 for the upper part of the aquifer; the standard error of these estimates was relatively small. In contrast, the standard errors of estimates of anisotropy in the lower part of the aquifer and the vertical hydraulic conductivity of the riverbed were extremely large.
\end{abstract}

\section{INTRODUCTION}

A common feature of most sand and gravel aquifers in the northeastern United States is the hydraulic connection to streams or lakes. Assessments of groundwater supplies and aquifer response to pumping stresses require information on pumping effects on water levels in lakes or reduction in streamflow, but few studies have provided such information.

In 1984 the Northeastern Glacial Valley Regional Aquifer System Analysis program of the U.S. Geological Survey began the investigation of a small valley-fill aquifer in the Susquehanna River Valley at Fivemile Point in the town of Kirkwood, Broome County, N.Y. (fig. 1) to determine the effect of pumping stresses on the river. This aquifer covers much of the valley floor and is in hydraulic contact with the river. As in many heavily pumped valley-fill aquifers in the Northeast, the rate of infiltration from the river into the aquifer in response to pumping is so small rel- ative to river discharge that it cannot be accurately measured by streamflow-measuring procedures. A threedimensional finite-difference ground-water flow model developed in an earlier study of the Kirkwood well field (Yager, 1986) was previously used to estimate the rate at which infiltration from the river is induced by pumping and thus serves as a source of recharge to the well field. Specific objectives of this study were to:

1. Estimate the uncertainty in hydraulic conductivity values of the riverbed and aquifer material derived from model simulation of ground-water flow.

2. Suggest or develop approaches and data-collection programs that could refine the estimates of riverbed hydraulic conductivity.

3. Demonstrate the utility of model-sensitivity and nonlinear regression analysis in assessing the reliability of hydraulic conductivity values obtained through the simulation studies. 


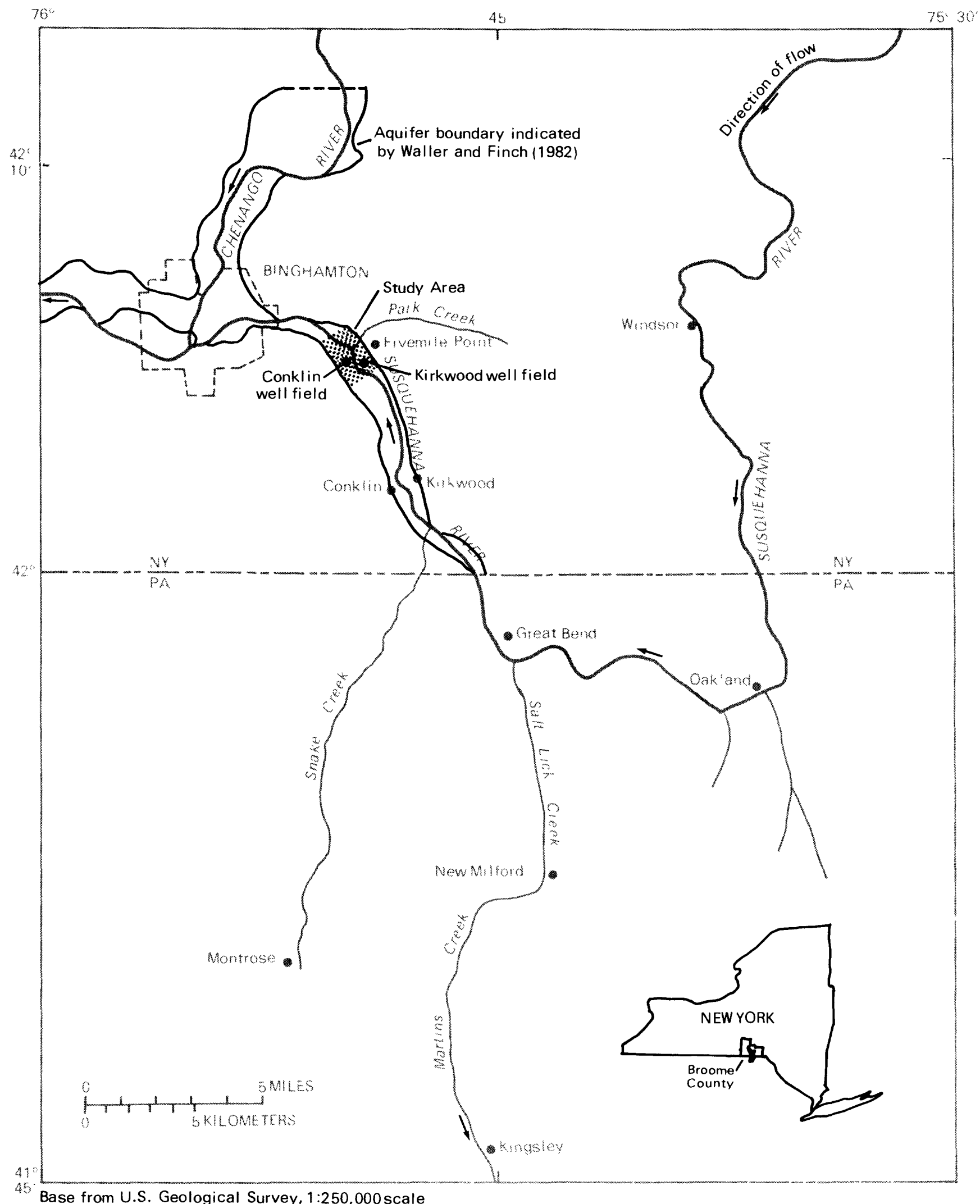

Figure 1.--Location of study area near Kirkwood, N.Y. 


\section{Purpose and Scope}

This report describes a procedure for estimating hydraulic conductivity values of riverbed and aquifer material through a simulation model of ground-water flow. It also (1) summarizes the geology and hydrology of the riverbed and aquifer system; (2) describes the ground-water flow model used to simulate this system; and (3) presents results of the sensitivity and nonlinear regression analyses that were used to evaluate the reliability of the hydraulic conductivity estimates.

\section{Previous Studies}

Lyford and others (1984) summarized hydraulic values obtained in several studies of glacial aquifers in the Northeast. Haeni (1978) obtained riverbed core samples from the Pootatuck River in Connecticut and conducted permeameter tests on two of the samples. Lapham (1989) estimated riverbed hydraulic conductiv- ity of the Ware River in Massachusetts by simulating temperature variation with a one-dimensional model. Dysart (1988) measured concentrations of dissolved oxygen and environmental-isotope ratios to estimate infiltration induced by pumping near the Rockaway River in New Jersey. Coates (1973) and Harrison (1966) described the geology of the study area. Randall $(1972,1986)$ and MacNish and Randall (1982) did detailed geohydrologic studies within the study area. Yager (1986) described the development of the threedimensional ground-water flow model used during this study.

\section{Acknowledgments}

The author thanks Richard Cooley of the Geological Survey in Denver, Colo., for providing assistance in the application of the nonlinear regression method, and David Boldt of the Geological Survey in Reston, Va. for developing computer code used to apply the method.

\section{DESCRIPTION OF STUDY AREA}

The study area is part of a narrow valley located about $10 \mathrm{mi}$ downstream of the Great Bend reach of the Susquehanna River (fig. 1). The area lies near the western boundary of the Appalachian plateau; the higher and more rugged Catskill mountains lie $10 \mathrm{mi}$ (miles) to the east. Altitudes range from 1,800 to $2,000 \mathrm{ft}$ (feet) above sea level on hilltops and from 840 to $860 \mathrm{ft}$ on the valley floor.

\section{Geologic Setting}

The aquifer investigated during this study encompasses part of the unconsolidated deposits of sand and gravel beneath the Susquehanna and Chenango River Valleys, which intersect at Binghamton (fig. 1). These deposits were left by meltwater streams emanating from glaciers. The most productive deposits are discontinuous and are considered to be separate aquifers (Waller and Finch, 1982, p. 48). The study area occupies approximately $1 \mathrm{mi}^{2}$ (square mile) of the valley floor just east of the city of Binghamton near the confluence of Park Creek and the Susquehanna River (fig. 1).

\section{Glacial History}

The Susquehanna River Valley in this area was carved by a preglacial river and was deepened and widened through erosion by glacial ice. Repeated glaciations formed glacial troughs that served as conduits for the southward flowing ice (fig. 2). These troughs are characterized by oversteepened hill slopes and truncated bedrock spurs. Coates $(1973$, p. 6) states that the ice sheet was at least 3,000 ft thick in this region, and that the maximum thickness of ice cover on hilltops was $1,000 \mathrm{ft}$. He further suggests that concentration of ice around the Catskill mountains could have caused westward surges in the glacial margin that may be responsible for the curvature of the Susquehanna River through the Great Bend area. During the glacial advance, the ice deposited large quantities of unstratified drift, chiefly in valleys oriented perpendicular to ice flow and on the lee side of hills (Coates, 1966).

During the waning stages of glaciation, the receding ice tongue in the Susquehanna River Valley was bounded by a lake dammed by higher land to the south. The outlet of this lake was probably the New Milford sluiceway (fig. 2), a 400 -ft-deep bedrock gorge now occupied by Martin Creek. The flat floor and lack of tributary drainage suggest that this channel was cut by meltwater draining the proglacial lakes. A hanging delta in the valley of Salt Lick Creek lies at the same altitude as the bottom of the sluiceway, which indicates a final lake stage of 1,140 to $1,150 \mathrm{ft}$ (Coates, 1973, p. 73).

As the ice receded northward, meltwater streams deposited stratified drift in the proglacial lake. Ice-contact deposits, including a large esker over $100 \mathrm{ft}$ thick, occupy the valley at Oakland. Lacustrine deposits up to $70 \mathrm{ft}$ thick underlie the valley floor from Great Bend to Binghamton. A major drop in the lake stage probably occurred as the ice margin receded through the study area at Fivemile Point and opened a lower outlet for drainage to the west through Binghamton. This change in lake drainage could have been a catastrophic event 


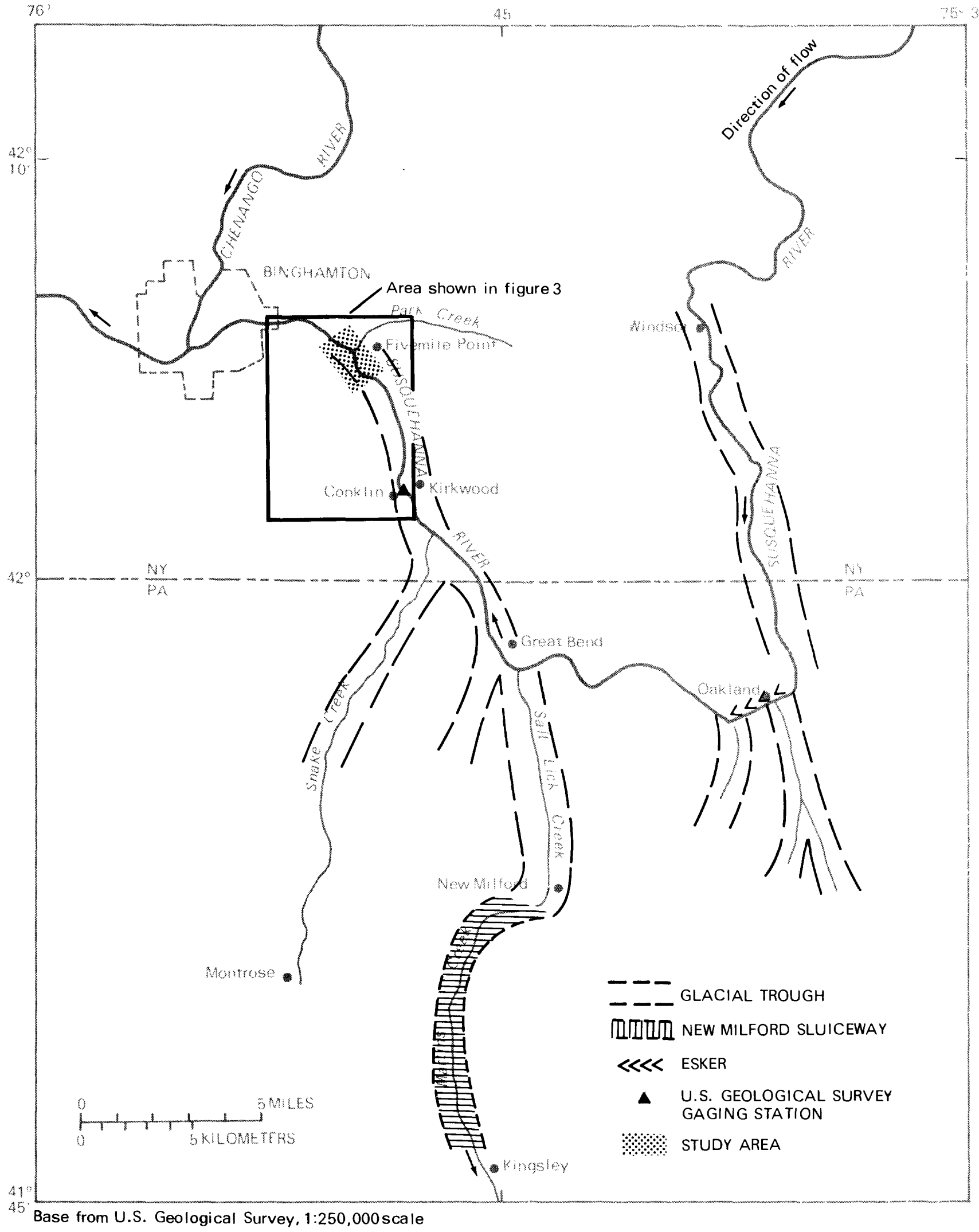

Figure 2.--Glacial features near Greai Bend area on the Susquehanna River. 
accompanied by sudden erosion and deposition of large amounts of material within the study area. Isolated deposits of sand and gravel along the sides of the Susquehanna River Valley upstream of Binghamton (Randall and Coates, 1973, p. 45; and Randall, 1978, p. 5), mapped by Lounsbury and others (1932), suggest that the lake stage controlled by the Binghamton outlet was 900 to $920 \mathrm{ft}$ above sea level.

After the establishment of westward drainage through Binghamton, an extensive layer of sand and gravel was deposited on the valley floor as meltwater drained from ice north of Windsor. This material could have been washed out of (1) stagnant ice on the valley floor, (2) ice remnants occupying the surrounding uplands, or (3) freshly exposed till incised by upland streams. The Susquehanna River subsequently deposited a flood plain of sand and silt over the sand and gravel. The river channel is now incised about $10 \mathrm{ft}$ into these flood-plain deposits.

\section{Glacial Deposits}

Glacial deposits in the Susquehanna River Valley near Fivemile Point range from 100 to $130 \mathrm{ft}$ thick. A surficial geology map (fig. 3) plotted from soils maps, logs of wells and test borings, and a few field observations illustrates the distribution of glacial deposits. The glacial deposits can be regarded as two types-unstratified deposits of poorly sorted material known as till, and stratified deposits of well-sorted material. Till consists primarily of locally derived sandstone, siltstone, and shale and was deposited preferentially on southfacing slopes, where the thickness averages $90 \mathrm{ft}$. In contrast, the average thickness on north-facing slopes is $22 \mathrm{ft}$ (Coates, 1973, p. 19). Till in north-south-trending valleys occurs in the form of small mounds along the valley walls. The origin of these mounds is unknown, but they may represent some type of moraine deposits later reworked by ice or water (D. R. Coates, State University of New York at Binghamton, Department of Geology, oral commun., 1986). Such mounds are fairly common in upland valleys; their occurrence near Fivemile Point in the broad Susquehanna Valley (fig. 3) is unusual.

The stratified deposits include, in upward sequence, lacustrine deposits of sand, silt and clay, outwash deposits of sand and gravel, and alluvial deposits of sand and silt. The lacustrine deposits, 10 to $70 \mathrm{ft}$ thick, underlie the outwash, which generally ranges from 10 to $30 \mathrm{ft}$ thick and covers most of the valley floor. Alluvial deposits 8 to $15 \mathrm{ft}$ thick overlie the outwash across the entire valley floor. The sand and gravel layer constitutes the principal aquifer in the area and generally provides up to $50 \mathrm{gal} / \mathrm{min}$ (gallons per minute) to pumped wells. Near Fivemile Point (fig. 3), however, the sand and gravel reaches $70 \mathrm{ft}$ in thickness and at one municipal production well supplies more than $2,000 \mathrm{gal} / \mathrm{min}$.

\section{Aquifer Description}

The aquifer at Fivemile Point consists of a 30- to 70 $\mathrm{ft}$ thickness of sand and gravel underlain by sand and silt, and is bounded laterally and beneath, in part, by till. The extent of the sand and gravel is illustrated on plate 1 and in generalized geologic sections in figure 4. Stratified deposits have been encountered below till (fig. 4, section $\mathrm{A}-\mathrm{A}^{\prime}$ ), which indicates an earlier advance of an active ice tongue in this area. The study area is near the point where a lower outlet of a proglacial lake that occupied the Susquehanna River Valley was opened, possibly during a catastrophic event. The depositional history of the area is complex, and the exact origin of the aquifer material is unknown. The presence of lacustrine material beneath the aquifer suggests that the sand and gravel may have been deposited after an erosional event that accompanied drainage of the proglacial lake through Binghamton. Alternatively, it could have been deposited in the proglacial lake as a delta from the Park Creek drainage or as ice-contact material from an active ice tongue after a readvance.

The aquifer material ranges from medium sand to cobbles more than 6 inches in diameter and contains layers of compact, silty sand and gravel that are generally less than $1 \mathrm{ft}$ thick and discontinuous. These layers are most prevalent in the upper 20 to $30 \mathrm{ft}$ of the aquifer. The horizontal hydraulic conductivity of the aquifer was estimated from an analysis of aquifer-test data by analytical methods and numerical model simulations by Yager (1986) to range from 500 to $10,000 \mathrm{ft} / \mathrm{d}$ (feet per day). Thinner deposits of sand and gravel (less than 30 $\mathrm{ft}$ ) bordering the aquifer to the south and west were estimated to have a horizontal hydraulic conductivity of 50 $\mathrm{ft} / \mathrm{d}$.

\section{Hydrologic Setting}

Ground water in the study area is in hydraulic connection with the Susquehanna River. Records of water levels and temperatures indicate that the river significantly affects ground-water flow in the aquifer at Fivemile Point.

\section{Susquehanna River}

The Susquehanna River meanders through the study area in a 400 - $\mathrm{ft}$-wide channel incised $10 \mathrm{ft}$ into the flood-plain deposits and into the underlying outwash. It drains an area of $2,232 \mathrm{mi}^{2}$ above a gaging station in Conklin, $4.5 \mathrm{mi}$ upstream from the study area. Discharge is generally greatest during snowmelt periods in the spring and is lowest just as the growing season ends in the fall. The mean daily discharge of the Susquehanna River during 1983-84 at the gaging station in Conklin, and the median mean daily discharge during 1932-80, are plotted in figure 5. Low flows in the fall are typically near $500 \mathrm{ft}^{3} / \mathrm{s}$, whereas high flows in the 


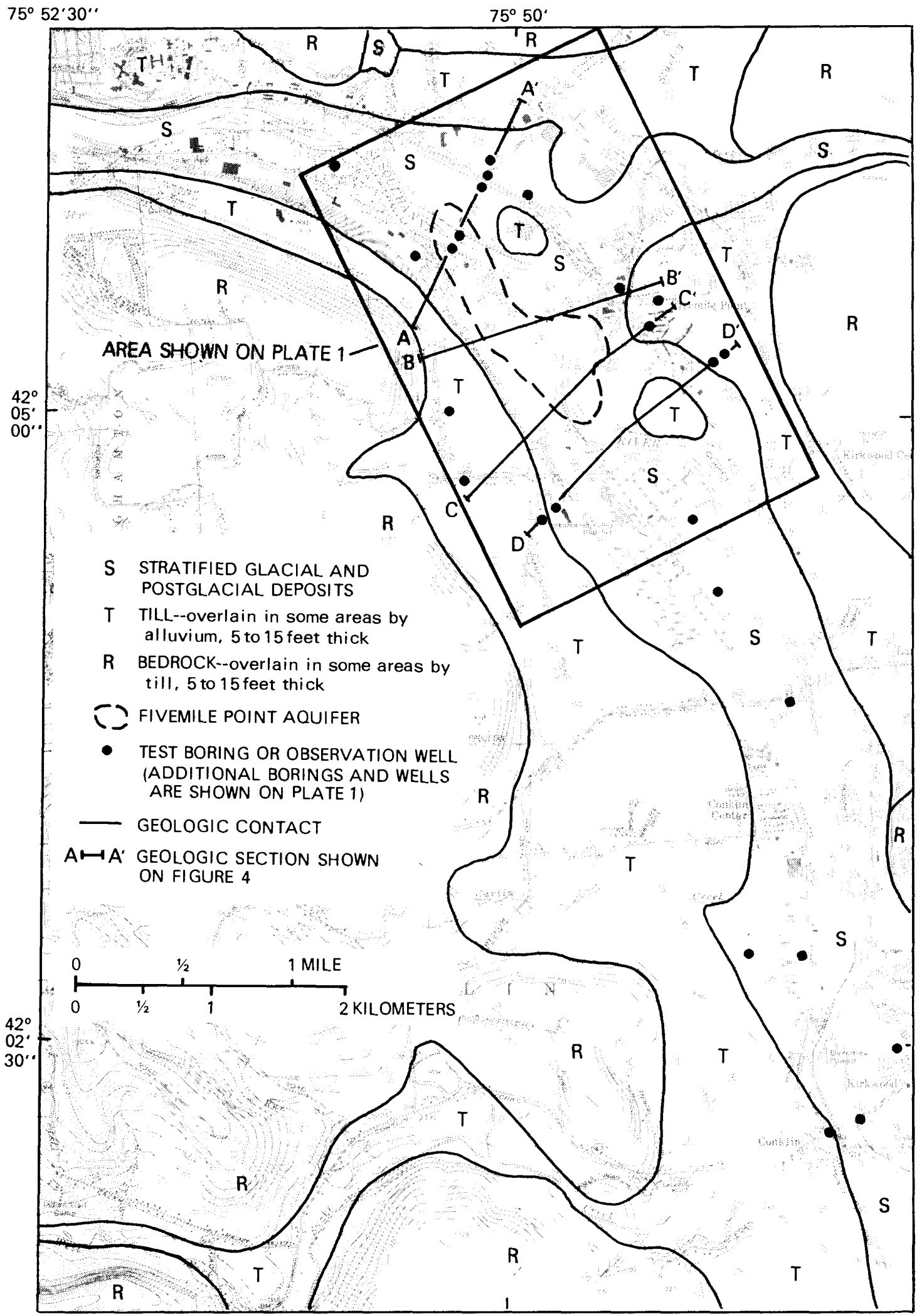

Base from New York State Department of Transportation Binghamton East, 1:24,000, 1973

Figure 3.--Surficial geology of the Susquehanna River valley near Fivemile Point. 


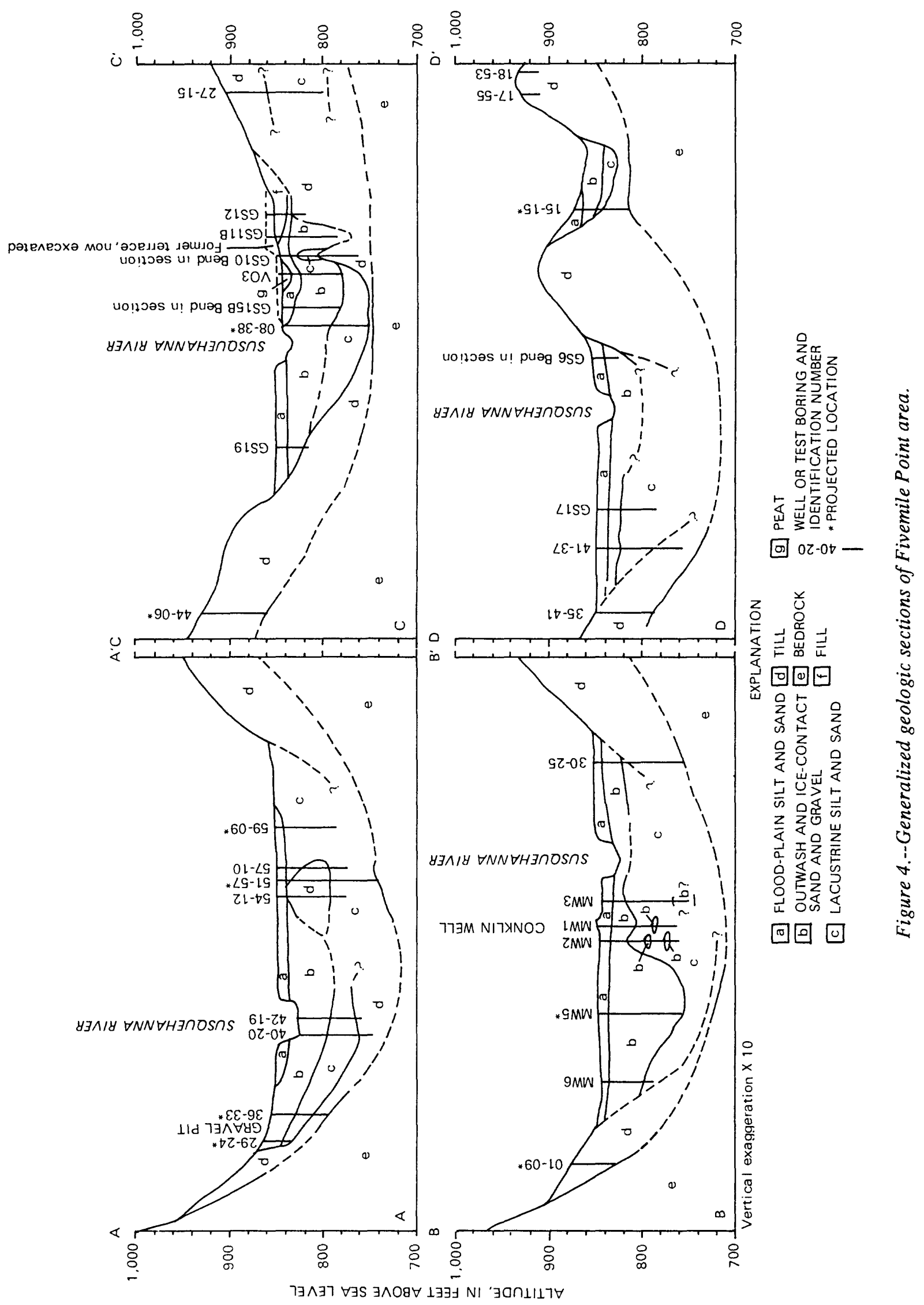




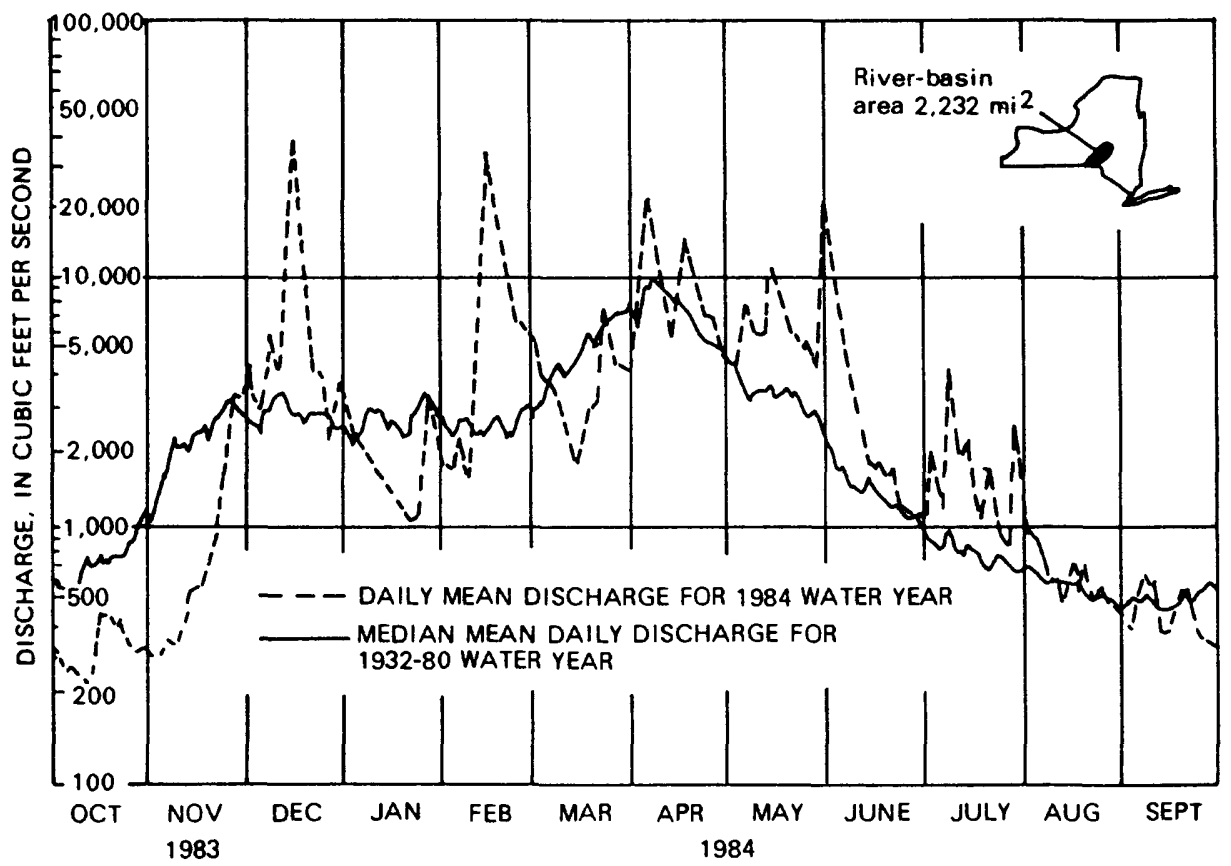

Figure 5.--Mean daily discharge of the Susquehanna River at Conklin, October 1983 through September 1984 and median mean daily discharge during 1932-80 water years.

spring may exceed $10,000 \mathrm{ft}^{3} / \mathrm{s}$ (cubic feet per second); the corresponding range in river stage is $5.5 \mathrm{ft}$. High river stages frequently cause flooding of the valley floor near the river.

\section{Ground Water}

Ground water in the sand and gravel aquifer generally flows from areas along the valley walls, where recharge from upland runoff occurs, toward the Susquehanna River and local pumping centers. Approximate directions of ground-water flow through the aquifer, based on ground-water altitudes and river stage measured in October 1984, when recharge and river discharge were near the seasonal minimum, are shown in figure 6.

Pumping from well fields in the towns of Kirkwood and Conklin has altered the natural flow pattern such that ground water previously discharged to the river is now captured by production wells. The influence of these pumping centers on the regional ground-water flow patterns is evident from the contours of the watertable in October 1984 (fig. 6). The cone of depression associated with each pumping center induces infiltration of river water into the aquifer.

The primary source of recharge to the aquifer is precipitation in the valley and uplands, although recharge also occurs through induced infiltration from the Susquehanna River and underflow from sand and gravel deposits along the upgradient boundary.

\section{Interaction Between River Water and Ground Water}

The stage of the Susquehanna River is the primary control on ground-water levels in the aquifer. Groundwater levels decline in late summer and early fall and rise in the fall and winter (fig. 7). The highest recorded ground-water levels were during peak river flows. A 3day rainfall in December 1983 caused the Susquehanna River to rise about $14 \mathrm{ft}$ and inundate part of the flood plain, during which time river water infiltrated into the aquifer and caused ground-water levels to rise $6 \mathrm{ft}$. These inundations are a significant source of recharge to the aquifer. The rise and decline of ground-water levels during this period (fig. 7) indicates that the aquifer system near the well field responds within a few days to changes in river stage.

Ground-water temperature. Vertical profiles of ground-water temperatures measured in observation wells monthly during the study indicate the effect of infiltrating river water on ground-water temperatures. Ground-water temperatures in areas not influenced by the river change gradually throughout the year, and the extremes do not differ by more than $3^{\circ} \mathrm{C}$. In contrast, ground water in areas receiving infiltration from the river have a temperature range of more than $16^{\circ} \mathrm{C}$.

The seasonal variation in temperature with depth in observation well GP1B (location shown in fig. 9) is shown in figure 8 along with discharge and temperature recorded in the Susquehanna River. Maximum ground- 


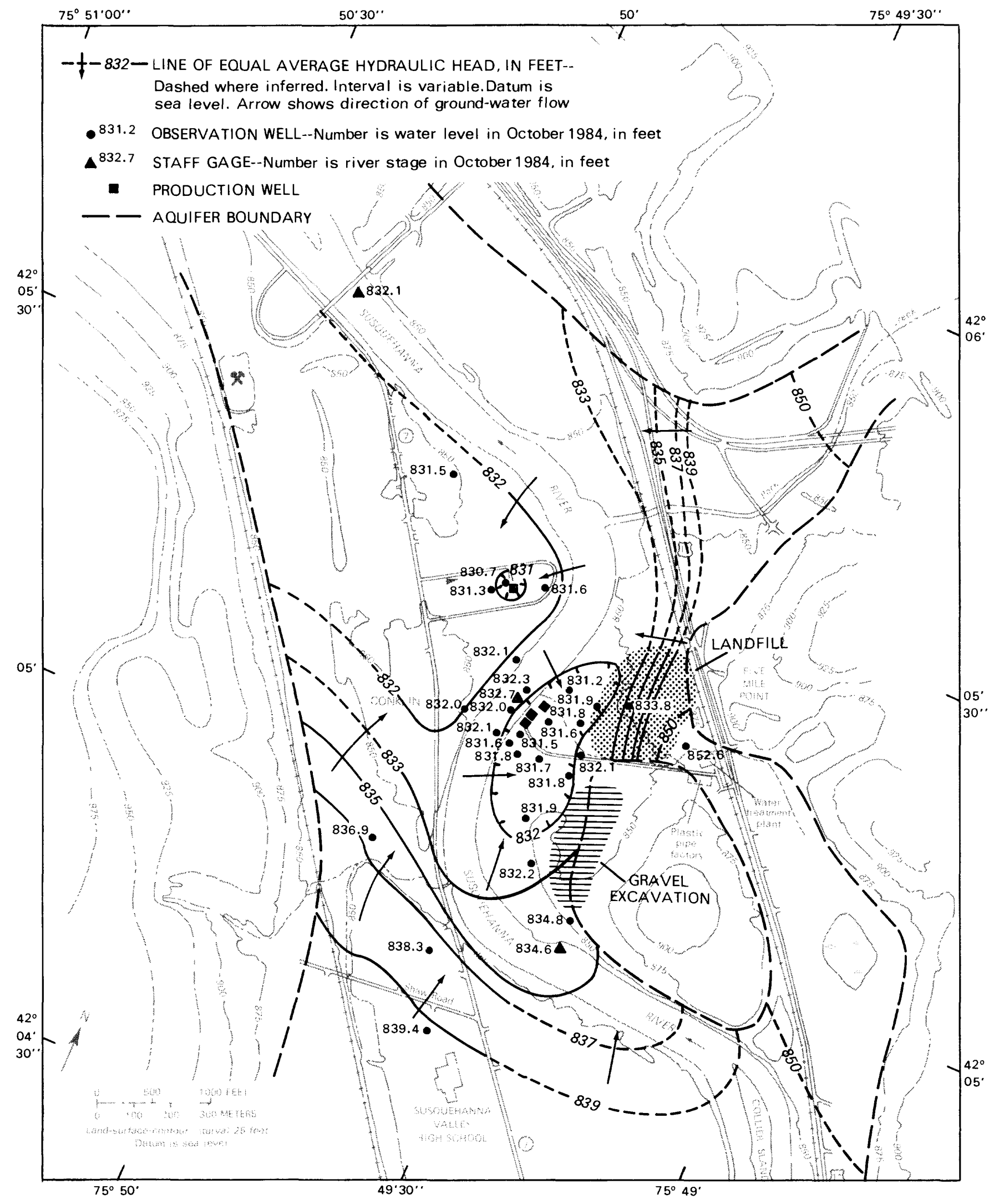

Base from Susquehanna River Basin Commissıon. 1974

Figure 6.--Average hydraulic head and direction of ground-water flow in Fivemile Point area in October 1984. 


\section{Figure 7.}

Graph showing stage of
Susquehanna River at Conklin
and ground-water levels in
observation well VO3 $(250 \mathrm{ft}$
from river), October 1983
through November 1984.

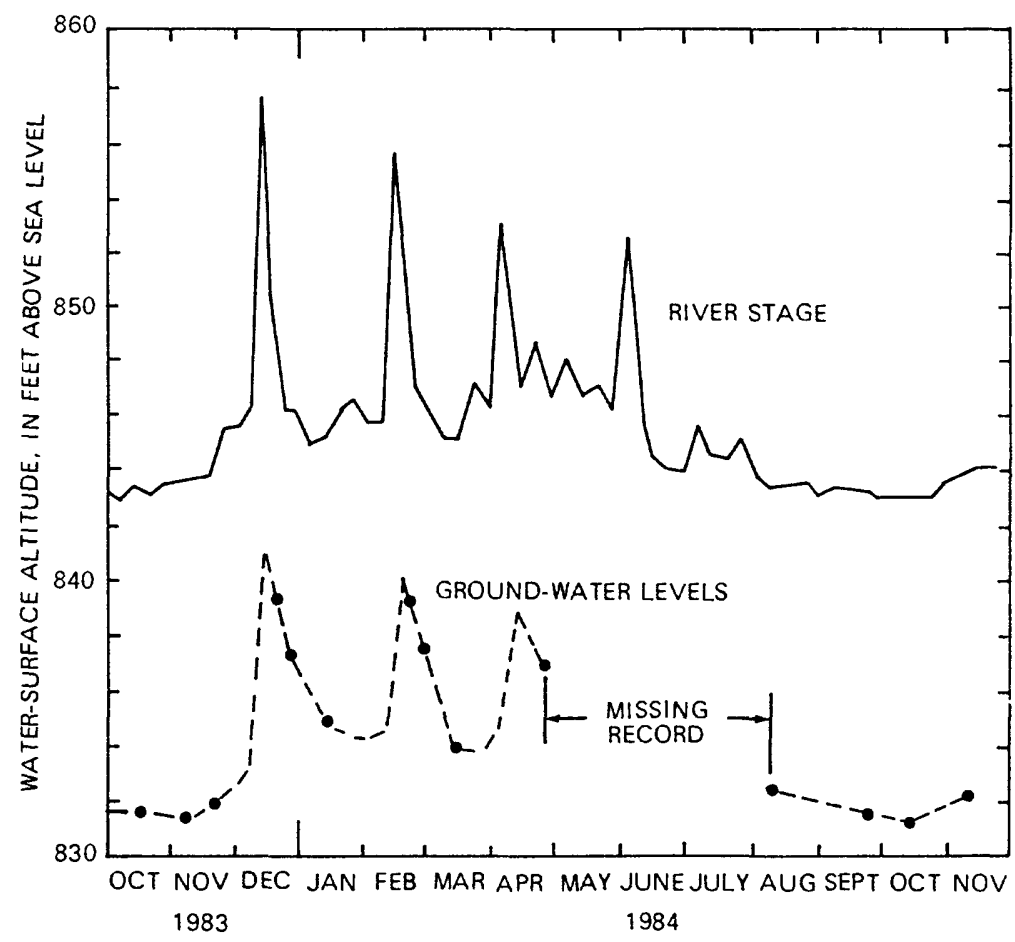

water temperatures of more than $20^{\circ} \mathrm{C}$ were recorded in September-October 1984 and 1985, and minimum temperatures of less than $4^{\circ} \mathrm{C}$ were recorded in April-May 1985. This large range is caused by the infiltration of river water, which warms the aquifer during late summer and fall and cools it during winter and spring. The largest temperature range $\left(4^{\circ} \mathrm{C}\right.$ to $\left.20^{\circ} \mathrm{C}\right)$ was recorded 15 to $20 \mathrm{ft}$ below the riverbed-an area that probably lies along a flow path from the river to production well GP1 (Yager, 1986, fig. 12). Comparison of temperature profiles from other observation wells near the Kirkwood well field indicate that the highest rate of river infiltration is in a small area near the production wells.

Riverbed characteristics. The channel of the Susquehanna River contains alternating sets of pools and riffles that are characteristic of gravelbed streams (Leopold and others, 1964, p. 203). The difference in riverbed altitude between the pools and riffles in the Kirkwood area is 4 to $5 \mathrm{ft}$. Therefore, the depth of bed transport must be at least $5 \mathrm{ft}$ if the riffles are bars migrating along the channel. Several test borings on channel bars or on the flood plain of the Susquehanna River downstream from its confluence with the Chenango River at Binghamton penetrated 8 to $22 \mathrm{ft}$ of noncalcareous gravel near channel grade that contains organic fragments and is inferred to be channel-bedload alluvium (A. D. Randall, U.S. Geological Survey, written commun., 1987).

Samples of material from 1 to $4 \mathrm{ft}$ beneath the riverbed were obtained with a split-spoon sampler and a portable driving assembly at four sites near Fivemile Point. The sites were located on a riffle within $30 \mathrm{ft}$ of the riverbank on the outside of a meander bend. One to three layers of compact, silty sand and gravel that would restrict the vertical movement of river water into the aquifer were encountered at each location. The layers are less than $1 \mathrm{ft}$ thick and separated by deposits of more uniform sand and gravel. Fine sand and silt $2 \mathrm{ft}$ thick was encountered at one location; this may represent deposition in a former pool of the riverbed. The layers of silty sand and gravel were similar to those discovered in the aquifer material $50 \mathrm{ft}$ lower than the riverbed, which suggests that these layers may be glacial deposits exposed by incision of the river channel during postglacial times, rather than alluvial deposits of the river itself.

The vertical hydraulic conductivity of four samples of silty sand and gravel and one of fine sand and silt collected with a Shelby tube was estimated through constant-head, triaxial permeameter tests. The geometric mean value for the five tests was $10^{-3} \mathrm{ft} / \mathrm{d}$; the coefficient of variation of logarithms of the conductivity values was 7 percent, indicating the range of measured values was relatively small. The organic content of the samples, measured as volatile solids, ranged from 1.5 to 3.7 percent.

Vertical hydraulic-conductivity values determined by laboratory tests are not representative of the riverbed deposits as a whole because only the silty sand and gravel layers of low permeability within the riffles were tinuous; thus, the more permeable materials beneath the riverbed provide continuous pathways for infiltration. Therefore, the effective vertical hydraulic conductivity of the riverbed deposits is probably greater than $10^{-3} \mathrm{ft} / \mathrm{d}$. selected for analysis. These layers are probably discon- 


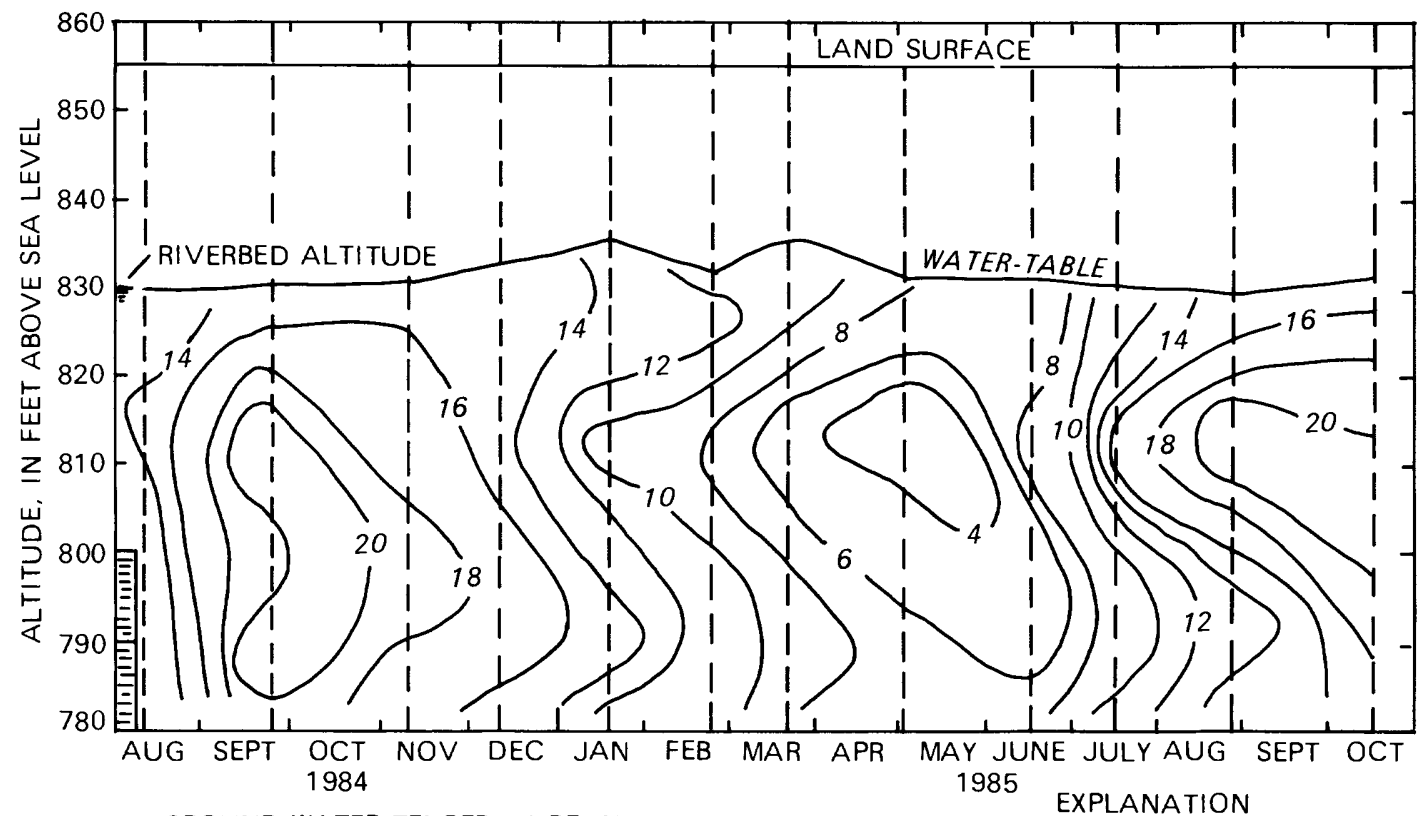
A. GROUND-WATER TEMPERATURE IN OBSERVATION WELL GP1B
- 8- LINE OF EQUAL TEMPERATURE, IN DEGREES CELSIUS. DASHED LINE INDICATES DATE OF MEASUREMENT SCREENED INTERVAL OF PRODUCTION WELL

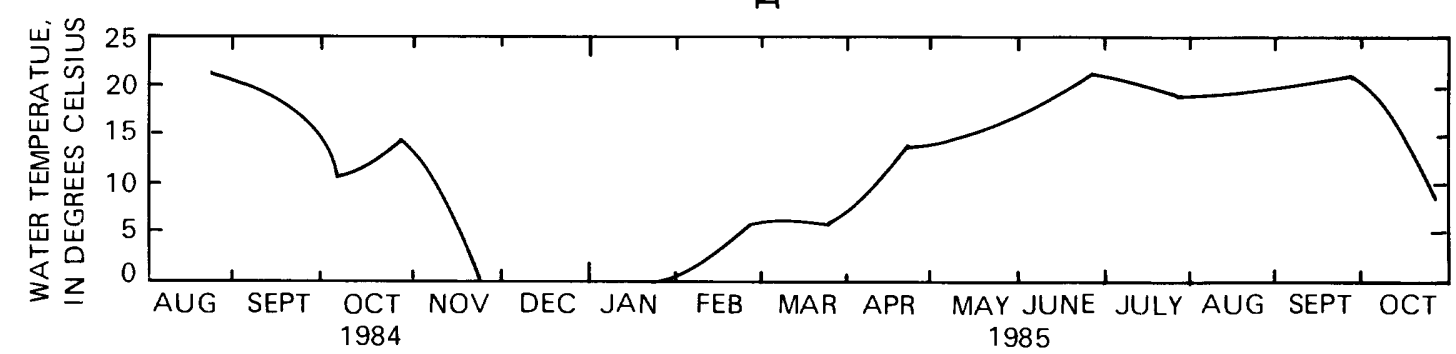

B. WATER TEMPERATURE OF SUSQUEHANNA RIVER AT CONKLIN, NEW YORK

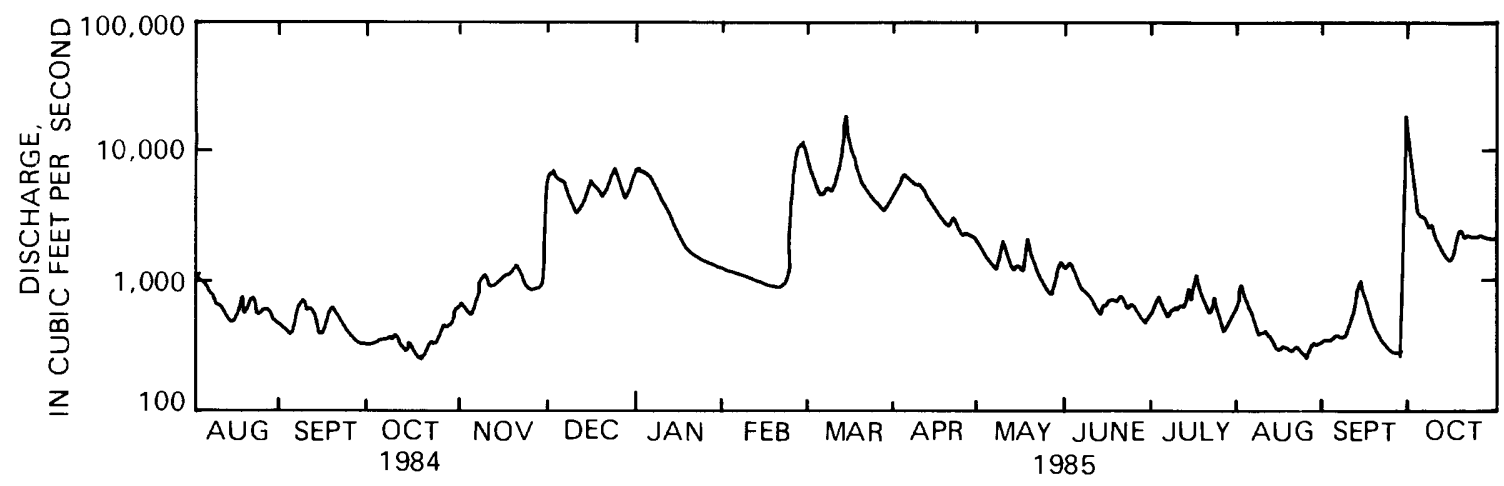

C. DISCHARGE OF SUSOUEHANNA RIVER AT CONKLIN, NEW YORK

Figure 8.--Seasonal variation in water temperature and river discharges, August 1984 to October 1985:

A. Ground-water temperature in well GP1B ( $50 \mathrm{ft}$ from river).

$B$. Temperature of the Susquehanna River at Conklin.

C. Discharge of the Susquehanna River at Conklin. 


\section{ESTIMATION OF HYDRAULIC CONDUCTIVITY OF}

RIVERBED AND AQUIFER

\section{Ground-Water Flow Model}

A finite-difference model developed for the U.S. Geological Survey by McDonald and Harbaugh (1988) to simulate ground-water flow in three dimensions was used to quantify hydraulic properties of the riverbed and aquifer material and to estimate the quantity of river water entering the aquifer in response to pumping. The model solves a finite-difference approximation to the partial-differential equation that describes the movement of ground water through porous material, given in McDonald and Harbaugh (1988):

$$
\begin{aligned}
& \frac{\partial\left(K_{x x} \frac{\partial h}{\partial x}+\frac{\partial}{\partial y}\left(K_{y y} \frac{\partial h)}{\partial y}\right.\right.}{+\frac{\partial\left(K_{x x} \frac{\partial h}{\partial x}-W\right.}{\partial z}=S_{s} \frac{\partial h}{\partial t}}
\end{aligned}
$$

where:

$$
\begin{aligned}
& \mathrm{x}, \mathrm{y}, \text { and } \mathrm{z} \text { are cartesian coordinates }(\mathrm{L}) \text { aligned } \\
& h \text { is the hydraulic head (L); } \\
& \mathrm{W} \text { is a volumetric flux per unit volume } \\
& S_{s} \text { is specific storage of the porous } \\
& \text { material }\left(\mathrm{L}^{-1}\right) \text {; and } \\
& t \text { is time }(t) \text {. }
\end{aligned}
$$

The hydraulic-head distribution computed by the model was then used to estimate the direction and rate of ground-water flow between points within the aquifer. The flow paths estimated from model output were then used to delineate the catchment areas that contribute ground water to the well fields and quantify sources of recharge to the wells (Yager, 1986).

\section{Model Grid and Layering}

The sand and gravel aquifer is represented by a grid that divides the aquifer-surface area into 50 rows and 42 columns (pl.1B and fig. 9) and consists of four layers (fig. 10). The active area of the model represents about $0.68 \mathrm{mi}^{2}$. The grid was designed to simulate the steep hydraulic gradient near the pumping centers in detail while minimizing the total number of blocks in the model.
The vertical layering in the model was specified to reflect the general composition of the aquifer material and the placement of the screens in the production and observation wells (fig. 10). Model layers 1 and 2 represented the upper $20 \mathrm{ft}$ of the aquifer, in which layers of silty sand and gravel of low permeability are prevalent. Layers 3 and 4 represented the more uniform lower 30 $\mathrm{ft}$ of the aquifer; layer 3 was chosen to be $20 \mathrm{ft}$ thick to correspond to the depth of the production well screens in the Kirkwood well field, and layer 4 was $10 \mathrm{ft}$ thick. The screen depth of 27 observation wells monitored during an aquifer test at the Kirkwood well field corresponded to either layer 1,2 or 3 . Local variations in saturated thickness or type of material within a layer were accounted for by the distribution of transmissivity values within the layer.

\section{Boundary Conditions}

The upper boundary of the model was specified as a constant-flow boundary representing recharge from precipitation on the valley floor and recharge along valley walls from upland runoff (pl. 1B). The contact between the stratified drift and surrounding till was assumed to be a no-flow boundary because the hydraulic conductivity of the till is estimated to be $10^{6}$ times lower than that of the sand and gravel. A ground-water budget developed by Yager (1986) indicates that upward leakage into the aquifer through the till is negligible compared to recharge from precipitation and runoff. Lateral boundaries across the valley where ground water flows to or from the model area are specified-head boundaries. Locations of lateral no-flow and specified-head boundaries are shown on plate 1B.

Flow across the specified-head boundary is represented by the following equation:

$$
\mathrm{Q}=\mathrm{C}(\mathrm{H}-\mathrm{h})
$$

where: $Q$ is the rate at which water enters or is discharged at a block along the boundary $\left(\mathrm{L}^{3} \mathrm{t}^{-1}\right)$;

$\mathrm{C}$ is the horizontal conductance of the block $\left(\mathrm{L}^{2} \mathrm{t}^{-1}\right)$;

$\mathrm{H}$ is the head of the boundary; and

$h$ is the head at the center of the block.

The conductance, $\mathrm{C}$, for each block along the boundary is given by:

$$
C=\frac{K A}{1}
$$


where: $\quad \mathrm{K}$ is the horizontal hydraulic conductivity of the block $\left(\mathrm{Lt}^{-1}\right)$; (the term "hydraulic conductivity" used hereafter refers to horizontal hydraulic conductivity)

$A$ is the cross-sectional flow area $\left(\mathrm{L}^{2}\right)$; and

1 is the flow length between the center of the block and the model boundary (L).
Infiltration of river water into the aquifer and discharge of ground water to the river were simulated as leakage through a semiconfining layer representing the riverbed deposits. Riverbed altitudes were taken from channel cross sections (Yager, 1986, pl. 1) measured by the U.S. Army Corps of Engineers (1982, pl. A-2). River stages were determined from these cross sections and adjusted in accordance with the measured stage at staff gage R2 (pl. 1).

Flow through the riverbed is also simulated through equation 2, where the conductance $(C)$ is defined by

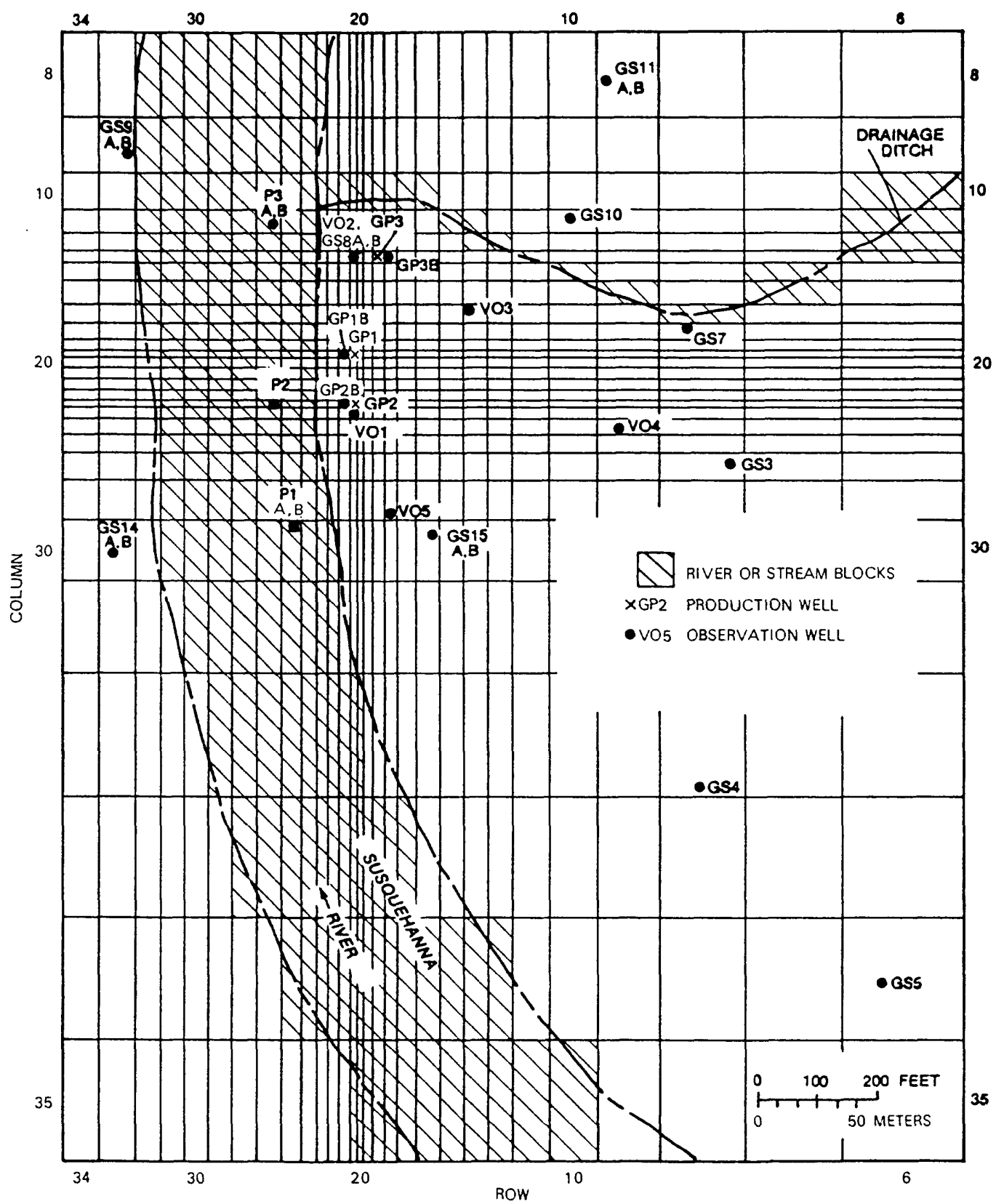

Figure 9.--Detail of model grid near Kirkwood well field. 


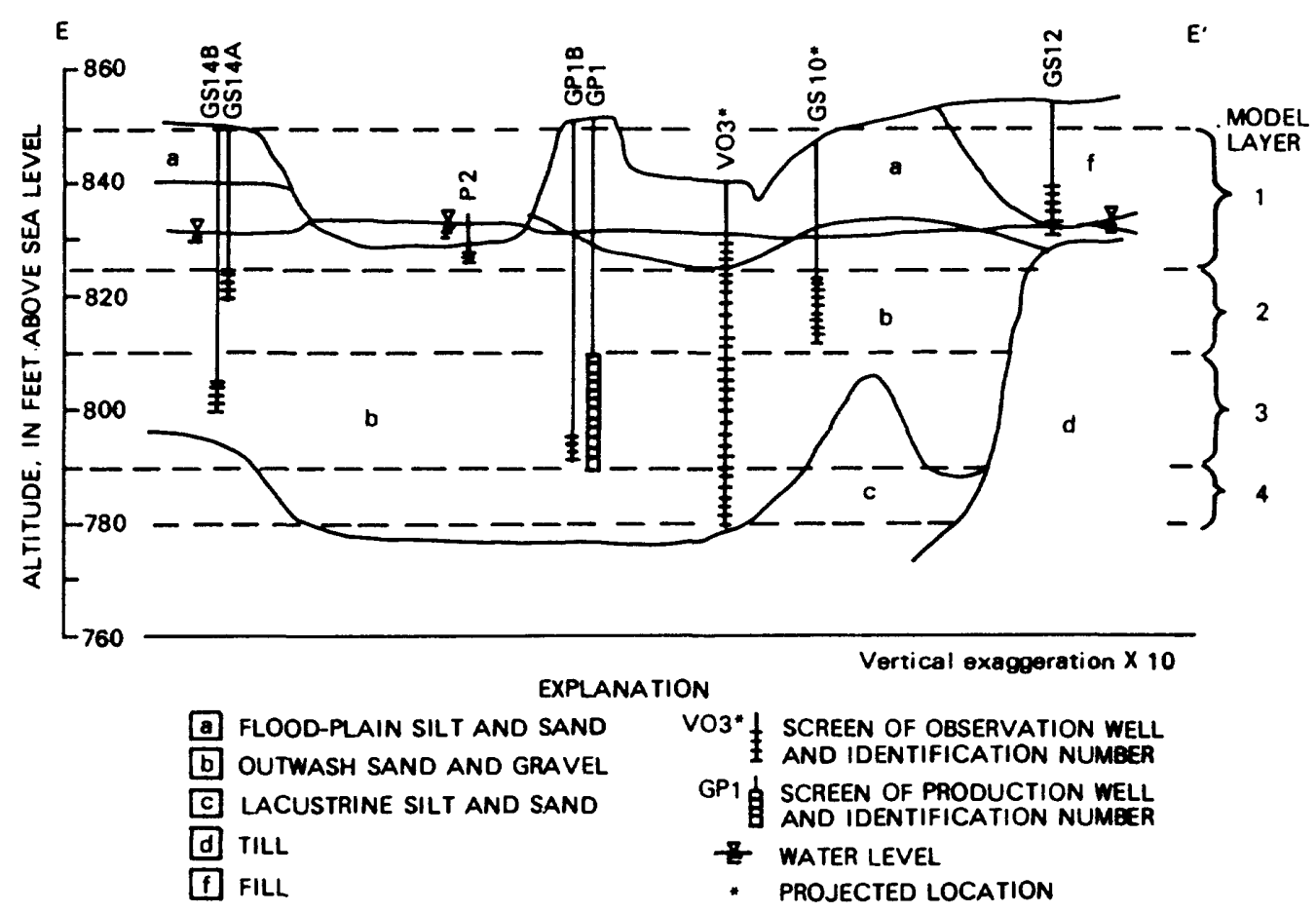

Figure 10.--Schematic vertical profile of aquifer along section E-E' showing layers and boundaries used in model. (Location is shown in fig. 12.)

equation 3 with the horizontal hydraulic conductivity replaced by the vertical hydraulic conductivity of the riverbed, $\mathrm{Kr}$, and the flow length, 1 , defined as the thickness of the riverbed. Riverbed conductance per unit area was assumed to be uniform along the reach and was estimated through model calibration to be 0.1 $\mathrm{d}^{-1}$ (Yager, 1986). As explained earlier (p. 10), the thickness of riverbed deposits along the Susquehanna River may exceed $5 \mathrm{ft}$. Because the thickness of the riverbed material at Kirkwood is unknown, an arbitrary value of $1 \mathrm{ft}$ was assumed, and the vertical hydraulic conductivity of the riverbed was computed to be 0.1 $\mathrm{ft} / \mathrm{d}$. Thus, if the true thickness of riverbed deposits is $5 \mathrm{ft}$, the vertical hydraulic conductivity would be 0.5 $\mathrm{ft} / \mathrm{d}$.

\section{Hydraulic Properties}

Blocks representing sand and gravel or sand and silt deposits were assigned horizontal and vertical hydraulic conductivity and storage values. Hydraulic conductivity was assumed to be laterally isotropic. Initial estimates of hydraulic properties were obtained from time-vs-drawdown data recorded during three aquifer tests at the Kirkwood well field and from slugand-bail tests conducted at five piezometers (Yager, 1986). The general characteristics of hydraulic properties obtained from trial-and-error calibration are described in the following paragraphs.
Hydraulic conductivity. Hydraulic conductivity of the sand and gravel aquifer was distributed over five ranges between 500 and $10,000 \mathrm{ft} / \mathrm{d}$ that were assigned to zones in each of the four model layers. These values were based on analysis of drawdown data from aquifer tests by analytical methods and model calibration. Transmissivity zones were selected to represent lateral variations in aquifer thickness and were delineated to correspond to local variations in hydraulic gradient and distribution of measured drawdowns during the aquifer test. Transmissivity values in each zone were then divided by the thickness of the corresponding model layer to obtain the hydraulic conductivity zones illustrated in figure 11. Hydraulic conductivity of deposits bordering the aquifer was distributed over two ranges between 50 and $5 \mathrm{ft} / \mathrm{d}$. Hydraulic conductivity of sand and silt deposits to the east of the aquifer was assumed from results of slug and bail tests to be $5 \mathrm{ft} / \mathrm{d}$; that of material in the landfill adjacent to the aquifer and in an area of sand and gravel less than $30 \mathrm{ft}$ thick in Conklin was estimated through calibration to be $50 \mathrm{ft} / \mathrm{d}$ (fig. 11A).

The highest hydraulic conductivity value $(10,000$ $\mathrm{ft} / \mathrm{d}$ in zone 7 of layer 3 , fig. 11C) corresponds to a layer of sand and gravel tapped by the Kirkwood production well GP1. Hydraulic conductivity near production well GP2 (zone 3 of layer 3, fig. 11C) was decreased to a value of $500 \mathrm{ft} / \mathrm{d}$ to simulate $6.7 \mathrm{ft}$ of drawdown measured $20 \mathrm{ft}$ from GP2 when operating at $1,000 \mathrm{gal} / \mathrm{min}$; 
$2.3 \mathrm{ft}$ of drawdown was measured $20 \mathrm{ft}$ from GP1, which was pumped at the same rate. Hydraulic conductivity in layers 2 and 4 (figs. 11B, 11D) near the Kirkwood well field ranged from 500 to $2,000 \mathrm{ft} / \mathrm{d}$, close to the values obtained from the aquifer-test analysis. Hydraulic conductivity of layer 1 ranged from less than 10 to $500 \mathrm{ft} / \mathrm{d}$.

Anisotropy. The horizontal hydraulic conductivity of the sand and gravel aquifer is much greater than its vertical hydraulic conductivity because silty sand and gravel lenses restrict the vertical movement of water. The ratio of horizontal to vertical hydraulic conductivity, hereafter referred to as anisotropy, was estimated to be 250:1 in layers 1 and 2 (upper part of the aquifer) and 125:1 in layers 3 and 4 (the lower part).

Vertical leakage of ground water between adjacent model layers was calculated from:
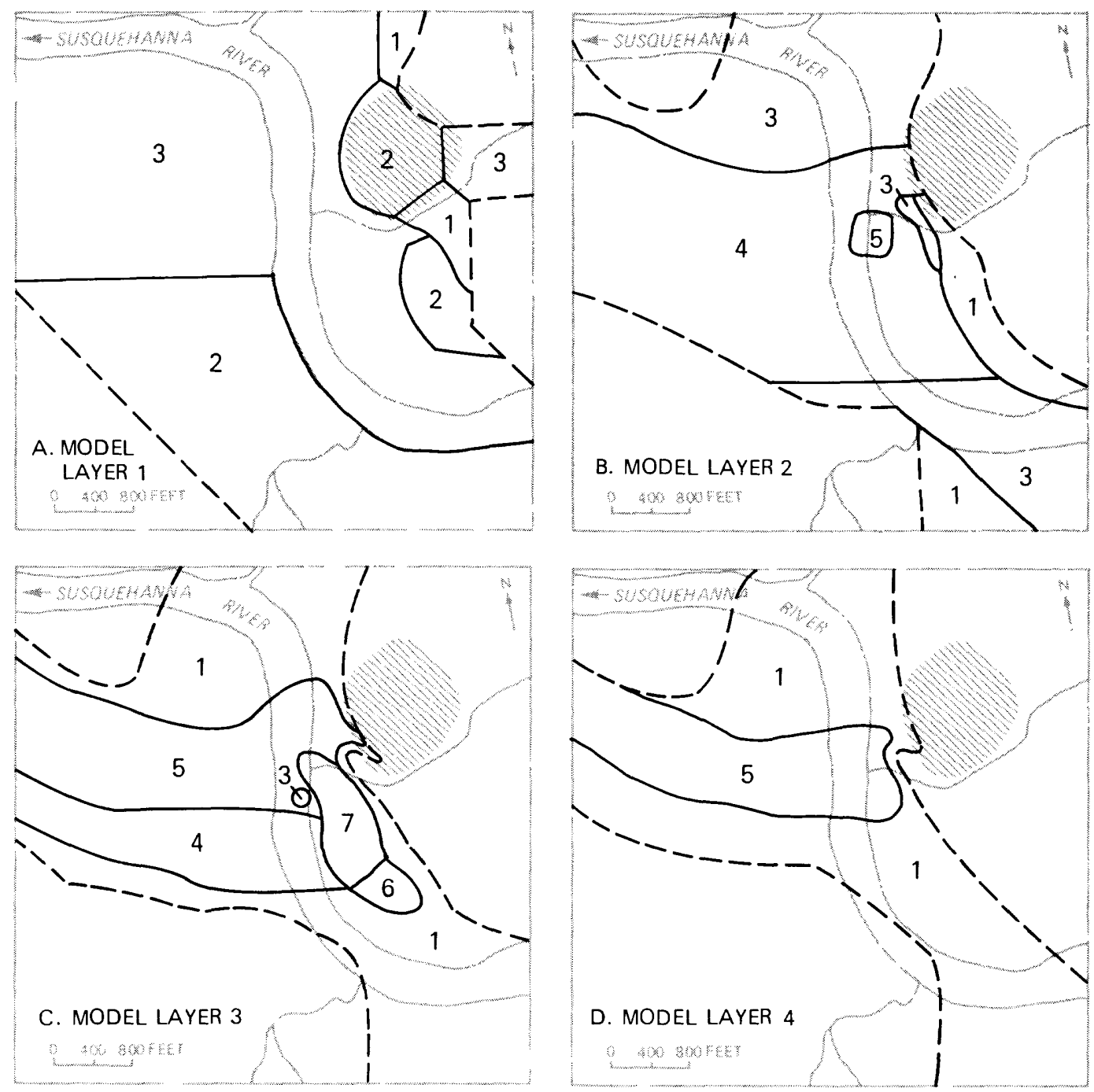

EXPLANATION

HYDRAULIC CONDUCTIVITY(feet per day)

$$
\begin{array}{ll}
1-\text { less than } 10 & 5-2,000 \\
2-50 & 6-5,000 \\
3-500 & 7-10,000 \\
4-1,000 &
\end{array}
$$

Figure 11.-- Distribution of hydraulic conductivity values in model. A. Layer 1 .

B. Layer 2. C. Layer 3. D. Layer 4. 


$$
\mathrm{Q}_{\mathrm{V}}=\mathrm{C}_{\mathrm{T}} \Delta \mathrm{h}
$$

where: $Q_{v}$ is vertical flow $\left(\mathrm{L}^{3} \mathrm{t}^{-1}\right)$,

$\Delta h$ is the difference in head between the center of upper and lower blocks $(\mathrm{L})$, and

$\mathrm{C}_{\mathrm{T}}$ is the hydraulic conductance between model layers, defined as:

$$
\frac{1}{\mathrm{C}_{\mathrm{T}}}=\Sigma \frac{1}{\mathrm{C}_{\mathrm{i}}} \quad \mathrm{i}=1,2
$$

where: $C_{i}$ is the vertical hydraulic conductance within a layer defined as:

$$
\mathrm{C}_{\mathrm{i}}=\frac{\mathrm{Kv}_{\mathrm{i}} \mathrm{A}}{\mathrm{L}_{\mathrm{i}}}
$$

where: $\mathrm{Kv}_{\mathrm{i}}$ is the vertical hydraulic conductivity

$$
\begin{aligned}
& \text { of layer } \mathrm{i}\left(\mathrm{LT}^{-1}\right) \text {; } \\
& \mathrm{A} \text { is the area of the block }\left(\mathrm{L}^{2}\right) \text {; and } \\
& \mathrm{L}_{\mathrm{i}} \text { is one-half the thickness of layer } \mathrm{i}(\mathrm{L}) \text {. }
\end{aligned}
$$

Storage coefficient and specific yield.

All layers in the model except layer 1 are confined by the overlying model layers, and a storage coefficient of $10^{-3}$ was specified for each on the basis of results of the aquifertest analysis. Layer 1 represents the upper part of the sand and gravel, which is unconfined except where it is overlain by riverbed deposits. (See pl. 1B.) A specific yield of 0.25 was specified for the unconfined areas in layer 1 , and a storage coefficient of $10^{-3}$ was used for the area beneath the river.

\section{Model Calibration}

The model was calibrated through simulation of transient conditions during a 23-hour aquifer test performed at the Kirkwood well field in October 1984. Water levels recorded in 27 observation wells were compared with the drawdown distribution obtained in the transient-state simulation to assess the model's ability to represent the ground-water system.

Transient-state simulations represented a period of 23 hours when wells GP1 and GP2 (fig. 9) were each pumped at a rate of $1,000 \mathrm{gal} / \mathrm{min}$ at the end of an 8 hour recovery period that followed a 24 -hour period of production-well operation. Application of the method of Neuman (1975) indicates that water levels recovered to more than 90 percent of the prepumping levels in most of the wells, and that residual drawdown in wells closest to the pumped well $(20 \mathrm{ft})$ was less than $0.1 \mathrm{ft}$ at the beginning of the aquifer test.
Simulated drawdowns were compared with measured drawdowns in 27 observation wells after 23 hours of pumping (table 1) when the expansion of the drawdown cone had been slowed by the delayed yield described by Neuman (1975). The large number of observation wells used provided good definition of the drawdown distribution, but the measurement of drawdowns over time could be made in only a few wells. Therefore, the model was calibrated to the position of the drawdown cone recorded 23 hours after the start of the test. Simulated and observed drawdowns were compared directly through the principle of superposition (Reilly and others, 1984), and the initial heads throughout the aquifer system and the recharge rate were

\begin{tabular}{|c|c|c|c|c|}
\hline $\begin{array}{c}\text { Observation } \\
\text { well }\end{array}$ & $\begin{array}{c}\text { Model } \\
\text { layer }\end{array}$ & $\begin{array}{l}\text { Observed } \\
\text { values }\end{array}$ & $\begin{array}{c}\text { Computed } \\
\text { values }\end{array}$ & $\begin{array}{l}\text { Percent }{ }^{1} \\
\text { difference }\end{array}$ \\
\hline GS3 & 2 & 1.37 & 1.39 & 1.4 \\
\hline GS4 & 3 & 1.42 & 1.37 & -3.9 \\
\hline GS5 & 2 & .74 & .63 & -14.9 \\
\hline GS6 & 1 & .00 & 0.00 & 0.0 \\
\hline GS7 & 2 & 1.18 & 1.12 & -5.1 \\
\hline GS9A & 2 & .85 & .89 & 4.7 \\
\hline GS9B & 3 & 1.23 & 1.11 & -9.8 \\
\hline GS10 & 2 & 1.56 & 1.15 & -26.3 \\
\hline GS11A & 2 & 1.20 & .90 & -25.0 \\
\hline GS11B & 3 & 1.08 & 1.15 & 6.5 \\
\hline GS12 & 1 & .00 & .01 & .0 \\
\hline GS13 & 1 & .00 & .00 & .0 \\
\hline GS14A & 2 & 1.16 & .80 & -31.0 \\
\hline GS14B & 3 & 1.16 & .99 & -14.7 \\
\hline GS15A & 2 & 1.07 & 1.33 & 24.3 \\
\hline GS15B & 3 & 1.63 & 1.86 & 14.1 \\
\hline GS16A & 2 & 1.49 & 1.20 & -19.5 \\
\hline GS16B & 3 & 1.53 & 1.59 & 3.9 \\
\hline GS17 & 1 & .00 & .00 & .0 \\
\hline GS18 & 1 & .00 & .00 & .0 \\
\hline GS19 & 1 & .00 & .00 & .0 \\
\hline GP1B & 3 & 2.34 & 2.65 & 13.2 \\
\hline GP2B & 3 & 6.73 & 3.95 & -41.3 \\
\hline P1B & 1 & 1.30 & 1.06 & -18.5 \\
\hline $\mathrm{P} 2$ & 1 & 1.26 & 1.02 & -19.0 \\
\hline P3A & 1 & 1.06 & 1.01 & -4.7 \\
\hline P3E & 3 & 1.30 & 1.62 & 24.6 \\
\hline \multicolumn{4}{|c|}{ RMS difference } & 17 percent \\
\hline
\end{tabular}
assumed to be zero.

Table 1.--Drawdowns after 23 hours of pumping computed by transient-state simulation of aquifer test in October 1984 at Kirkwood well field.

[All values are in feet. Locations are shown on pl. 1.]

${ }^{1}$ Based on observed drawdown

The hydraulic properties of the aquifer were adjusted by trial and error during model calibration. Improvements in model results were identified (1) 
through comparison of differences (residuals) between the computed and observed drawdowns, and (2) through comparison of the sum of squared errors (SSE), defined as:

$$
\mathrm{SSE}=\Sigma(\mathrm{AE})^{2}
$$

where: $\mathrm{AE}$ is the absolute error (observed value predicted value) for each observation well,

and (3) the root-mean-square (RMS) difference, defined as:

$$
\mathrm{RMS}={\frac{\Sigma(\mathrm{AE} / \mathrm{obs})^{2}}{\mathrm{n}}}^{1 / 2}
$$

where: $\quad n$ is the number of observation wells, and

obs is the observed value.
The RMS difference in computed drawdowns was 17 percent, and the maximum difference between computed and observed drawdowns was $-2.8 \mathrm{ft}$ at well GP2B (fig. 9). Absolute error was $0.3 \mathrm{ft}$ or less at all but six wells.

Computed drawdowns corresponded closely to the drawdowns measured in observation wells. The distributions of computed drawdown in layers 2 and 3 are shown in figures $12 \mathrm{~A}$ and $12 \mathrm{~B}$, respectively; vertical profiles of the computed drawdown distribution along cross sections E-E' and F-F' are presented in figure 13. Measured drawdowns of at least $1.0 \mathrm{ft}$ extended more than $400 \mathrm{ft}$ laterally beneath the Susquehanna River west of the well field and more than $800 \mathrm{ft}$ toward the south. The smaller drawdowns across the river indicate that the river acts as a leaky recharge boundary that supplies water to the well field.

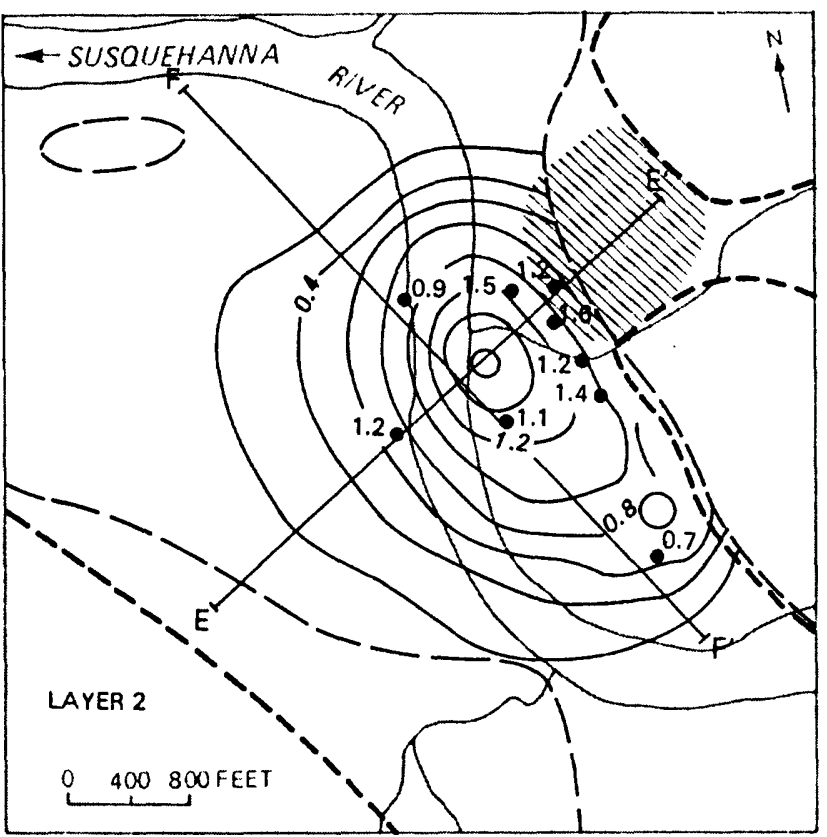

EXPLANATION

\begin{tabular}{|c|c|}
\hline - & TILL BOUNDARY \\
\hline & CONSTRUCTION LANDFILL \\
\hline - & $\begin{array}{l}\text { LINE OF EQUAL DRAWDOWN } \\
\text { SIMULATED BY FLOW MODEL, } \\
\text { CONTOUR INTERVAL } 0.2 \text { FEET }\end{array}$ \\
\hline
\end{tabular}

- - AQUIFER BOUNDARY IN LAYER 1

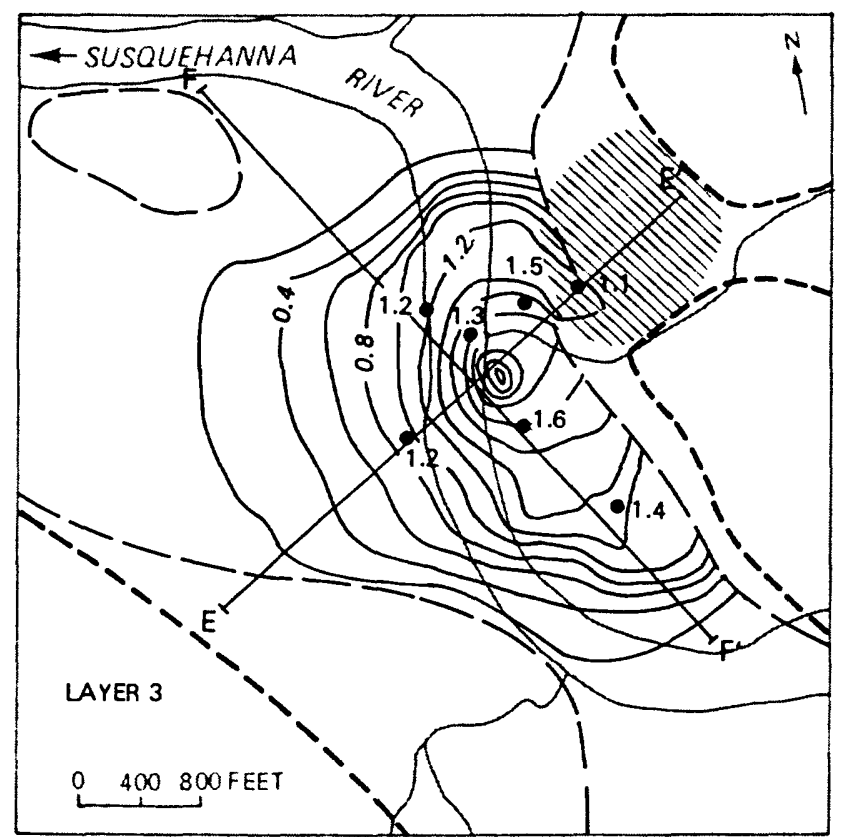

- 1.2 OBSERVATION WELL, NUMBER IS MEASURED DRAWDOWN IN FEET

E—E' GEOLOGIC SECTION

Figure 12.-- Distribution of drawdowns in model layers 2 and 3 computed by transient-state simulation of October 1984 aquifer test. 


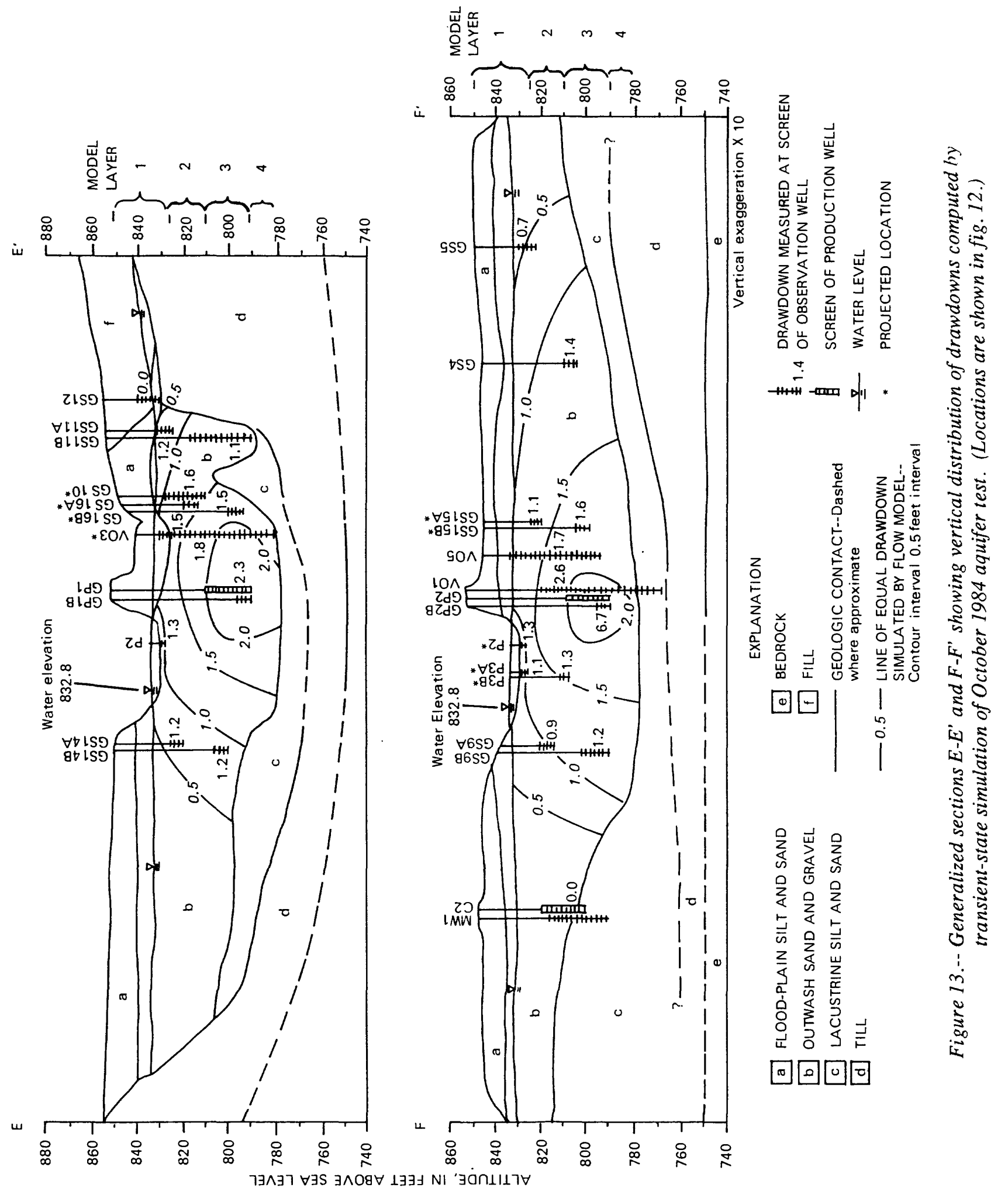


A graph of residuals in relation to computed drawdowns (fig. 14) shows that large drawdowns are overestimated and small drawdowns are underestimated. One exception is at observation well GP2B, where a large drawdown of $6.7 \mathrm{ft}$ was underestimated. This well is in an area near production well GP2, where the estimated hydraulic conductivity is much lower than that of the surrounding area. The lateral distribution of residuals in the upper and lower aquifers (fig. 15) shows that drawdowns in the upper part of the aquifer (layers 1 and
2) are generally underestimated, whereas those in the lower part (layers 3 and 4) are overestimated. This graphical analysis indicates that the residuals are correlated and that the drawdowns computed by the calibrated model are biased.

The estimated values for the hydraulic properties of the aquifer material yield a relatively low residual in terms of the RMS difference. The bias mentioned previously indicates that some of these values or the pattern of their distribution is incorrect, however. An alterna-

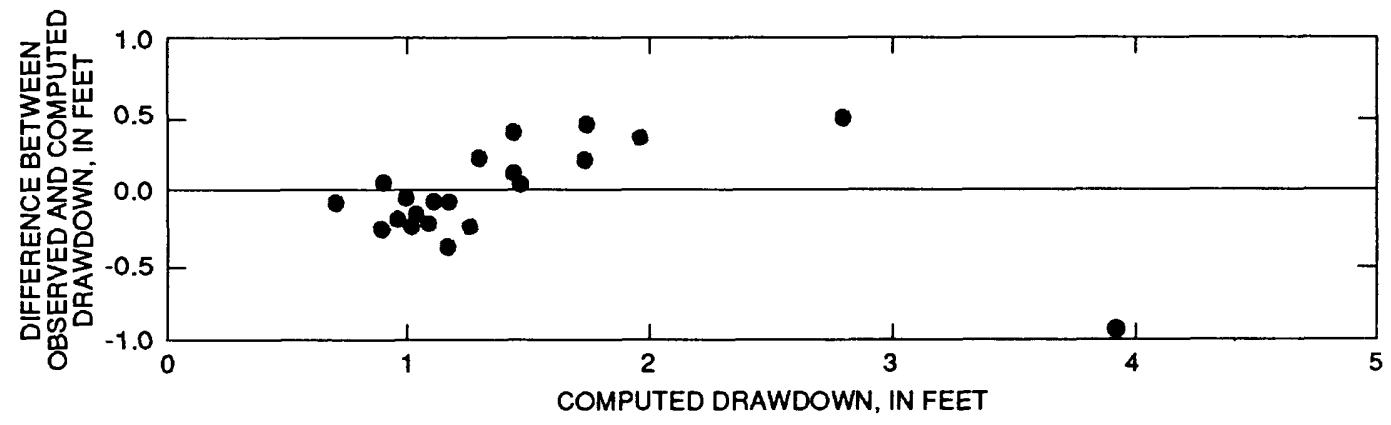

Figure 14.-- Difference between observed drawdowns and drawdowns computed by transientstate simulation, plotted in relation to computed drawdowns.

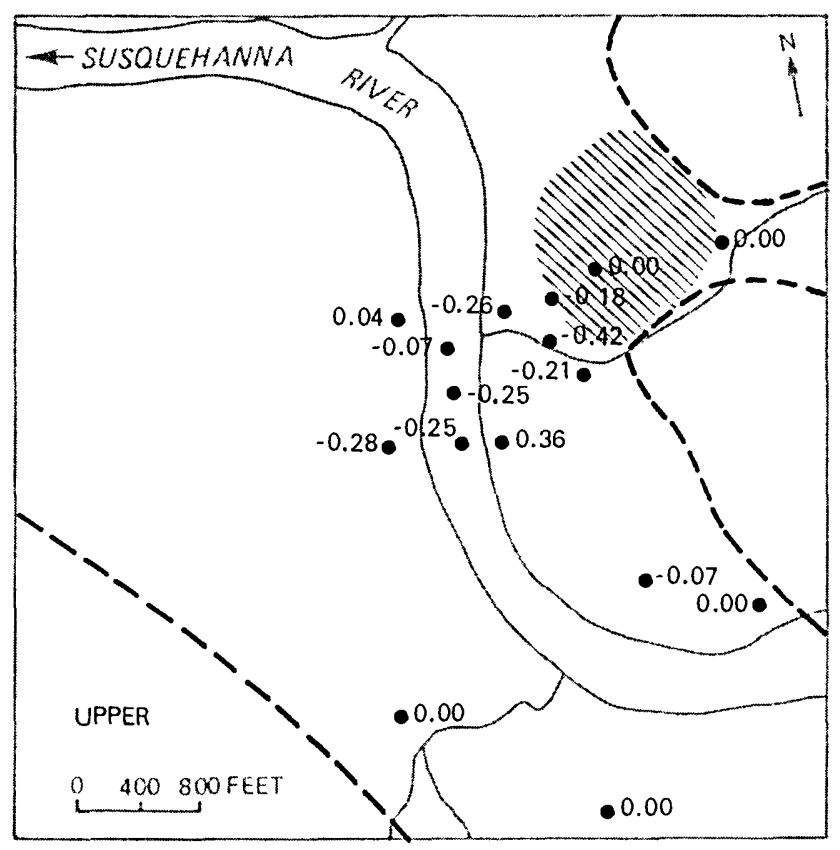

EXPLANATION

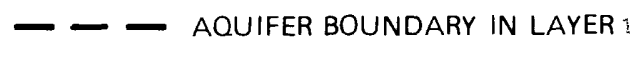

- TILL BOUNDARY

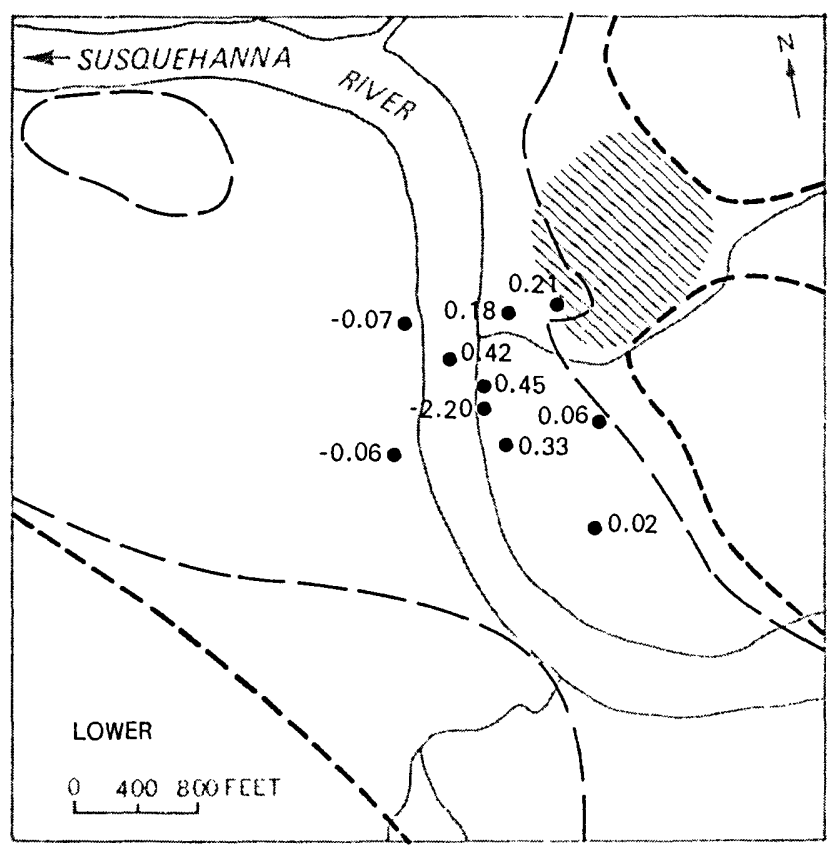

CONSTRUCTION LANDFILL

- 0.06 OBSERVATION WELL, NUMBER IS RESIDUAL IN FEET

Figure 15.-- Distribution of differences between observed drawdowns and drawdowns computed by transient-state simulation in upper and lower parts of aquifer. 
tive set of values could probably be used to obtain equally low model error and less bias. Sensitivity analysis and nonlinear regression analysis, discussed later, were used to develop an alternative set of values.

A separate transient-state simulation was run to compare drawdowns measured during a previous test at the Kirkwood well field in February 1984 with drawdowns computed by the calibrated model. Plots of drawdown as a function of time are shown in figure 16 for two observation wells $30 \mathrm{ft}$ from production well GP3 (fig. 9), which was pumped at 2,000 gal $/ \mathrm{min}$. Observation wells GS8A and GS8B have 5-ft screens that are set above and opposite the production well screen, respectively. The simulated drawdowns closely match those observed $100 \mathrm{~min}$ after the start of the test, indicating that the calibrated values of hydraulic conductivity are reasonable estimates. The simulated drawdowns do not match the early drawdowns as well, indicating that the calibrated value of the storage coefficient may not be as accurate.

\section{Simulation of Ground-Water Withdrawals}

The calibrated model was used to simulate steadystate ground-water flow to production wells in the Kirkwood and Conklin well fields to delineate the catchment area associated with each well field and to estimate the quantity of flow from various points of recharge within the Kirkwood catchment area. The steady-state simulation represented conditions in October 1984 when the aquifer system was at a shortterm equilibrium and water levels were not changing. Because the aquifer responds rapidly to changes in river stage, usually within a few days, ground-water levels fluctuate throughout the year. River discharge was relatively constant during the late summer and early fall of 1984 (fig. 8C), however, and river stage fluctuated less than $0.2 \mathrm{ft}$ during the first half of October 1984 (fig. 17). The average recharge rate of $22 \mathrm{in} / \mathrm{yr}$ reported for this area by Randall (1977) was reduced to 9 in/yr in the calibrated steady-state simulations to match the seasonally low water levels measured in October 1984.

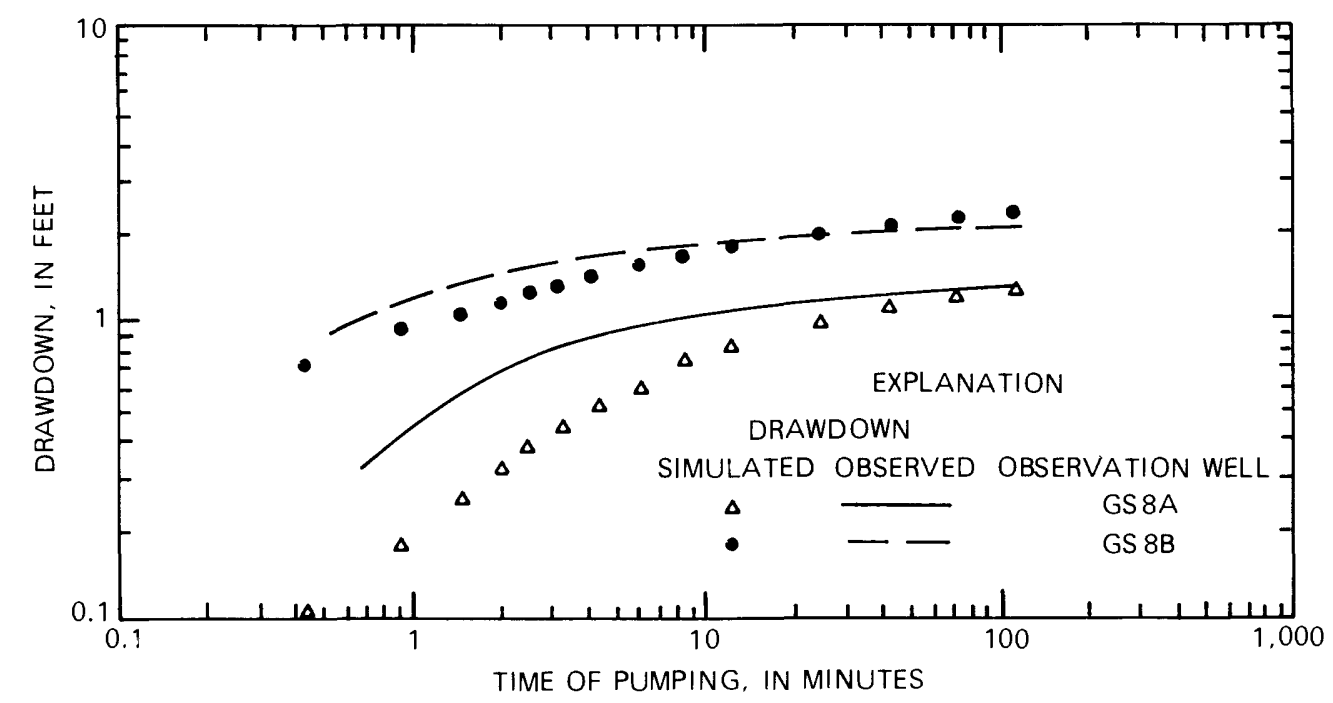

Figure 16.-- Drawdown as a function of time in observation wells GS8A and GS8B measured during February 1984 aquifer test and computed by transient-state simulation with calibrated model.

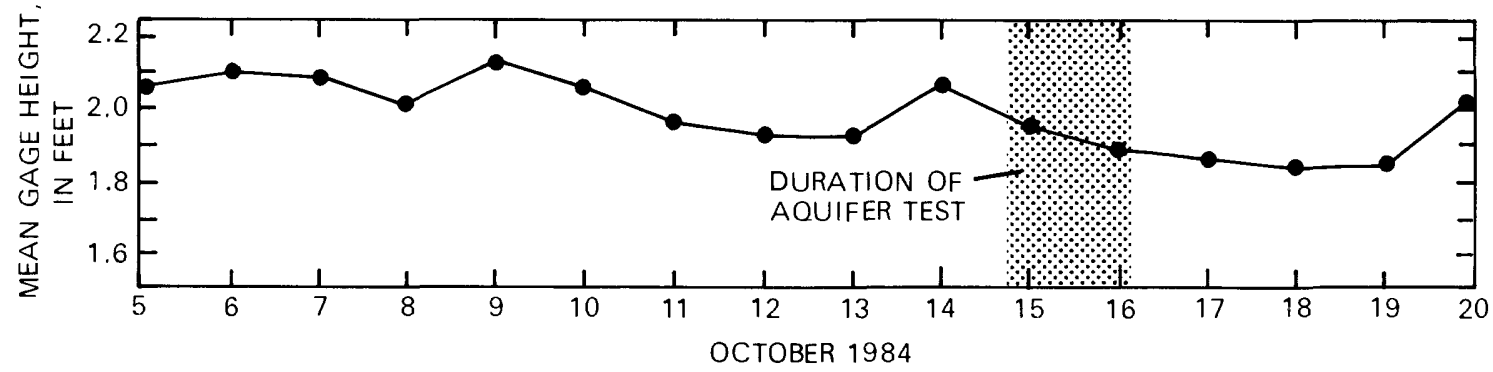

Figure 17.-- Daily gage height of the Susiquehanna River at Conklin, October 1984. 
The simulated flow direction and points of recharge to production wells are shown by the flow net in figure 18; hydraulic-head contours for layer 1 , which represents the water table, are shown separately in figure 19. The flow net is based on streamlines constructed from flow rates simulated through each model block. Flows across row and column boundaries were summed for each model layer to obtain a two-dimensional representation of the flow system (Yager, 1986, fig. 21). The spacing of the streamlines around the pumping wells in figure 18 was chosen such that the rate of ground-water flow between any two streamlines is the same. The size of the well-field catchment areas defined by the flow net for well GP1 in Kirkwood is 250 acres $\left(0.39 \mathrm{mi}^{2}\right)$; that for well C2 in Conklin is 51 acres $\left(0.08 \mathrm{mi}^{2}\right)$.

Recharge within the catchment area of the Kirkwood well field was estimated from the groundwater budget computed by a steady-state simulation of ground-water withdrawals in October 1984. Recharge includes (1) direct recharge from precipitation, (2) infiltration from tributary streams, (3) induced infiltration from the Susquehanna River, and (4) underflow through model boundaries. The relative contributions of these sources to the total well-field production are listed in table 2. The major source of recharge ( 58 percent) was infiltration from the river.

Table 2.--Recharge to Kirkwood well-field catchment from major sources during October 1984.

[Recharge values are in million gallons per day.]

\begin{tabular}{lcc}
\hline Source of recharge & Volume & $\begin{array}{c}\text { Percentage } \\
\text { of total }\end{array}$ \\
\hline $\begin{array}{c}\text { Direct recharge from } \\
\text { precipitation }\end{array}$ & 0.16 & 15 \\
$\begin{array}{c}\text { Infiltration from } \\
\text { tributary streams }\end{array}$ & .03 & 3 \\
$\begin{array}{c}\text { Infiltration from the } \\
\quad \text { Susquehanna River }\end{array}$ & .63 & 58 \\
$\begin{array}{c}\text { Underflow across } \\
\text { model boundaries } \\
\text { Total }\end{array}$ & .26 & 24 \\
Size of catchment area $=0.39$ square miles & 100 \\
\hline
\end{tabular}

\section{Sensitivity Analysis}

Sensitivity analysis of a numerical model entails a series of simulations in which the values for selected aquifer properties are varied over a specified range. These properties are constants in the equation of ground-water flow (eq. 1, p. 13) and are referred to as model parameters. The sensitivity of the model to the change in value of a given parameter is measured by the resulting change in head or drawdown. The model is said to be sensitive to a parameter if a change in the value of that parameter results in a significant change in head. Model calibration cannot be used to estimate parameters to which the model is insensitive.

Despite the usefulness of a sensitivity analysis in evaluating estimates of parameter values, it has several practical limitations. For example, the aquifer properties being evaluated are generally varied independently; thus, the effect of a simultaneous change in two parameters is not considered. Although two or more parameters could be varied simultaneously, the results are difficult to interpret. In addition, the flow region is typically divided into several zones during model calibration, and a constant value is assumed for each property throughout the entire zone. The sensitivity of the model to the shape and number of these zones cannot be determined if the zonation pattern remains constant during sensitivity analysis. A third difficulty is in interpreting model sensitivity from the given range of aquifer-property values. A model may be sensitive to changes in hydraulic-conductivity values over one or two orders of magnitude but sensitive to changes in a specified-head boundary of only a few feet. Therefore, model sensitivity to the aquifer properties of concern generally is tested over the range assumed reasonable for each parameter.

\section{Sensitivity of Transient-State Model}

Sensitivity analysis was used to identify parameters to which the transient-state model used in model calibration was most sensitive. A range of values over which the RMS difference between observed and calculated drawdowns (eq. 8) was near minimum was identified for each parameter. Drawdowns simulated for the 23-hour test were relatively insensitive to the specifiedhead boundary because the simulated drawdown cone had not reached the model boundaries, and flow to the pumped well was derived primarily from storage. Thus, lateral flows to and from the modeled area were unaffected by the simulated aquifer test.

Values for the five aquifer properties listed in table 3 (p. 25) were varied in transient-state simulations of the October 1984 aquifer test at the Kirkwood well field. A total of 26 simulations were run. The zonation pattern used in the model was fixed, and the ratio of the anisotropy of the upper part of the aquifer (layers 1 and 2) to the lower part (layers 3 and 4) was held constant. The zone of maximum hydraulic conductivity in the aquifer $(\mathrm{Kmax})$ is zone 7 in layer 3 (fig. 11C).

Residuals. The model was quite sensitive to changes in three parameters: anisotropy, vertical hydraulic conductivity of the riverbed, and maximum hydraulic conductivity of the aquifer (fig. 20). The smallest residuals were obtained over a narrow range in anisotropy $(\mathrm{Kv})$, 


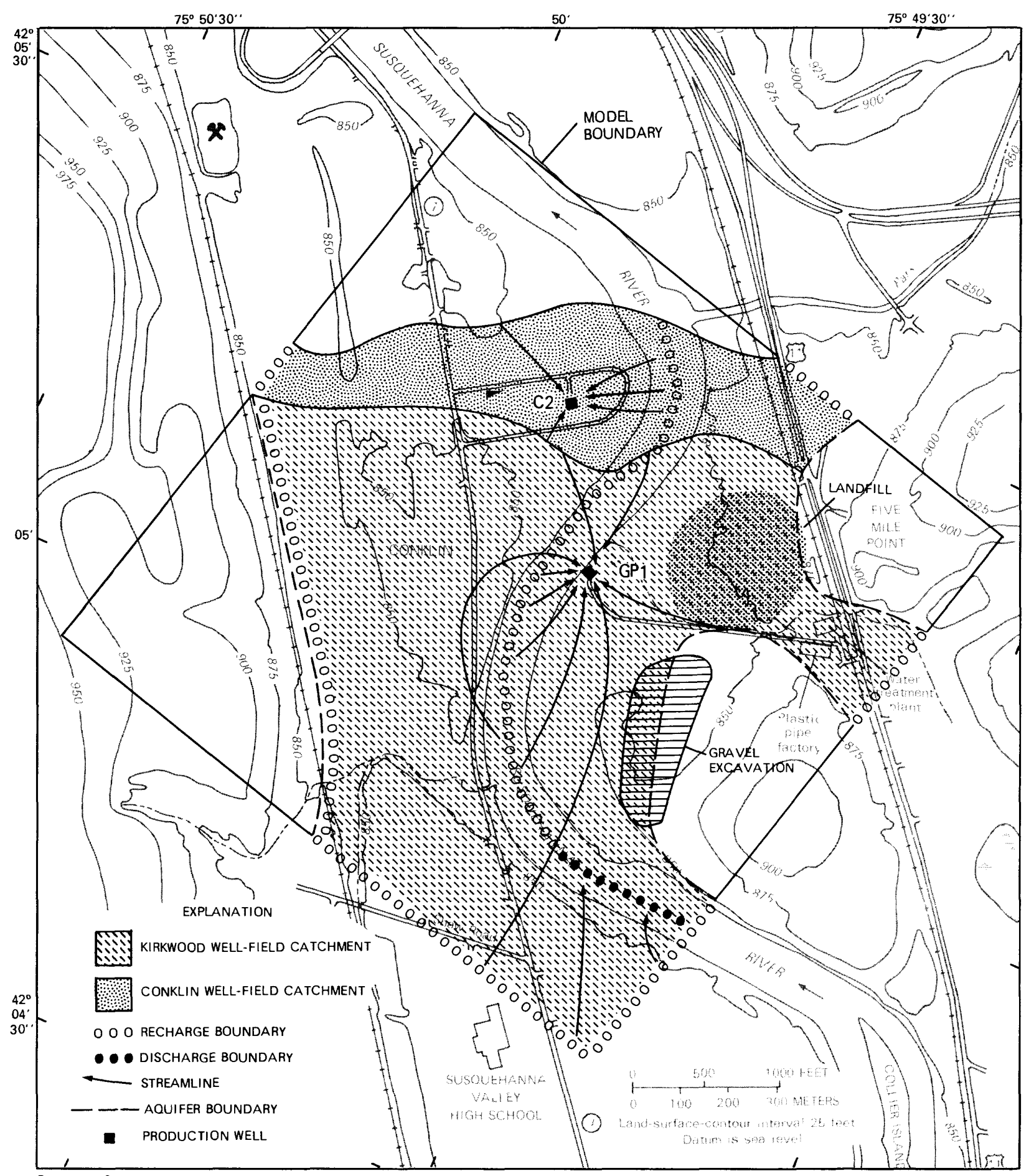

Base from Susquehanna River Basin Commission, 1974

Figure 18.-- Catchment area for production wells and direction of ground-water flow derived from steadystate simulation of ground-water withdrawals. 


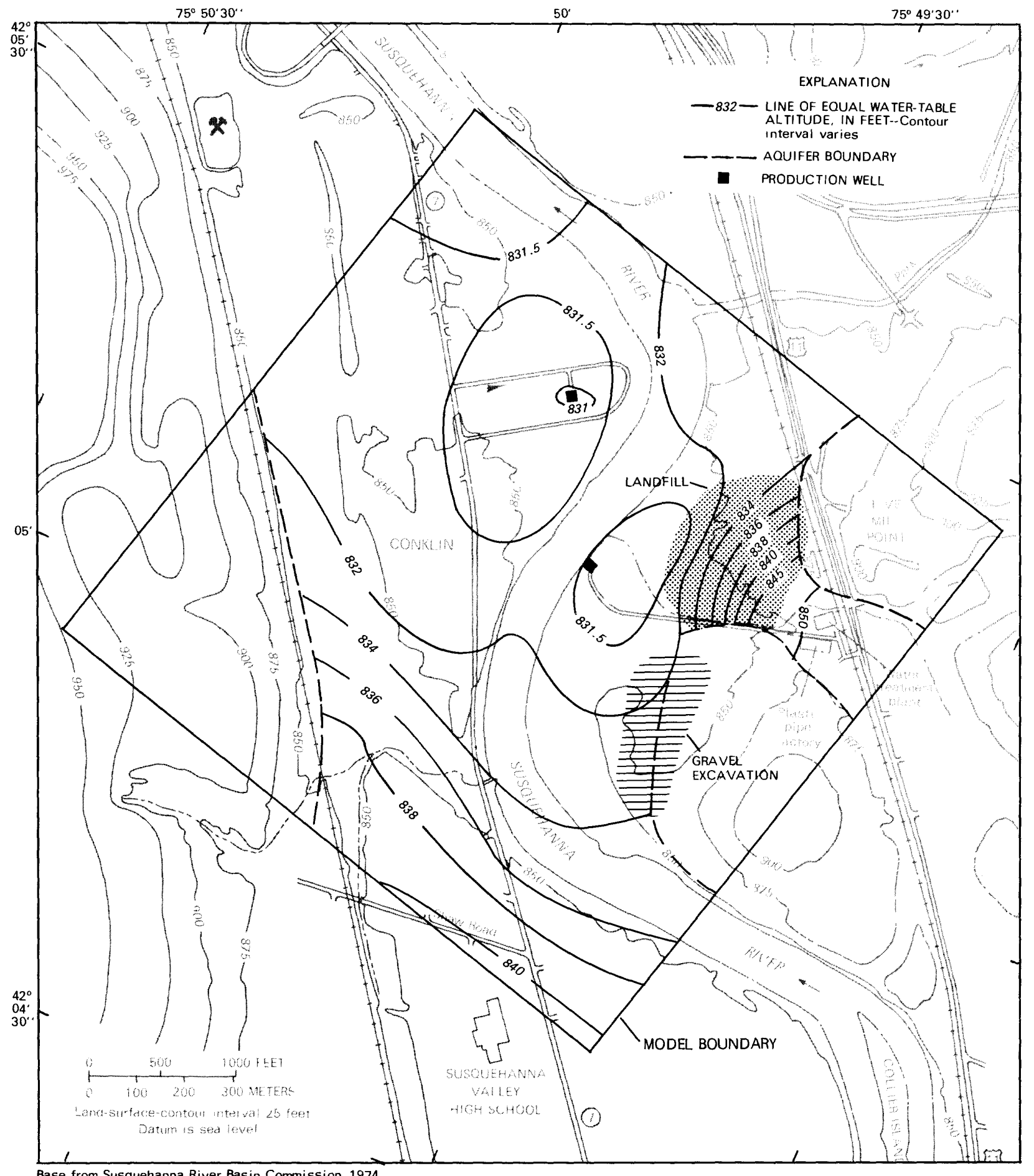

Figure 19.-- Water-table contours derived from steady-state simulation of ground-water withdrawals. 


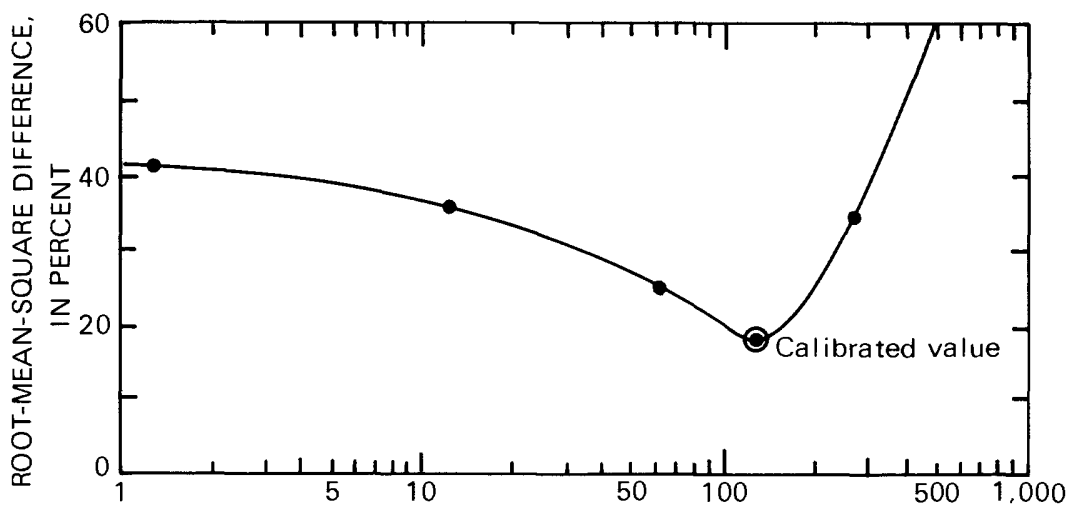

A. ANISOTROPY OF LOWER PART OF AQUIFER

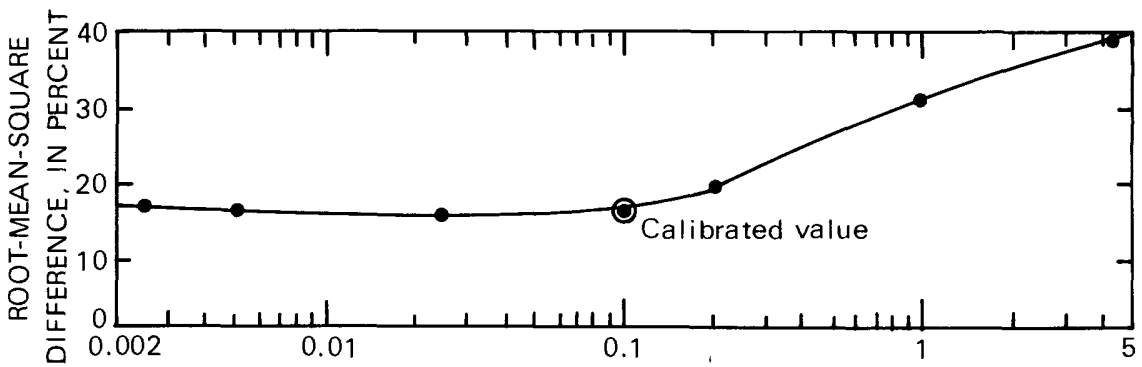

B. VERTICAL HYDRAULIC CONDUCTIVITY OF RIVERBED, IN FEET PER DAY

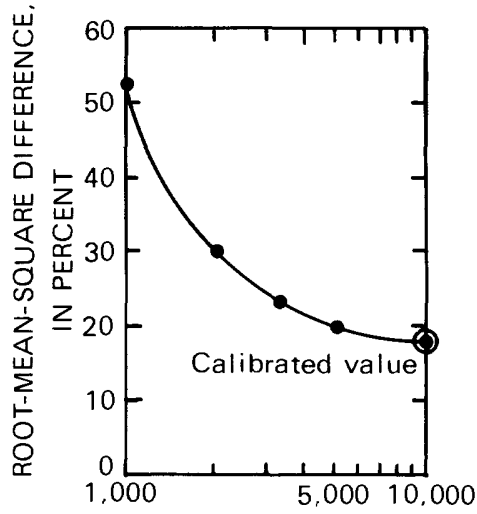

C. MAXIMUM HYDRAULIC

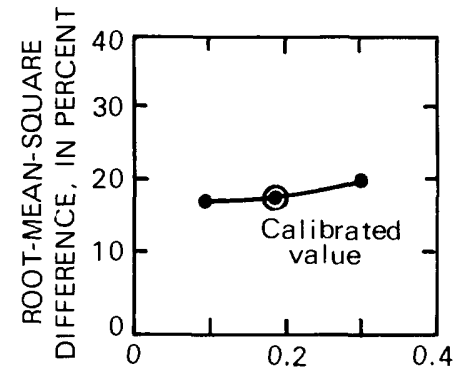

CONDUCTIVITY OF

AQUIFER, IN FEET PER DAY

D. SPECIFIC YIELD

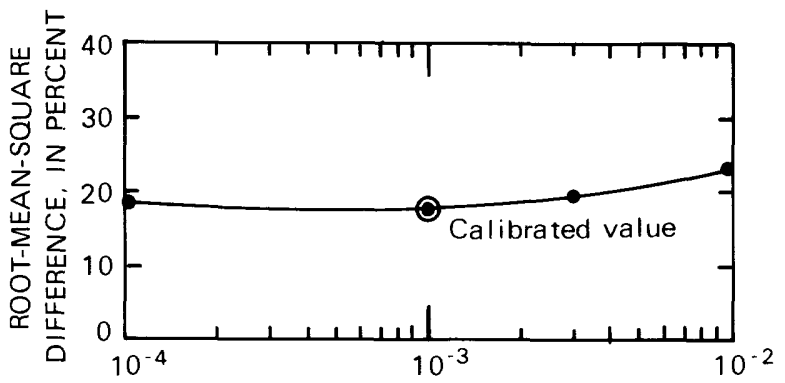

E. STORAGE COEFFICIENT

Figure 20.-- Model sensitivity to selected aquifer properties, expressed as root-mean-square difference between simulated and observed drawdown over the range of values tested:
A. Anisotropy of lower part of aquifer.
D. Specific yield.
$B$. Vertical hydraulic conductivity of riverbed.
E. Storage coefficient.
C. Maximum hydraulic conductivity of aquifer. 
Table 3.--Aquifer properties investigated in sensitivity analysis.

\begin{tabular}{ll}
\hline \multicolumn{1}{c}{ Property } & Symbol \\
\hline $\begin{array}{c}\text { Vertical hydraulic conductivity } \\
\text { of riverbed }\end{array}$ & $\mathrm{Kr}$ \\
$\begin{array}{c}\text { Maximum hydraulic conductivity } \\
\text { of aquifer material } \\
\text { Anisotropy of aquifer material } \\
\text { (ratio of horizontal to vertical } \\
\text { hydraulic conductivity) }\end{array}$ & $\mathrm{Kmax}$ \\
$\begin{array}{l}\text { Storage coefficient } \\
\text { Specific yield }\end{array}$ & $\mathrm{Kv}$ \\
\hline
\end{tabular}

increasing from 18 percent to 35 percent as anisotropy was increased by a factor of 2 . Model error was sensitive to decreasing the value of maximum hydraulic conductivity of the aquifer ( $\mathrm{Kmax}$ ) and to increasing the value of vertical hydraulic conductivity of the riverbed $(\mathrm{Kr})$. Decreasing Kmax by 80 percent from 10,000 to $2,000 \mathrm{ft} / \mathrm{d}$ increased the RMS difference from 18 percent to 30 percent, but no values were tested above $10,000 \mathrm{ft} / \mathrm{d}$. Decreasing $\mathrm{Kr}$ had little effect on the residuals, but increasing $\mathrm{Kr}$ fivefold from 0.1 to $0.5 \mathrm{ft} / \mathrm{d}$ increased the RMS difference from 18 percent to 25 percent.

Model sensitivity to changes in storage coefficient and specific yield is time-dependent. Observed drawdowns that were used to calibrate the model were measured after the early drawdowns associated with the storage coefficient had stabilized but before the late drawdown associated with specific yield had occurred. This condition is illustrated on the type curve describing drawdowns produced by pumping production well GP1 with $\sigma=0.004$, the ratio of storage coefficient to specific yield, computed with values obtained through model calibration (fig. 21).

The time of measurement at observation well VO3 ( $200 \mathrm{ft}$ from the production well) is located along the flat portion of the type curve that corresponds to a period in which the drawdown was temporarily constant. The length of the flat part of the curve is related to the value of $\sigma$ (Neuman, 1975, p. 33). Type curves for $\sigma=0.04$ and 0.0004 (fig. 21) indicate that changing the value of $\sigma$ over the range considered in the sensitivity analysis would cause only small changes in computed drawdown at the time of measurement. Therefore, the drawdown data used in model calibration provide little information on the value of storage coefficients or specific yield.

Distribution of model sensitivity. Sensitivity in terms of the RMS difference is a measure of the average effect of changes in parameter values over all observation points. If the RMS difference is to be an accurate measure of model sensitivity, the observation points should be in sensitive areas of the model. Model sensitivity may also be time dependent in the transient-state simulations that were used to calibrate the model, but this effect was not investigated.

The lateral variation of model sensitivity is illustrated in figure 22 , which shows changes in the drawdown distribution that result from changes in three

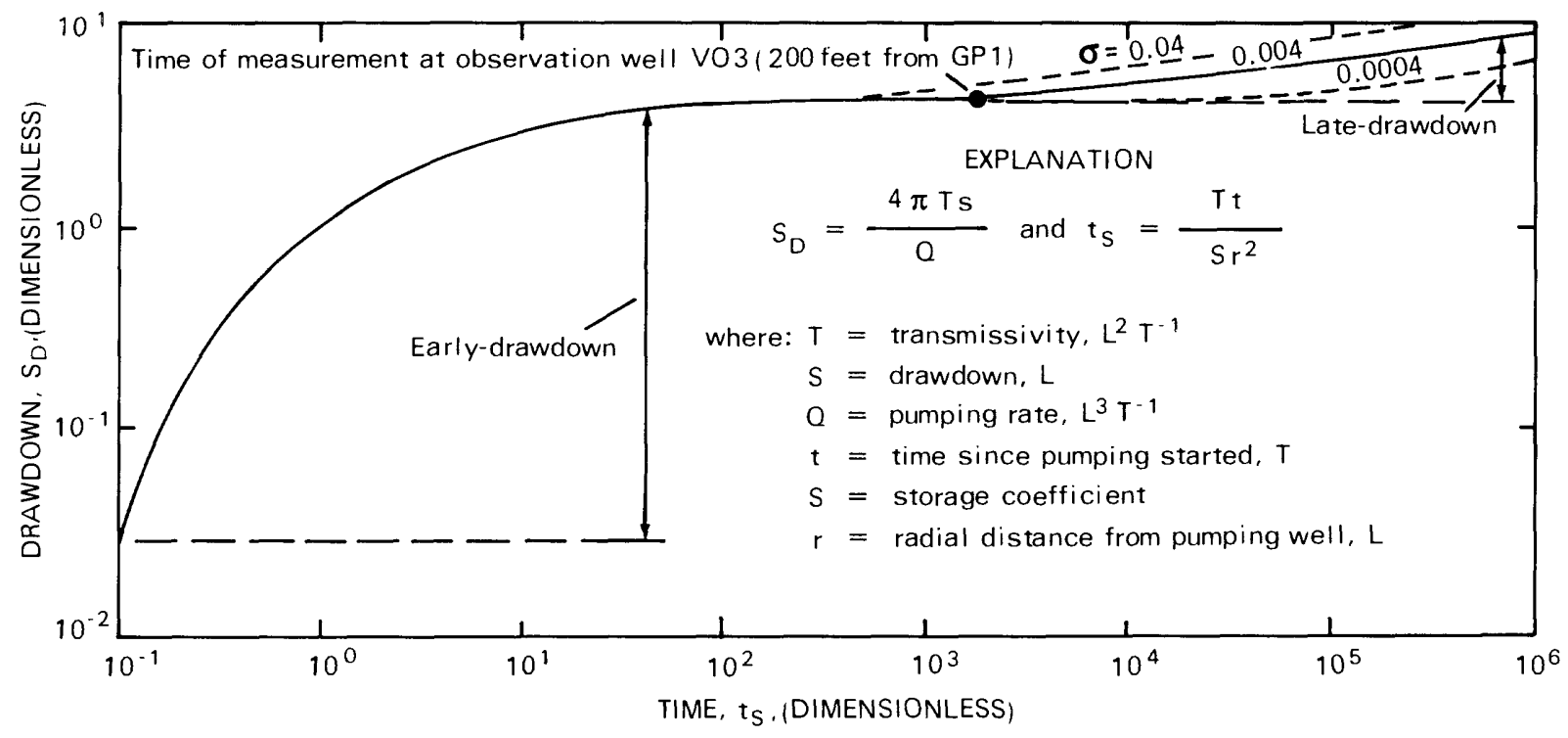

Figure 21.-- Type curves relating drawdown to time in a fully penetrating observation well (VO3), for values of $\sigma$ (ratio of storage coefficient to specific yield) included in sensitivity analysis, calculated by Neuman's method (1975) to account for partial penetration in production well GP1. 


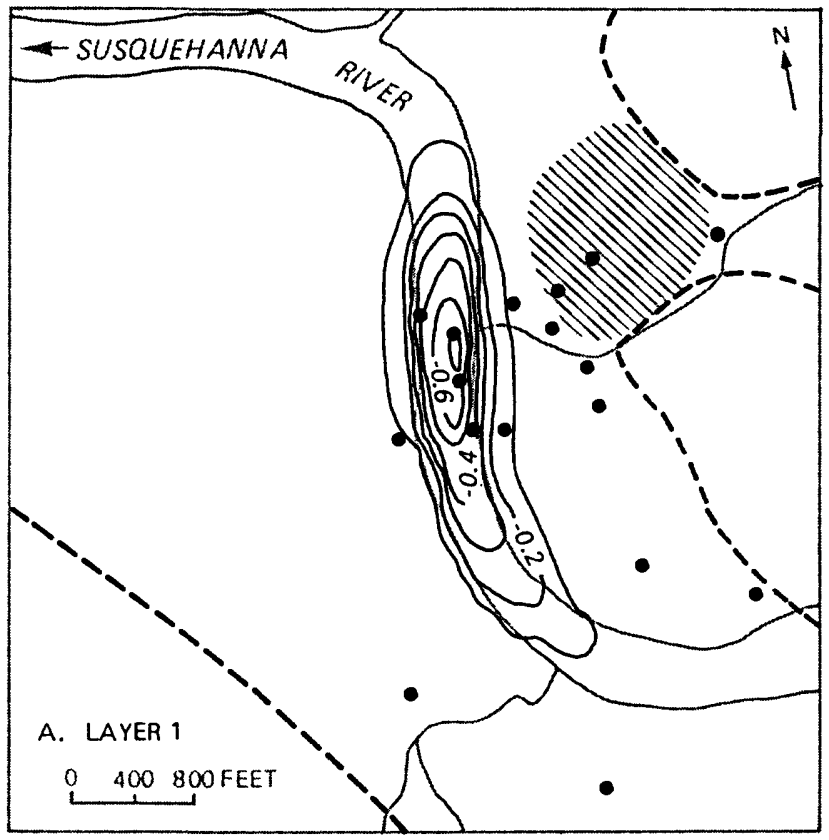

A. In model layer 1 with vertical hydraulic conductivity of riverbed $(\mathrm{Kr})$ increased tenfold, from 0.1 to $1.0 \mathrm{ft}$.

\section{EXPLANATION}

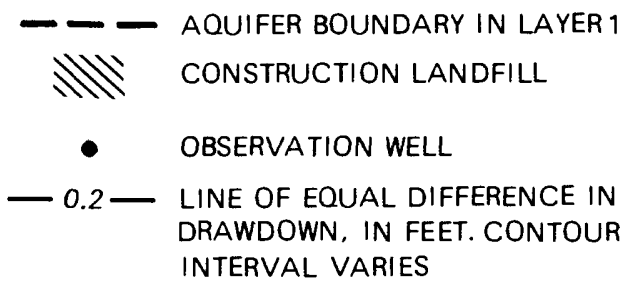

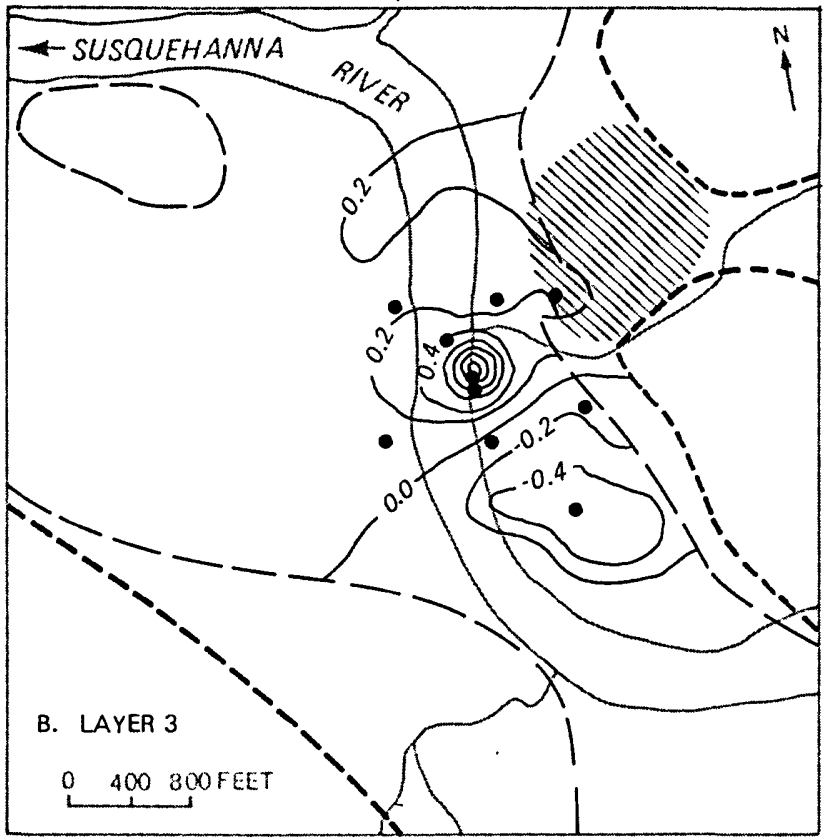

$B$. In model layer 3 with maximum hydraulic conductivity of aquifer (Kmax) decreased by 80 percent, from 10,000 to $2,000 \mathrm{ft} / \mathrm{d}$.

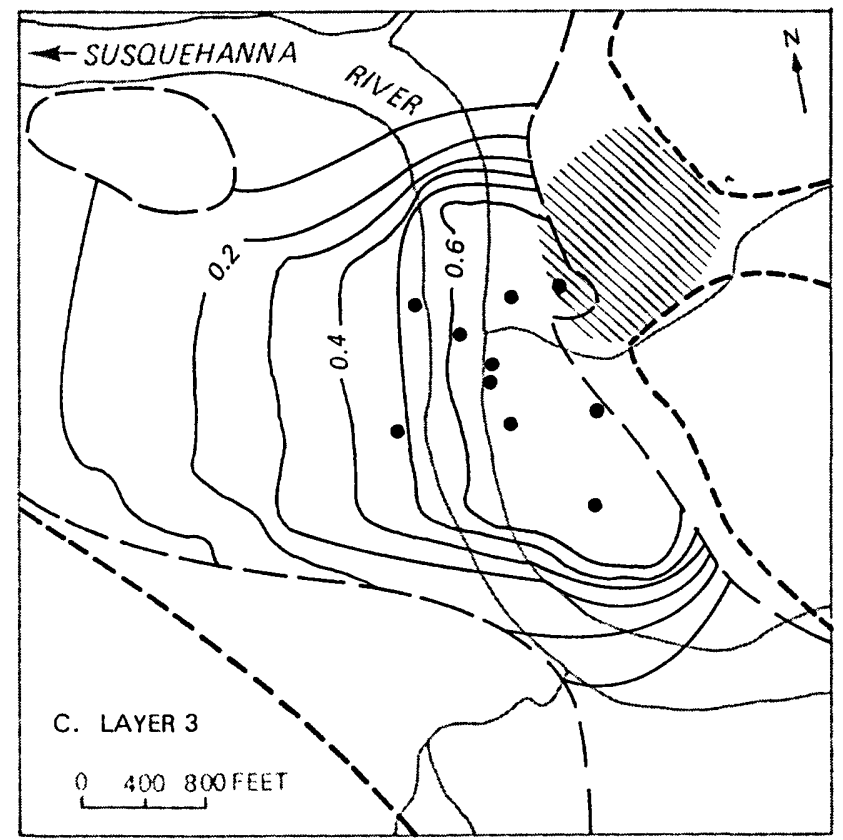

C. In model layer 3 with anisotropy $(K v)$ doubled from 125 to 250 in lower part of aquifer and from 250 to 500 in upper part.

Figure 22.-- Change in simulated drawdown resulting from changes in values of aquifer properties in sensitivity analysis. 
parameters to which the model is most sensitive- $-\mathrm{Kr}$, $\mathrm{Kmax}$, and Kv. The contours represent the difference between the drawdown distribution computed from the calibrated value and the distribution computed from an arbitrary value that increased model error.

The area of greatest model sensitivity to changes in vertical hydraulic conductivity of the riverbed $(\mathrm{Kr})$ was beneath the river in layer 1 (fig. 22A); the sensitivity of lower model layers in this area was much smaller. The three observation points in the river yield the best information for estimating $\mathrm{Kr}$ because they are within the area that is most sensitive to this parameter. The area of greatest model sensitivity to changes in maximum hydraulic conductivity of the aquifer (Kmax) was in layer 3 near the pumped wells and near the southern edge of the drawdown cone (fig. 22B). These areas contain several observation points. Model sensitivity to anisotropy (Kv) extends over a wide area in layer 3 (fig. 22C).

\section{Sensitivity of Steady-State Model}

Steady-state simulations of the short-term equilibrium period in October 1984 were used to investigate the sensitivity of simulated infiltration from the river and well-field catchment-area size to changes in the three parameters to which the model was sensitive in transient simulations--hydraulic conductivity of the riverbed, maximum hydraulic conductivity of the aquifer, and anisotropy.

River infiltration to well field. Changing anisotropy or maximum hydraulic conductivity had little effect on the percentage of river water in water pumped from the Kirkwood well field (fig. 23). Changing vertical hydraulic conductivity of the riverbed $(\mathrm{Kr})$ affected the predicted volume of recharge through river infiltration significantly, however. Decreasing $\mathrm{Kr}$ tenfold to 0.01 $\mathrm{ft} / \mathrm{d}$ reduced river infiltration to less than 10 percent of the water pumped by the Kirkwood well field, and increasing it tenfold to $1.0 \mathrm{ft} / \mathrm{d}$ increased the contribution of river infiltration to almost 70 percent of the amount pumped. Increasing $\mathrm{Kr}$ above $1.0 \mathrm{ft} / \mathrm{d}$ had little effect because the vertical hydraulic conductivity of the aquifer material $(2.0 \mathrm{ft} / \mathrm{d})$ became the limiting factor.

Sensitivity analysis suggests that steady-state simulation is sensitive to $\mathrm{Kr}$ values over two orders of magnitude $(0.01$ to $1.0 \mathrm{ft} / \mathrm{d})$, whereas transient-state simulation is insensitive to values of $\mathrm{Kr}$ below $0.1 \mathrm{ft} / \mathrm{d}$. This apparent contradiction is due to the effect of the

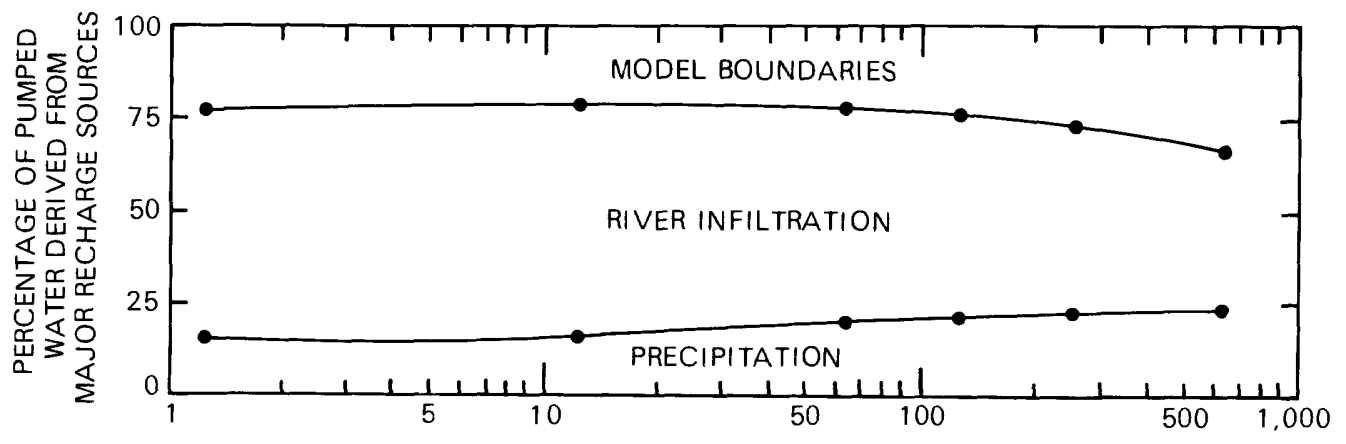

A. ANISOTROPY OF LOWER PART OF AQUIFER

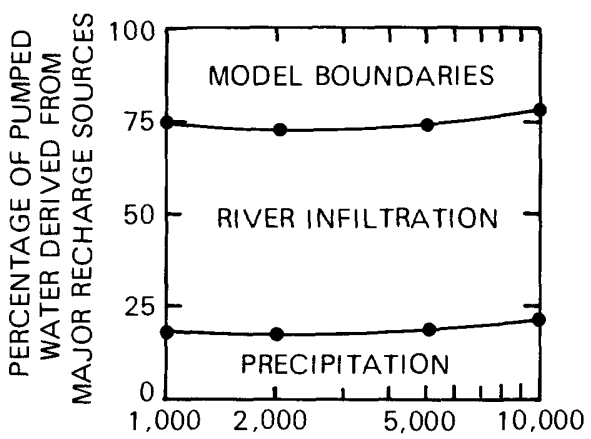

B. MAXIMUM HYDRAULIC CONDUCTIVITY OF AQUIFER, IN FEET PER DAY

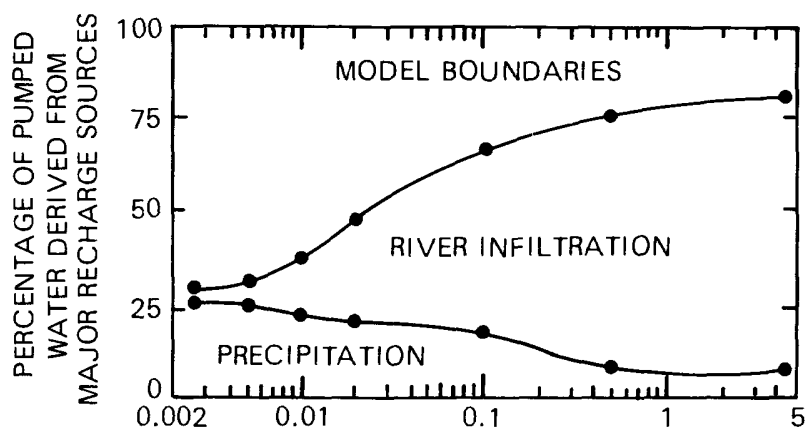

C. VERTICAL HYDRAULIC CONDUCTIVITY OF RIVERBED, IN FEET PER DAY

Figure 23.-- Percentage of river water in water pumped from the Kirkwood well field as a function of aquifer properties: A. Anisotropy of lower part of aquifer. B. Maximum hydraulic conductivity of aquifer.C.Vertical hydraulic conductivity of riverbed. 
storage terms in transient-state simulation, which represented additional sources of ground water that compensate for the decreased river infiltration with decreasing values of $\mathrm{Kr}$. As a result, lowering the $\mathrm{Kr}$ value tenfold from $0.1 \mathrm{ft} / \mathrm{d}$ to $0.01 \mathrm{ft} / \mathrm{d}$ increased drawdowns in transient simulations by about $0.7 \mathrm{ft}$ in the sensitive model area in layer 1 (fig. 22A). The same change in $\mathrm{Kr}$ increased the head difference between steady-state simulation of pumping and nonpumping conditions by 2.3 $\mathrm{ft}$, however, which suggests that the value of $\mathrm{Kr}$ is best estimated by steady-state simulation or by transientstate simulation representing a longer time period than the 1-day interval used.

Size of well-field catchment area. The sensitivity of the Kirkwood well field's catchment-area size to the value of $\mathrm{Kr}$ is shown in figure 24 . Increasing $\mathrm{Kr}$ tenfold to $1.0 \mathrm{ft} / \mathrm{d}$ decreased the size of the catchment area so that it did not extend across the river, and decreasing $\mathrm{Kr}$ tenfold to $0.01 \mathrm{ft} / \mathrm{d}$ increased the size of the catchment area to include nearly the entire modeled area. Uncertainty in the value of $\mathrm{Kr}$ is the most limiting factor in model delineation of the catchment area because the catchment area is relatively insensitive to the other parameters.

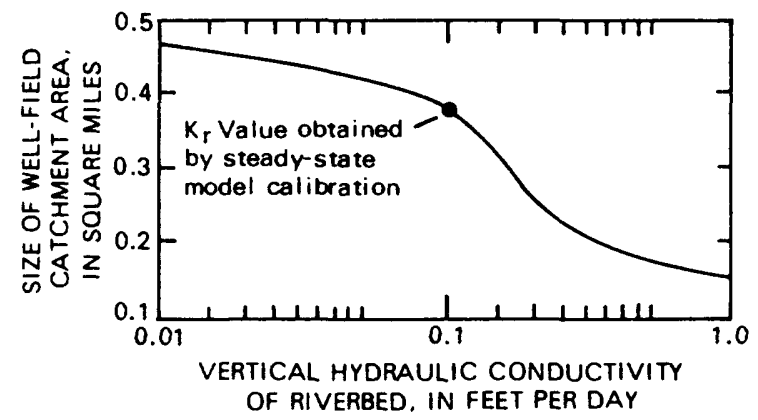

Figure 24.--Size of well-field catchment area as a function of vertical hydraulic cenductivity of riverbed.

\section{Nonlinear Regression}

Ground-water flow simulations solve the following flow equation:

$$
\underline{\mathrm{Dh}}=\underline{\mathrm{q}}
$$

where: $\underline{h}$ is a vector of hydraulic head;

$\underline{D}$ is a coefficient matrix involving aquifer properties, such as hydraulic conductivity or transmissivity; and

$\mathrm{g}$ is a vector of ground-water sources and(or) sinks.

If ground-water sources and(or) sinks and hydraulic heads everywhere in the aquifer could be measured directly, then a single coefficient matrix $\underline{D}$ representing aquifer properties could be calculated explicitly from the flow equation. Unfortunately, this is not the case, and numerical simulation is used to estimate aquifer properties in $\underline{D}$ from limited information on hydrogeology and measured water levels. The common approach is to adjust the values of aquifer properties until the difference between measured water levels and those calculated from the flow equation is minimized. This trialand-error process is known as model calibration.

Although values of aquifer properties change as a continuous function throughout the aquifer system, they are represented in numerical models of ground-water flow as a discrete function, that is, by zones with constant values. Estimating values of aquifer properties with ground-water flow models involves identifying the zonation pattern (the shape and number of zones) for each property and the value of the property in each zone.

Simulation of heads by ground-water flow models has two inherent sources of error--(1) model error resulting from simplification of aquifer dimensions and heterogeneity, and (2) estimation error resulting from uncertainty as to the value of the aquifer properties. Increasing the number of parameters in a model will generally decrease model error but will increase the estimation error (Neuman, 1973; Yeh, 1986). Thus, the modeler's task is to select a sufficient number of parameters to approximate the aquifer system correctly but to keep this number small enough that the assigned values are reasonably correct.'

Several investigators have suggested alternative methods for estimating aquifer properties with the flow equation (eq. 9). Instead of solving this equation for hydraulic head $\underline{\mathrm{h}}$, these methods solve for values of the hydrogeologic parameters in the coefficient matrix $\underline{D}$ on the assumption that the head distribution is partly known. Solving the ground-water flow equation in this way is known as the ground-water inverse problem. Yeh (1986) summarizes several methods that have been developed to solve the ground-water inverse problem.

This study used a method developed by Cooley (1977) that uses nonlinear regression. An advantage of this method is that it allows the use of statistical techniques to test model fit and the validity of assumptions as well as the reliability of the estimated values. Nonlinear regression is used in place of linear regression because the flow equation is generally nonlinear with respect to the hydrogeologic parameters. To simplify mathematical calculations, the nonlinear equations are linearized under certain assumptions; Cooley and Naff (1985, p. 141-170) discuss these in detail.

Cooley and Naff (1985) use the Gauss-Newton method to obtain the regression solution to the flow equation through the sensitivity matrix $\underline{X}$, which is derived by differentiating the flow equation with respect to the hydrogeologic parameters. In mathematical terms $\underline{X}$ is an $n \times p$ matrix defined as: 


$$
\begin{gathered}
X_{i j}=\frac{\partial h_{i}}{\partial b_{j}}=D^{-1} \frac{\partial q}{\partial b_{j}}-\frac{\partial \underline{D}}{\partial b_{j}} h_{i} \\
i=1, n ; j=1, p
\end{gathered}
$$

where: $\quad b_{j}$ is one of the phydrogeologic parameters included in set $\underline{b}$; and

$\mathrm{n}$ is the number of observations of hydraulic head.

Cooley and Naff's method was modified for application to the three-dimensional model investigated in this study through estimation of the sensitivity matrix with a perturbation technique. Model sensitivities corresponding to a parameter $b_{j}$ were approximated by:

$$
\frac{\partial h_{i}}{\partial b_{j}} \approx \frac{h_{i}^{\prime}\left(\underline{b}+\Delta b_{j} I_{j}\right)-h_{i}(\underline{b})}{\Delta b_{j}} \quad i=1, n
$$

$$
\text { where: } \begin{aligned}
\Delta b_{j} & \text { is a small increment of } b_{j}, \\
I_{j} & \text { is the jth unit vector, } \\
h_{i} & \text { is the hydraulic head computed with } \\
h_{i}^{\prime} & \text { is the hydraulic head computed with } \\
& \text { the perturbed parameter } b_{j} \text { in } \underline{b} .
\end{aligned}
$$

Values of $\underline{h}(\underline{b})$ and $\underline{h}\left(\underline{b}+\Delta b_{j} I_{j}\right)$ were obtained from the three-dimensional model. Simulations were run in which each parameter was perturbed individually, so that $p+1$ simulations were needed to compute the sensitivity matrix for one iteration of the Gauss-Newton method (Cooley and Naff, 1985, p. 145). The value of $\Delta b_{j}$ ranged from 1 to 5 percent and was chosen such that at least half the sensitivities for each parameter were not zero. These model sensitivities are analogous to those obtained in the previously discussed sensitivity analysis but are better approximated through use of a small perturbation.

The initial set of values $\underline{b}_{0}$ used in the regression analysis was the best set obtained with the calibrated model. The algorithm used in solution of the nonlinear regression written in terms of parameter set $\underline{b}_{\mathrm{r}}$ at iteration $r$ was:

1. Calculate heads $\underline{h}$ at the $\mathrm{n}$ observation points with the ground-water flow model.

2. Estimate model sensitivities, $\partial \underline{h} / \partial b_{j}$ for each parameter $b_{j}(j=1, p)$ by:

i) perturbing $b_{j}$ by $\Delta b_{j}$,

ii) calculating $\underline{h}^{\prime}$ with the ground-water flow model with $\mathrm{b}_{\mathrm{j}}+\Delta \overline{\mathrm{b}}_{\mathrm{j}}$ in $\underline{\mathrm{b}}_{\mathrm{r}}$, and

iii) calculating $\frac{\partial \underline{\mathrm{h}}}{\partial \overline{\mathrm{b}}_{\mathrm{j}}}=\frac{\underline{\mathrm{h}^{\prime}}-\underline{\mathrm{h}} \text {. }}{\Delta \mathrm{b}_{\mathrm{j}}}$
3) Compute $\underline{b}_{r+1}$ from the regression solution through MULREG, a FORTRAN 77 program given in the appendix.

4) If $\left|\underline{b}_{r}-\underline{b}_{r+1}\right|>0.01$, return to step 1; otherwise the process has converged.

\section{Application}

The zonation pattern obtained through trial-anderror calibration (fig. 11) was assumed to correctly represent the distribution of hydraulic properties of the aquifer materials. The number of parameters in the nonlinear regression was minimized by selecting six model parameters to which the model was most responsive in the sensitivity analysis. These parameters, the values obtained through calibration and regression, and their degree of error are summarized in table 4 (p. 31). The vertical hydraulic conductivity of the riverbed was estimated by the parameter $\mathrm{Kr}$. Anisotropy (the ratio of horizontal to vertical hydraulic conductivity) was estimated for the upper part of the aquifer (layers 1 and 2) and the lower part (layers 3 and 4 ) as $\mathrm{Kv} 1$ and $\mathrm{Kv} 2$, respectively. Hydraulic conductivity of the aquifer was represented by three parameters. Maximum and minimum values in layer 3 (Kmax and $\mathrm{Kmin}$ ) were both initially included in the regression, but Kmin was later held at a constant value to facilitate convergence of the method. The remaining hydraulic-conductivity zones were represented by a single parameter (Kbase) by changing their values during the regression in proportion to changes in Kbase. Hydraulic conductivity values of $50 \mathrm{ft} / \mathrm{d}$ or less were held constant during the nonlinear regression.

Three parameters (Kv1, Kmax and Kbase) met the convergence criterion of 1 percent, but the two for which the coefficients of variation were large $(\mathrm{Kr}, \mathrm{Kv} 2)$ did not. The procedure was terminated after 19 iterations because the values remained relatively stable from one iteration to the next (fig. 25), and the model was insensitive to the parameters that had not converged.

Drawdowns. The drawdown distribution computed by transient-state simulation from the optimum values obtained by nonlinear regression (fig. 26) was similar to that computed from the values obtained by trial-anderror calibration (fig. 12). Drawdowns computed from the regression values extended farther across the aquifer because the hydraulic conductivity of the aquifer was greater, and that of the riverbed was lower. The drawdowns simulated by the two sets of values differed by less than $0.2 \mathrm{ft}$ except at observation well GP2B, where drawdown increased from $4.5 \mathrm{ft}$ to $7.0 \mathrm{ft}$. The residuals shown in table 5 (p. 31) indicate that the regression technique gave a better fit to the observed data, largely 


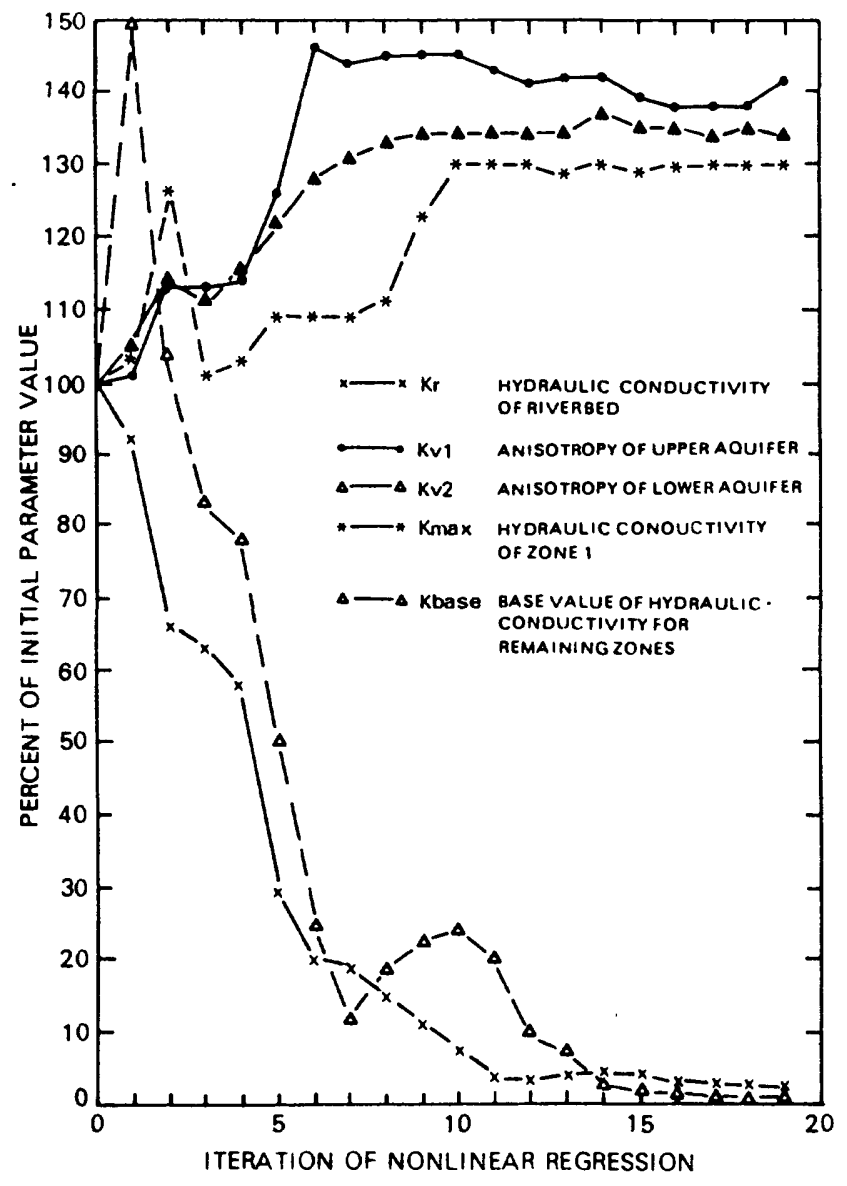

Figure 25.-- Changes in values of aquifer properties during nonlinear regression.

becaise of the improvement in the computed drawdown for GP2B. The sum of squared errors and the error variance of the residuals were each reduced by an order of magnitude from 6.1 to $0.6 \mathrm{ft}^{2}$ and 0.43 to $0.04 \mathrm{ft}^{2}$, respectively. The standard error of the residuals divided by the range in measured drawdowns is 13 percent.

Estimated values. Values of aquifer properties obtained through nonlinear regression and their standard errors are given in table 4 . Standard errors are measures of uncertainty and are equal to the square root of the variance in an estimate, given as the main diagonal of the covariance matrix shown in table 6 (p. 31). Coefficients of variation for $\mathrm{Kr}$ and $\mathrm{Kv} 2$ exceed 2,000 percent, indicating a large degree of uncertainty in these parameters. In contrast, the values for the remaining three parameters (Kv1, Kmax and Kbase) were relatively well estimated, with coefficients of variations less than 50 percent.

The coefficients of variation (table 4) obtained from the nonlinear regression indicate that the model is sufficiently sensitive to estimate hydraulic conductivity of the aquifer (Kmax and Kbase) and anisotropy of the upper part of the aquifer (Kv1). The model is insensitive to anisotropy of the lower part (Kv2), however, because observed data do not define the vertical gradient between the upper and lower parts. The conductance between the two is limited by the smaller value of $\mathrm{Kv} 1$ and thus provides no information on the value of $\mathrm{Kv} 2$.

The model is also insensitive to the vertical hydraulic conductivity of the riverbed $(\mathrm{Kr})$ because the value is small enough that the river boundary has little effect on drawdowns during the 23-hour aquifer test. This implies that recharge through induced infiltration during the simulated aquifer test was negligible compared to releases from storage within the aquifer.

The correlation between pairs of model parameters is computed from the covariance of each pair (Cooley and Naff, 1985, p. 58). The covariance and correlation matrices computed by MULREG (see appendix) are given in table 6 for the regression estimates shown in table 4. Little correlation is evident among the various aquifer properties. Anisotropy of the upper part of the aquifer (Kv1) is slightly correlated $(r=0.75)$ with hydraulic conductivity of the aquifer (Kbase) because higher values of hydraulic conductivity of the aquifer are compensated in the regression by increasing the anisotropy, which decreases the conductance between model layers. Anisotropy of the upper and lower aquifer layers, $\mathrm{Kv} 1$ and $\mathrm{Kv} 2$, are negatively correlated $(\mathrm{r}=$ 0.65 ) because if one increases, the other must decrease to maintain a given flow.

Model sensitivity. Sensitivity of the model to changes in the respective parameter values can be compared directly from contour plots of scaled sensitivities $\mathrm{Z}_{\mathrm{ij}}$, defined as:

$$
\mathrm{Z}_{\mathrm{ij}}=\mathrm{b}_{\mathrm{j}} \mathrm{X}_{\mathrm{ij}} \quad \mathrm{i}=1, \mathrm{~m} ; \mathrm{j}-1, \mathrm{p}
$$

where:

$$
\underline{Z} \text { and } \underline{X} \text { are } \begin{aligned}
& \text { computed for each of the } m \\
& \text { active blocks in the model. }
\end{aligned}
$$

These plots are similar to those shown in figure 22 except that the contours are more accurate because a smaller perturbation in parameter values was used to compute them. The plots shown in figure 27 indicate that the aquifer is most sensitive to the hydraulic conductivity of the aquifer (Kbase, fig. 27A, 27B) and anisotropy of the upper part of the aquifer (Kv1, fig. 27C, 27D). Sensitivities associated with Kbase are highest near the production wells; those associated with Kv1 are highest on the other side of the river. The latter pattern is probably related to a zone of low hydraulic conductivity in layer 1 (fig. 11A) that extends into the area of high sensitivity, indicating that the zonation pattern affects the model sensitivity. Sensitivity to Kmax is highest near the production wells and at the periphery of the drawdown cone in the zone for Kmax (figs. 27E, 27F). 
Table 4.--Values of aquifer properties obtained through nonlinear regression.

[Dashes indicate value not estimated.]

\begin{tabular}{|c|c|c|c|c|c|}
\hline $\begin{array}{l}\text { Aquifer } \\
\text { property }\end{array}$ & Symbol & $\begin{array}{c}\text { Cali- } \\
\text { bration } \\
\text { estimate }\end{array}$ & $\begin{array}{c}\text { Regression } \\
\text { estimate }\end{array}$ & $\begin{array}{l}\text { Standard } \\
\text { error }\end{array}$ & $\begin{array}{c}\text { Coefficien } \\
\text { of } \\
\text { variation } 1 \\
\text { (percent) }\end{array}$ \\
\hline $\begin{array}{l}\text { Vertical hydraulic } \\
\text { conductivity of } \\
\text { riverbed }(\mathrm{ft} / \mathrm{d})\end{array}$ & $\mathrm{Kr}$ & 0.10 & 0.002 & 0.042 & 2,100 \\
\hline $\begin{array}{l}\text { Anisotropy: } \\
\text { Upper aquifer } \\
\text { Lower aquifer }\end{array}$ & $\begin{array}{l}\text { Kv1 } \\
\text { Kv2 }\end{array}$ & $\begin{array}{l}250 \\
125\end{array}$ & $\begin{array}{r}350 \\
2\end{array}$ & $\begin{array}{l}66 \\
45\end{array}$ & $\begin{array}{r}19 \\
2,300\end{array}$ \\
\hline $\begin{array}{l}\text { Horizontal hydraulic } \\
\text { conductivity of } \\
\text { aquifer (ft/d): }\end{array}$ & & & & & \\
\hline $\begin{array}{l}\text { Value for zone } 7 \\
\text { in layer } 3\end{array}$ & $\mathrm{~K} \max$ & 10,000 & 13,000 & 5,800 & 45 \\
\hline $\begin{array}{l}\text { Value for zone } 3 \\
\text { in layer } 3\end{array}$ & $\mathrm{Kmin}$ & 500 & 210 & -- & -- \\
\hline $\begin{array}{l}\text { Base value for all } \\
\text { other zones }\end{array}$ & Kbase & 500 & 670 & 96 & 14 \\
\hline
\end{tabular}

Table 5.--Statistics of residuals obtained by calibration and nonlinear regression.

\begin{tabular}{lcc}
\hline \multicolumn{1}{c}{ Measure } & $\begin{array}{c}\text { Calibration } \\
\text { estimates }\end{array}$ & $\begin{array}{c}\text { Regression } \\
\text { estimates. }\end{array}$ \\
\hline Root-mean-square-error & 0.17 & 0.12 \\
Sum of squared error & 6.08 & .62 \\
Error variance & .43 & .04 \\
\hline
\end{tabular}

Table 6.--Correlation and covariance matrices for optimum values obtained through regression analysis.

[Shaded area is correlation matrix; unshaded area is variance-covariance matrix.]

\begin{tabular}{|c|c|c|c|c|c|}
\hline Variable & $\mathrm{Kr}$ & $\mathrm{Kv} 1$ & $\mathrm{Kv} 2$ & $K_{\max }$ & Kbase] \\
\hline $\mathrm{Kr}$ & 0.0018 & 0.0869 & -0.4764 & .0 .3056 & -0.4038 \\
\hline $\mathrm{Kvl}$ & .2436 & $4.421 \times 10^{3}$ & .6480 & -1659 & .7416 \\
\hline $\mathrm{K} v 2$ & -.9016 & $-1.93 \times 10^{3}$ & $2.016 \times 10^{3}$ & 3191 & -2305 \\
\hline$K \max$ & -75.35 & $-6.450 \times 10^{4}$ & $8.380 \times 10^{4}$ & $3.421 \times 10^{7}$ & -.2036 \\
\hline Kbase & -1.641 & $4.753 \times 10^{3}$ & $-9.973 \times 10^{2}$ & $-1.148 \times 10^{5}$ & $9.290 \times 10^{3}$ \\
\hline
\end{tabular}



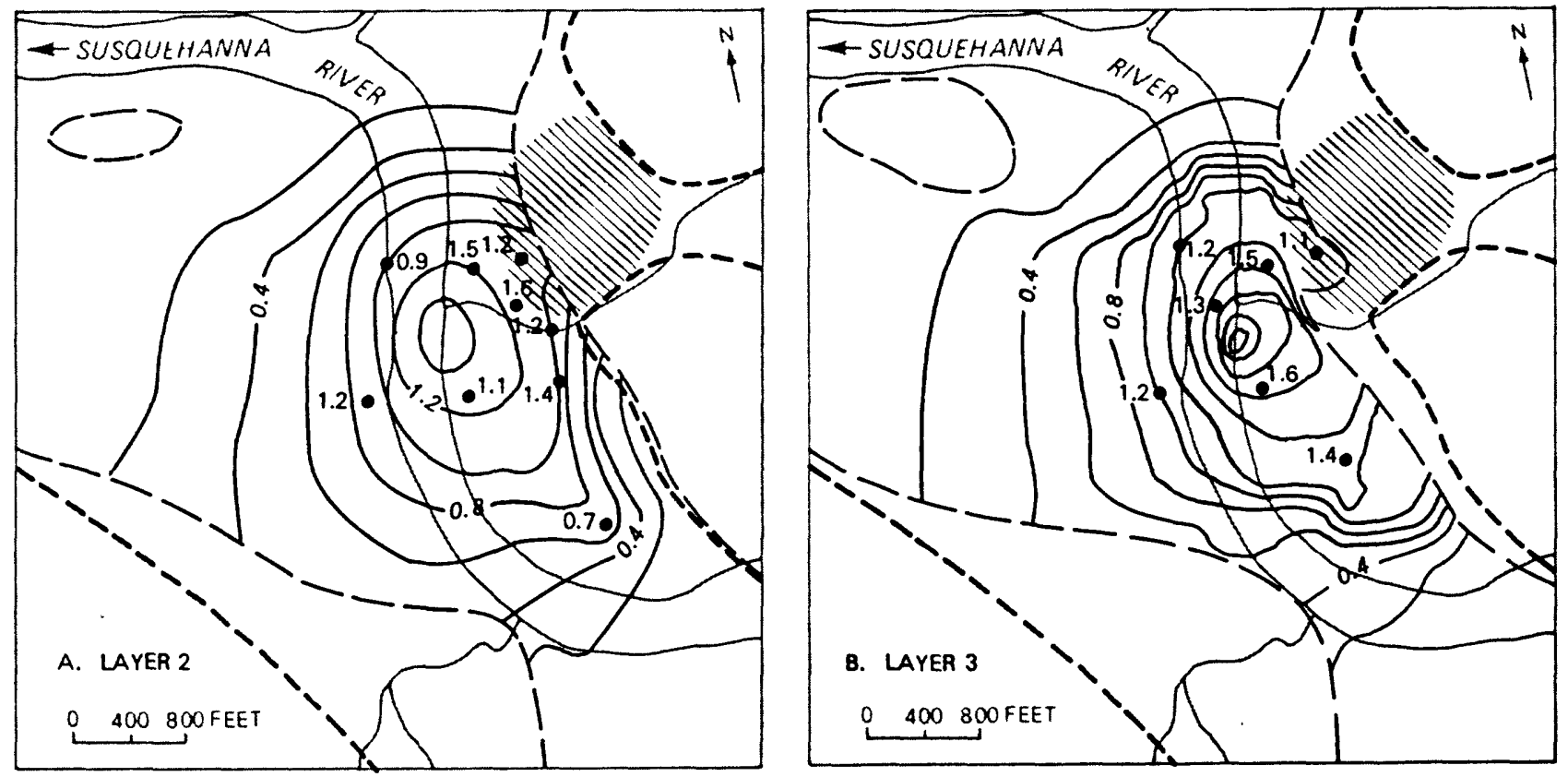

Figure 26.-- Distribution of drawdowns in model layers 2 and 3 computed by transient-state simulation of October 1984 aquifer test based on nonlinear regression values.

EXPLANATION

- - aQuIFER BOUNDARY IN LAYER1

- TILL BOUNDARY

CONSTRUCTION LANDFILL
- 0.4 - LINE OF EQUAL DRAWDOWN SIMULATED BY FLOW MODEL, CONTOUR INTERVAL 0.2 FEET

- 1.2 OBSERVATION WELL, NUMBER IS MEASURED DRAWDOWN IN FEET
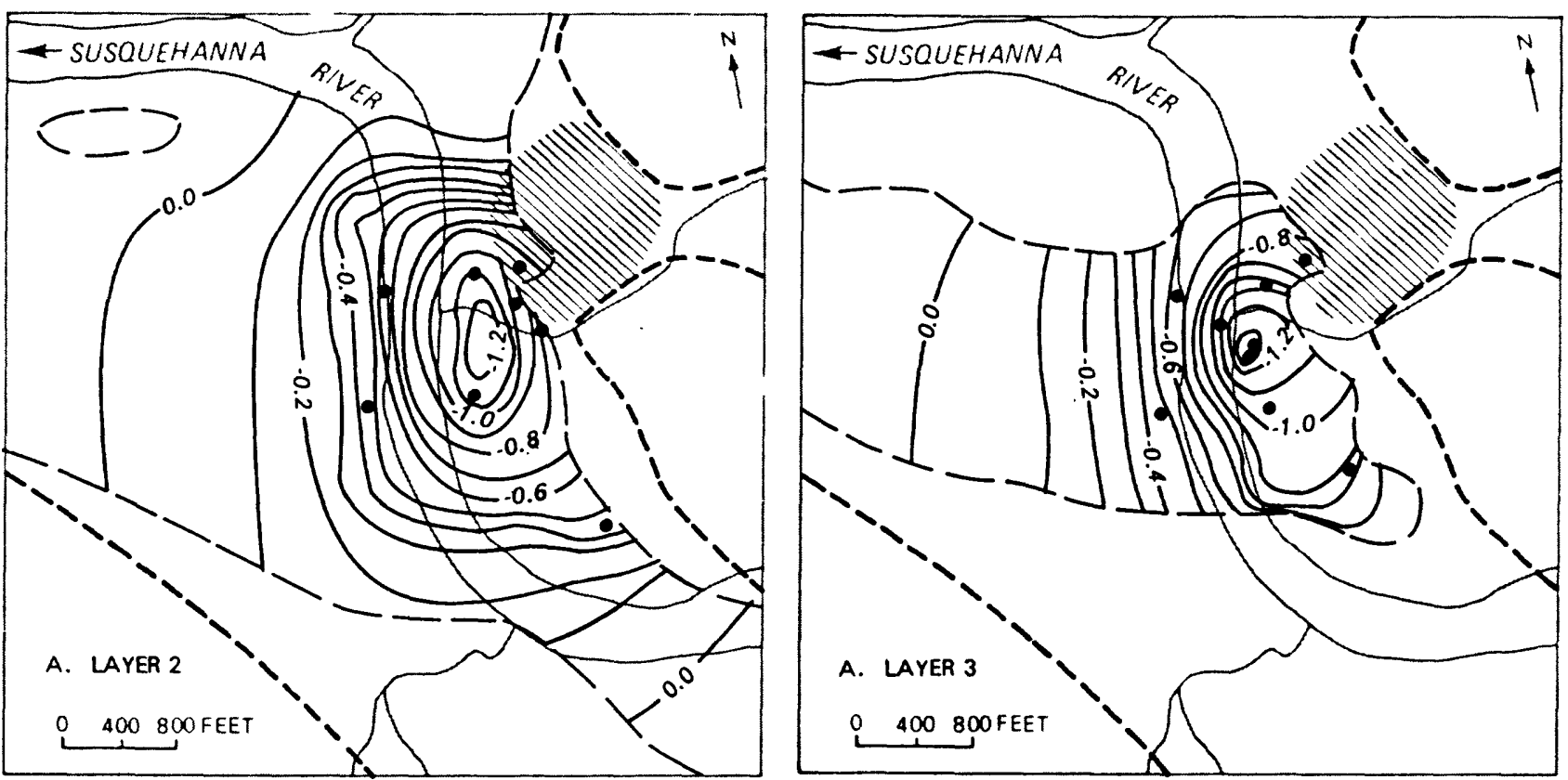

Figure 27.-- Distribution of model sensitivity to respective aquifer properties:

A. Base values of hydraulic conductivity (Kbase) in layers 2 and 3. 

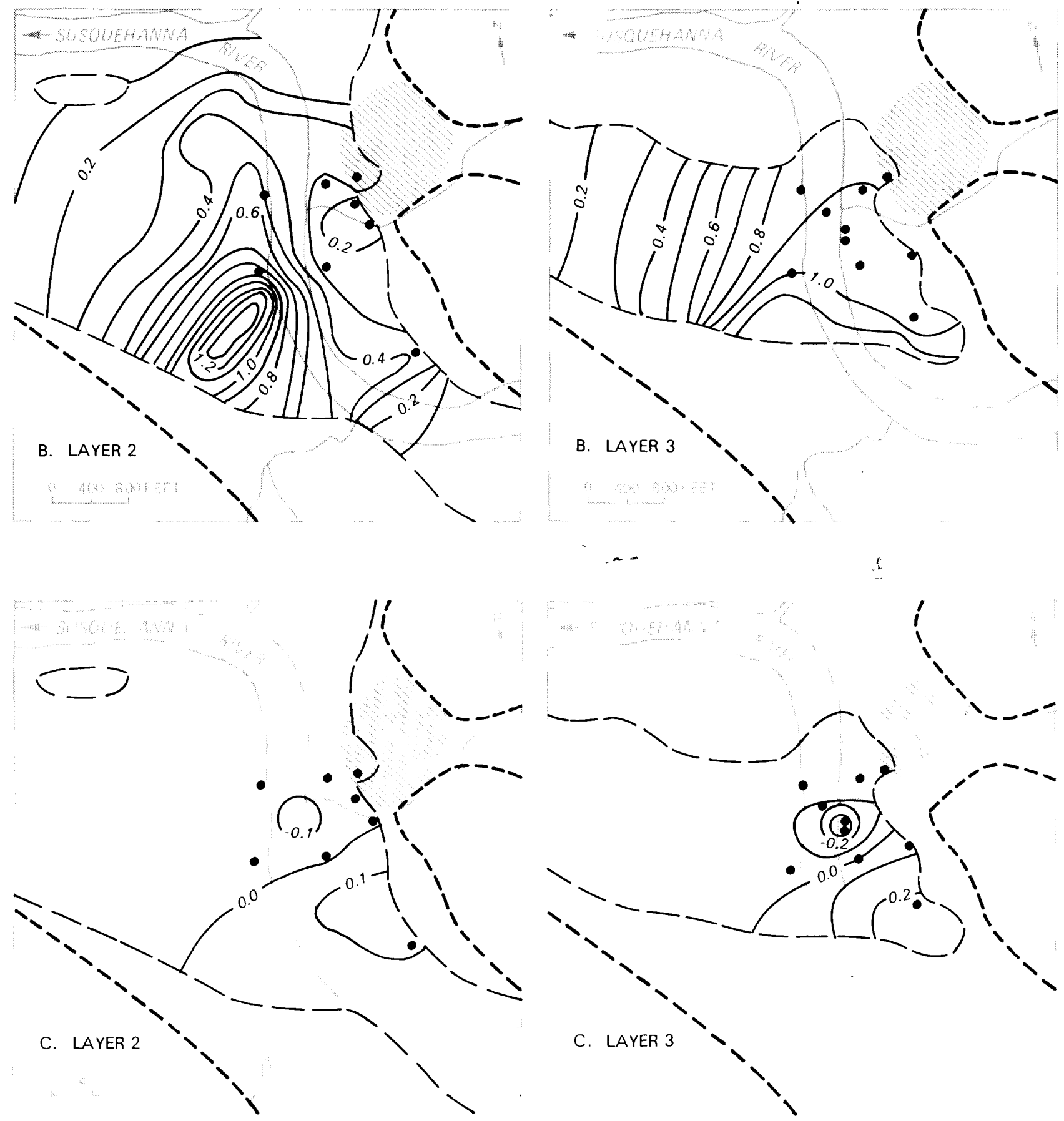

EXPLANATION

- OBSERVATION WELL

- - AQUIFER BOUNDARY IN LAYER 1

- $0.2-$ LINE OF EQUAL SENSITIVITY.

TILL BOUNDARY CONTOUR INTERVAL 0.1 FEET

NIII' CONSTRUCTION LANDFILL

Figure 27 (continued).--Distribution of model sensitivity to respective aquifer properties:

$B$. Anisotropy of upper part of aquifer $(K v 1)$ in layers 2 and 3.

C. Maximum hydraulic conductivity of aquifer $\left(K_{\max }\right)$ in layers 2 and 3. 


\section{Statistical Analysis}

Two assumptions upon which the nonlinear regression method is based are that (1) the model is correct, that is, the flow equation (eq. 9, p. 28) together with the zonation pattern and boundary conditions adequately represent the aquifer system, and (2) the residuals between observed heads and those computed from the set of estimated values can be considered a set of uncorrelated random variables with zero mean and constant variance. These assumptions can be checked indirectly by analyzing the distribution of residuals. In addition, if the residuals are normally distributed and the model is linear among parameters near the set of optimum values, then statistical techniques described by Cooley and Naff (1985) can be applied to determine confidence limits for the estimates of aquifer properties and the predicted heads. Normal probability plots can be used to test the assumption of normality, and Beale's measure can be calculated to indicate the degree of nonlinearity in the model (Cooley and Naff, 1985, pp. 314 and 361).

Analysis of residuals. Bias apparent in the drawdowns computed by the regression model (fig. 28) is less pronounced than in those computed by the calibration model (fig. 14). Much of the correlation among the residuals that remains can be explained by proximity to the pumped wells because drawdowns in the upper part of the aquifer are underpredicted (fig. 29A), while those near the production well screen in the lower part of the aquifer are overpredicted (fig. 29B). The bias in the regression results indicates that the assumption of model correctness is not strictly fulfilled. Therefore, parameter values and standard errors computed from the regression are only approximate. The regression results are still useful in illustrating the uncertainty in the calibrated model, however. Model bias may be reduced by incorporating additional parameters into the regression or by changing the zonation pattern used in the model.

Residuals were plotted on graphs to test the assumptions that they were uncorrelated and normally distributed. Normal probability plots were prepared for (1) the residuals, $e_{i} ;(2)$ three sets of uncorrelated, random normal deviates, $d_{i}$, with the same mean and variance as e; and (3) three sets of simulated residuals, $\mathrm{g}_{\mathrm{i}}$, with the same covariance structure as $\underline{e}$, following the procedure described by Cooley and Naff $(1985$, p. 318). The plots (fig. 30) are graphs of cumulative frequency, $\mathrm{F}_{\mathrm{i}}$, in relation to values of $\underline{e}, \underline{d}$ and $g$,

$$
\mathrm{F}_{\mathrm{i}}=\underset{(\mathrm{n}+1)}{\underline{\mathrm{m}}_{\mathrm{i}}} \mathrm{i}=1, \mathrm{n}
$$

where: $m_{i}$ is the number of values of e less than or equal to value of $e_{i}$; and

$n$ is the number of observations.

Four sets of values were computed for $\mathrm{d}$ and $\mathrm{g}$ by the FORTRAN 77 program RESAN (Cooley and Naff, 1985, p. 339).

The plots for $\mathrm{d}$ and $\mathrm{g}$ (figs. $30 \mathrm{~B}$ and $30 \mathrm{C}$ ) are similar, which indicates that the distribution of $\underline{e}$ is not greatly affected by correlation and unequal variance. The slope of the plot for e (fig. 30A) differs slightly from the average slope of plots of $\mathrm{g}$ (fig. 30C), however, which suggests that $\underline{\mathrm{e}}$ does not strictly conform to a normal distribution.

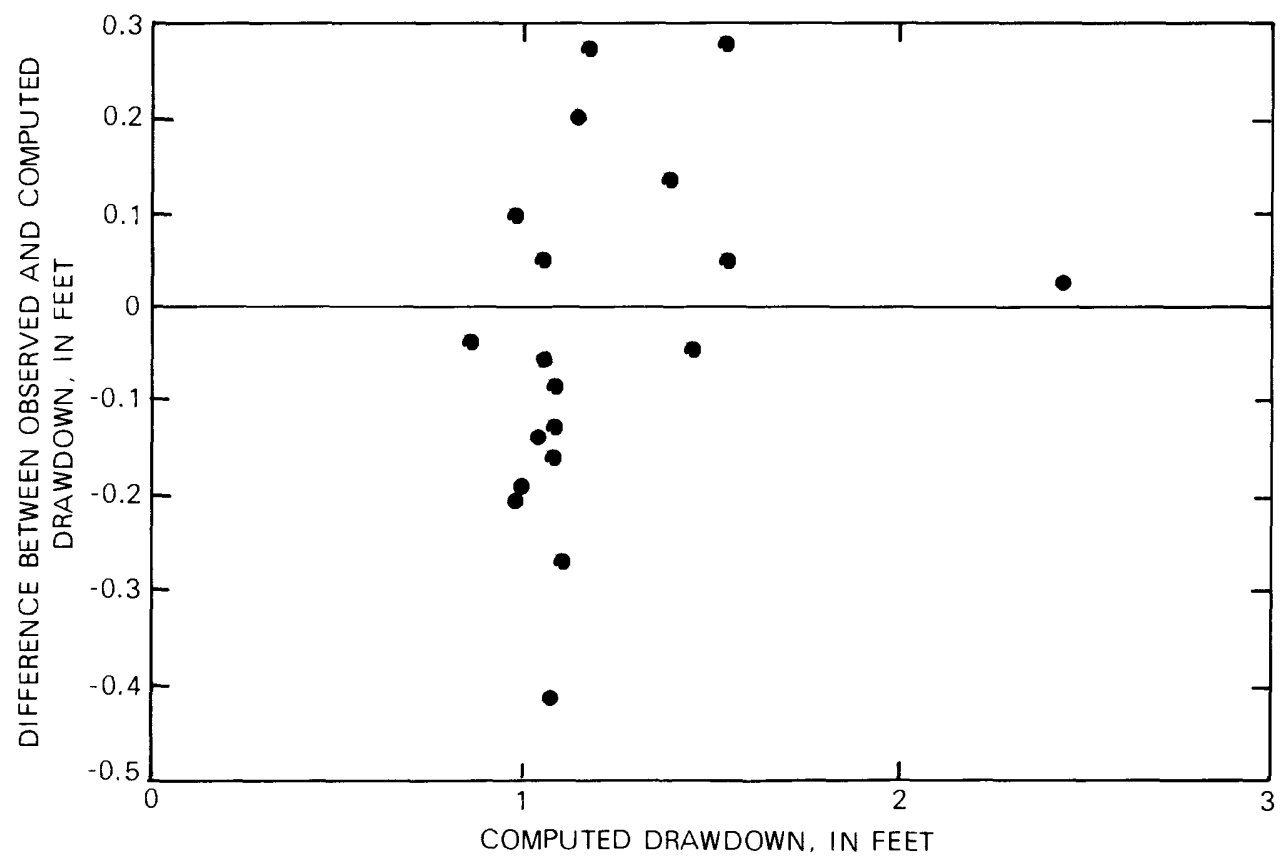

Figure 28.-- Difference between observed drawdowns and those computed from nonlinear regression values by transient-state simulation, plotted in relation to computed drawdowns. 


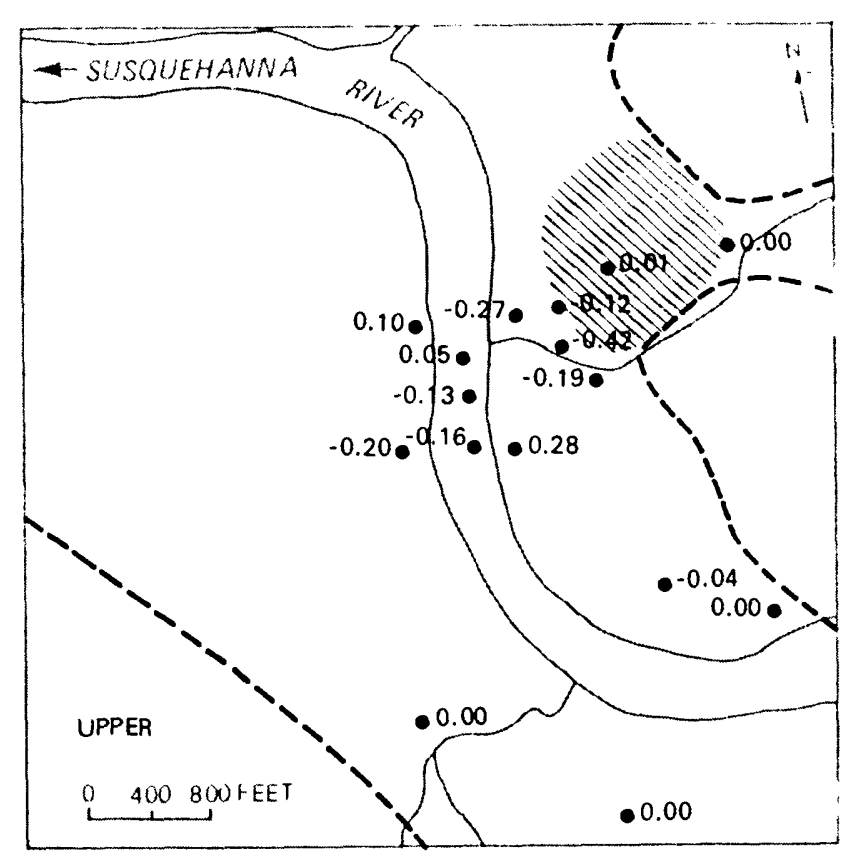

EXPLANATION

- - aquifer boundary IN LAYER 1

- TILL BOUNDARY

NIN CONSTRUCTION LANDFILL

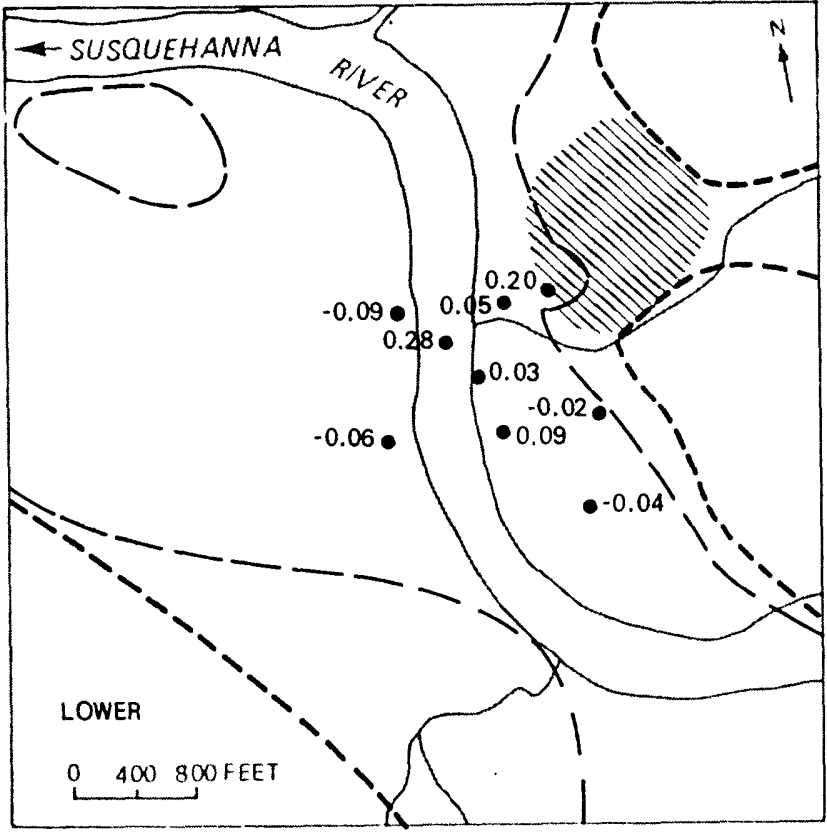

- 0.06 OBSERVATION WELL, NUMBER IS

DIFFERENCE BETWEEN OBSERVED

AND COMPUTED DRAWDOWN IN FEET

Figure 29.-- Difference between observed drawdowns and those computed from nonlinear regression values by transient-state simulation in the upper and lower parts of the aquifer

Beale's measure. The assumption of model linearity was tested by Cooley (1979) using Beale's measure to estimate the degree of model nonlinearity. The procedure entails solving the nonlinear model and a linearized version through use of several parameter sets $\underline{b}$ defined in the vicinity of the optimum values $\underline{b}^{\circ}$. These solutions are used to calculate Beale's measure $\left(\mathrm{N}_{b}^{\circ}\right)$, a ratio whose magnitude is related to the discrepancy between solutions obtained with the nonlinear and linearized models. Beale's measure is compared with two criteria (Cooley and Naff, 1985, p. 365):

If

$\mathrm{N}_{\mathrm{b}}^{\circ}>1 / \mathrm{F}_{\alpha}(\mathrm{p}, \mathrm{n}-\mathrm{p})$

where:

$F_{\alpha}(p, n-p) \quad$ is the upper $\alpha$ quantile of the $F$ distribution with $p$ and $n-p$ degrees of freedom,

then the model is too nonlinear to apply linear statistical techniques.

If

$$
\mathrm{N}_{\mathrm{b}}^{\circ}<0.01 / \mathrm{F}_{\alpha}(\mathrm{p}, \mathrm{n}-\mathrm{p})
$$

the model is effectively linear.
Beale's measure was computed by FORTRAN 77 program BEALE (Cooley and Naff, 1985, p. 374). A value of 0.27098 was obtained from drawdown distributions computed from 10 parameter sets $\underline{b}$ corresponding to maximum and minimum values of the five regression parameters. The parameter sets were selected at the edge of the 95-percent joint confidence region as suggested by Cooley and Naff (1985, p. 366) and calculated by equation 5.6-15 of Cooley and Naff (1985, p. 331). The value of the $F$ distribution at the 95 -percent joint confidence level with 5 and 14 degrees of freedom $\left(\mathrm{F}_{0.05}(5,14)\right)$ is 2.96 . Therefore, Beale's measure for the regression model $(0.27098)$ is below the upper criterion of 0.338 but above the lower criterion of 0.00338 . This suggests that some degree of nonlinearity is present in the model, so that confidence limits for the estimated values computed with standard statistical techniques will be approximate.

Confidence levels for regression-estimated values. Computation of confidence intervals for regression parameters is discussed by Cooley and Naff (1985, p. 330). Their method assumes that the model is correct and linear in the vicinity of the optimum set of values and that the residuals are uncorrelated and normally dis- 

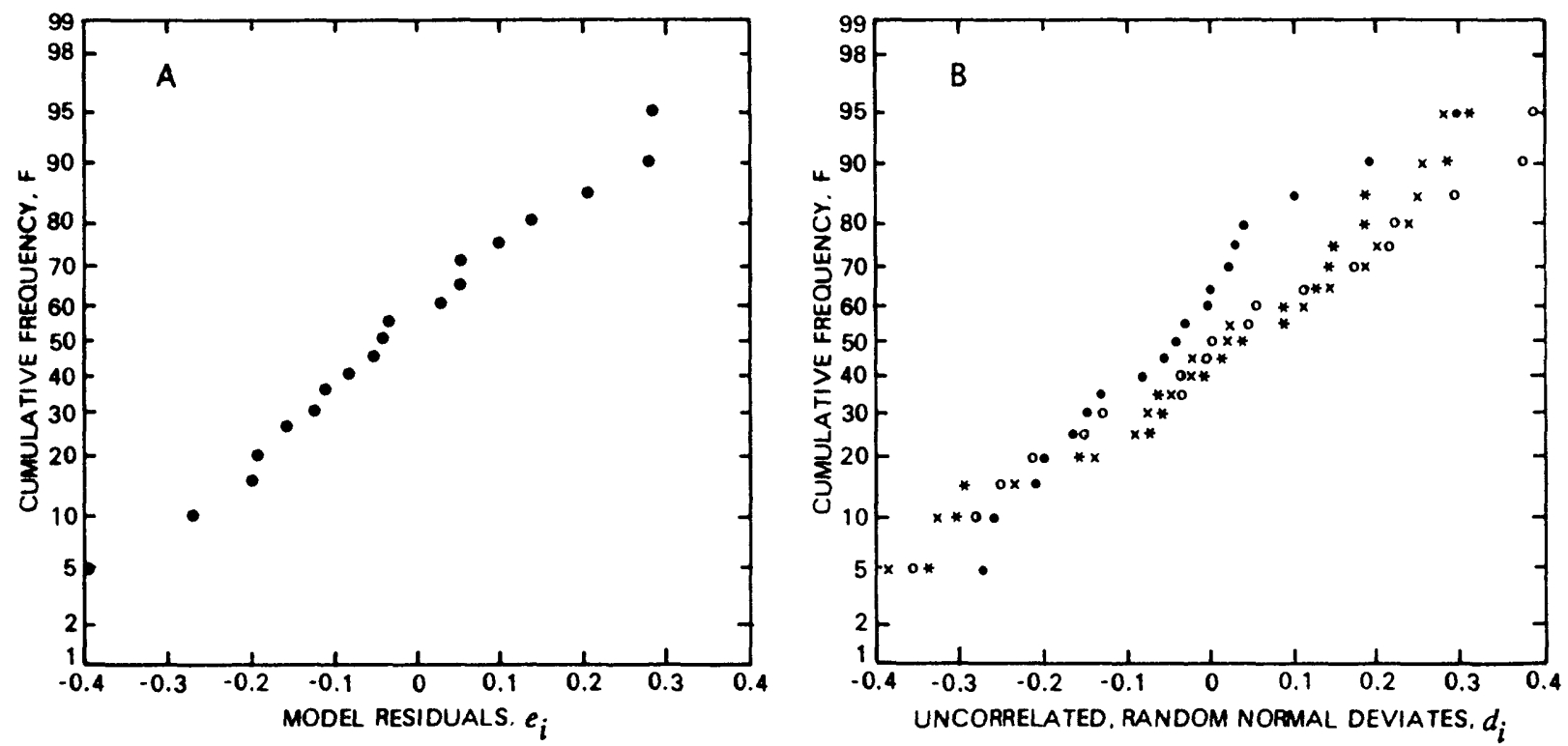

Figure 30.

Normal probability plots for residuals

A. Model residuals, $e_{i}$.

B. Uncorrelated, random normal deviates, $d_{i}$.

C. Simulated residuals, $g_{i}$.

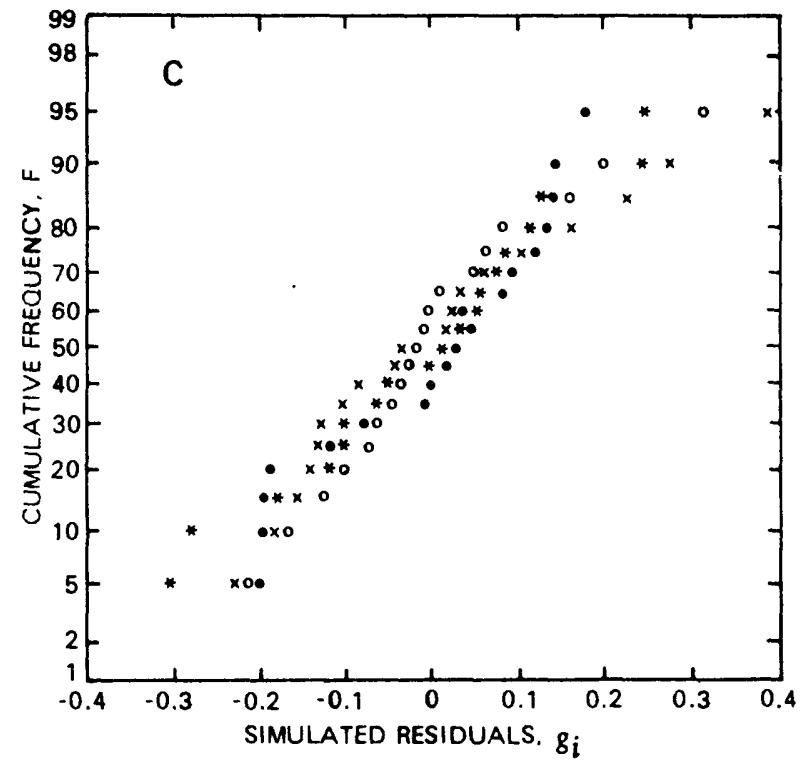

tributed. The assumption of linearity is not met by the regression model, and the bias in the residuals indicates that the model is only approximately correct. In addition, although the distribution of residuals appears to be uncorrelated, it may not strictly fulfill the assumption of normality. Therefore, confidence intervals were computed to illustrate the method of Cooley and Naff and to qualitatively describe the reliability of the estimated values.

Confidence intervals at the 95-percent confidence level were computed for each parameter individually and from the joint confidence region for the entire parameter set (table 7). Inspection of the confidence intervals indicates that values of anisotropy of the upper

part of the aquifer (Kv1) and hydraulic conductivity (Kbase) are constrained over relatively small ranges, whereas values of the maximum value of hydraulic conductivity (Kmax) may fall over a much larger range. Values for vertical hydraulic conductivity of the riverbed $(\mathrm{Kr})$ and the anisotropy of the lower part of the river (Kv2) are not well estimated, and the confidence intervals associated with them are large. The approximate nature of the linearized confidence region is indicated by the negative values of $\mathrm{Kr}$ and $\mathrm{Kv} 2$ included within the confidence region. The minimum lower boundary of these parameters is physically unrealistic, which suggests that the variance in these parameter values is overestimated, probably because the model is insensitive to the parameters. 
Table 7.--Values of aquifer properties estimated by regression and their confidence intervals at 95-percent level.

\begin{tabular}{|c|c|c|c|c|c|c|}
\hline $\begin{array}{l}\text { Aquifer } \\
\text { property }\end{array}$ & Symbol & $\begin{array}{l}\text { Estimated } \\
\text { value }\end{array}$ & & $\begin{array}{l}\text { Individual } \\
\text { confidence } \\
\text { interval }\end{array}$ & & $\begin{array}{l}\text { Joint } \\
\text { confidence } \\
\text { interval. }\end{array}$ \\
\hline $\begin{array}{l}\text { Vertical hydraulic } \\
\text { conductivity of } \\
\text { riverbed }(\mathrm{ft} / \mathrm{d})\end{array}$ & $\mathrm{Kr}$ & 0.002 & \pm & 0.090 & \pm & 0.160 \\
\hline \multicolumn{7}{|l|}{ Anisotropy: } \\
\hline $\begin{array}{l}\text { Upper aquifer } \\
\text { Lower aquifer }\end{array}$ & $\begin{array}{l}\mathrm{Kv1} \\
\mathrm{Kv} 2\end{array}$ & $\begin{array}{r}350 \\
2.0\end{array}$ & \pm & $\begin{array}{r}140 \\
97\end{array}$ & \pm & $\begin{array}{l}260 \\
170\end{array}$ \\
\hline \multicolumn{7}{|l|}{$\begin{array}{l}\text { Horizontal hydraulic } \\
\text { conductivity of } \\
\text { aquifer }(\mathrm{ft} / \mathrm{d}) \text { : }\end{array}$} \\
\hline $\begin{array}{l}\text { Value for zone } 7 \\
\text { in layer } 3\end{array}$ & $\mathrm{~K} \max$ & 13,000 & \pm & 12,000 & \pm & 22,000 \\
\hline $\begin{array}{l}\text { Base value for all } \\
\text { other zones }\end{array}$ & Kbase & 670 & \pm & 210 & \pm & 370. \\
\hline
\end{tabular}

\section{RELIABILITY OF ESTIMATED HYDRAULIC VALUES}

The values of aquifer properties estimated through model calibration (trial-and-error) and from nonlinear regression are summarized in table 8 . The hydraulic head measurements made during the study were sufficient to estimate the horizontal hydraulic conductivity of aquifer material (Kmax and Kbase) and vertical anisotropy of materials in the upper part of the aquifer (Kv1). Individual confidence intervals computed for these parameters (table 7) suggest that reliable estimates of values for Kbase and Kv1 were obtained with the regression method, whereas the value for Kmax was less reliable. The observed data were insufficient to estimate values for the remaining aquifer properties - vertical anisotropy of the lower aquifer (Kv2), storage coefficient and specific yield, and vertical hydraulic conductivity of the riverbed $(\mathrm{Kr})$.

No attempt was made to assess the effect of the zonation pattern used in the model on the estimated values, but the assumed pattern of a small zone of high hydraulic conductivity bounded laterally and above by material of lower hydraulic conductivity is supported by the simulation results. Other zonation patterns could be evaluated with repeated trials of the regression procedure. Sun and Yeh (1985) discuss an automated method for determining optimal zonation through a different inverse method.

\section{Alternative Parameter Sets}

The difference between the parameter sets obtained through trial-and-error and nonlinear regression can be measured with the "W" statistic defined by Cooley and Naff $(1985$, p. 328, eq. 5-6-17). A large value of $W$ relative to the value $\mathrm{F}_{\alpha}(\mathrm{p}, \mathrm{n}-\mathrm{p}$ ) (see eq. 14) indicates that the parameter sets differ at a significance level, $\alpha$. Application of the $\mathrm{W}$ statistic as a rigorous hypothesis test requires the assumptions that the model is correct and the residuals are uncorrelated, normally distributed random numbers. Because the model did not fully meet these assumptions, the W statistic indicates only qualitatively the differences between the parameter sets.

The value of $\mathrm{W}$ computed by comparing simulation results with the model calibration and nonlinear regression parameter sets (table 8 ) is 24.2. This $\mathrm{W}$ value is much larger than the value of 2.96 given by $\mathrm{F}_{0.05}(5,14)$, which indicates that the two sets differ considerably. Much of this apparent difference is due to the effect of a single parameter, Kmin, which was initially estimated through nonlinear regression and then held constant. If the parameter set estimated through model calibration is updated to include the value of Kmin estimated through nonlinear regression, the value of $\mathrm{W}$ computed with the two parameter sets is reduced to 2.80 . Therefore, the two sets actually are quite similar, except for the value of $\mathrm{Kmin}$.

\section{Riverbed Hydraulic Conductivity}

Measurements of hydraulic head were insufficient to estimate vertical hydraulic conductivity of the river- 
bed deposit $(\mathrm{Kr})$, although an upper bound of $0.1 \mathrm{ft} / \mathrm{d}$ seems reasonable from sensitivity analysis that arbitrarily assumed a riverbed thickness of $1 \mathrm{ft}$. The true thickness of the riverbed deposits is unknown but may be as much as $5 \mathrm{ft}$, which would increase the estimate of $\mathrm{Kr}$ to $0.5 \mathrm{ft} / \mathrm{d}$. Permeameter tests of core samples taken beneath the riverbed yielded a value of $0.001 \mathrm{ft} / \mathrm{d}$ for sediment of low permeability. The effective hydraulic conductivity of the riverbed deposits over a wide area is probably higher than this value because these materials are distributed in discontinuous layers separated by sand and gravel. Therefore, $\mathrm{Kr}$ is estimated to be between 0.5 and $0.001 \mathrm{ft} / \mathrm{d}$.

The vertical hydraulic conductivity of the riverbed limits river infiltration into the aquifer, and uncertainty regarding this value is the major limitation in applying the flow model to delineate the well-field catchment area. Sensitivity analysis showed that the rate of river infiltration to the well field and the size of the catchment area were highly sensitive to this parameter. Depending on the value of $\mathrm{Kr}$, the well-field catchment area could range from 0.2 to $0.5 \mathrm{mi}^{2}$, which represents 35 to 85 percent of the aquifer's surface area. The esti- mated volume of induced infiltration from the river could range from less than 10 to as much as 70 percent of the ground water pumped by the Kirkwood well field.

Values of riverbed hydraulic conductivity (Kr) estimated for this study area could be compared with those estimated for other areas with the following qualifications. (1) $\mathrm{Kr}$ values estimated through simulation are dependent on the assumed thickness of the riverbed deposit, which in the Kirkwood area is unknown but assumed to range from 1 to $5 \mathrm{ft}$. (2) The origin and type of materials that form the riverbed vary locally; values from the Kirkwood area may be most representative of wide channels (greater than $100 \mathrm{ft}$ ) in the Susquehanna watershed in New York State. (3) The Kirkwood study area may differ from other areas within the glaciated Northeast in that the Susquehanna River is relatively large, with a mean discharge of $3,000 \mathrm{ft}^{3} / \mathrm{s}$. Also, the river channel contains pools and riffles of differing hydraulic characteristics; therefore, the model estimate of $\mathrm{Kr}$ represents the average vertical hydraulic conductivity and reflects the permeability and density of preferential pathways beneath the riverbed.

Table 8.--Values of aquifer properties estimated through simulation of ground-water flow.

\begin{tabular}{|c|c|c|c|c|}
\hline $\begin{array}{l}\text { Aquifer } \\
\text { property }\end{array}$ & Symbol & $\begin{array}{l}\text { Initial } \\
\text { estimate }\end{array}$ & $\begin{array}{l}\text { Model } \\
\text { cali- } \\
\text { bration }\end{array}$ & $\begin{array}{l}\text { Nonlinear } \\
\text { regression }\end{array}$ \\
\hline $\begin{array}{l}\text { Vertical hydraulic } \\
\text { conductivity of } \\
\text { riverbed }(\mathrm{ft} / \mathrm{d})\end{array}$ & $\mathrm{Kr}$ & 5.0 & 0.1 & 0.002 \\
\hline Anisotropy: & & & & \\
\hline $\begin{array}{l}\text { Upper aquifer } \\
\text { Lower aquifer }\end{array}$ & $\begin{array}{l}\text { Kv1 } \\
\text { Kv2 }\end{array}$ & $\begin{array}{l}100 \\
100\end{array}$ & $\begin{array}{l}250 \\
125\end{array}$ & $\begin{array}{r}350 \\
2\end{array}$ \\
\hline $\begin{array}{l}\text { Horizontal hydraulic } \\
\text { conductivity of } \\
\text { aquifer (ft/d): }\end{array}$ & & & & \\
\hline $\begin{array}{l}\text { Maximum value } \\
\text { Base value } \\
\text { Minimum value }\end{array}$ & $\begin{array}{l}\text { Kmax } \\
\text { Kbase } \\
\text { Kmin }\end{array}$ & $\begin{array}{l}2,000 \\
2,000 \\
2,000\end{array}$ & $\begin{array}{r}10,000 \\
500 \\
500\end{array}$ & $\begin{array}{r}13,000 \\
670 \\
210\end{array}$ \\
\hline $\begin{array}{l}\text { Model error: } \\
\text { Root mean square } \\
\text { Sum of squared } \\
\text { error }\end{array}$ & $\begin{array}{l}\text { RMS } \\
\text { SSE }\end{array}$ & .77 & .17 & .12 \\
\hline
\end{tabular}




\section{DATA REQUIRED FOR ESTIMATION OF HYDRAULIC VALUES}

This study showed that simulation models can be used to estimate values for hydraulic properties if (1) the simulation is sensitive to those properties, and (2) the observed heads are measured at locations corresponding to areas in the model that are sensitive to those properties. Heads need to be measured at several depths in the aquifer to estimate vertical anisotropy, and directly beneath the riverbed to estimate riverbed hydraulic conductivity.

\section{Timing of Measurements}

The timing of measurements used to calibrate transient-state simulations also is important. Estimation of storage coefficient and specific yield requires measurement of early and late parts of the drawdown curve during an aquifer test (see fig. 21). Drawdowns generally need to be measured during the first minute of the aquifer test to define the early part of the curve, and the test should be continued long enough to define the later part. Drawdown-through-time data could be incorporated into the nonlinear regression by computing model sensitivity at each time step corresponding to a drawdown measurement. An inverse approach for estimating hydraulic properties under transient conditions is discussed by Carrera and Neuman (1986).

The steady-state simulations were found to be more sensitive than transient-state simulations to changes in riverbed hydraulic conductivity $(\mathrm{Kr})$. Changes in releases from storage compensated for changes in riverinfiltration rate in transient-state simulations and decreased the model sensitivity to this parameter. Model sensitivity in transient-state simulations would increase for longer pumping periods with declining releases from storage. Steady-state simulations could be used to calibrate the model to prepumping and postpumping conditions, but results of these simulations would be more affected by model boundaries than those of transient-state simulations.

\section{Alternative Methods}

Results of sensitivity analyses with steady-state simulations suggest that the estimate of $\mathrm{Kr}$ could be improved if the rate of infiltration through the riverbed were known. Loss of water from the Susquehanna River through infiltration cannot be determined directly from streamflow measurements because river flow exceeds rate of infiltration at this site by at least 2 orders of magnitude. Infiltration rates could perhaps be estimated, however, by other techniques currently under study (Lyford, 1986). These include mass balance computations based on measured concentrations of environmental isotopes in river, aquifer, and well water (Dysart, 1988), and determination of vertical ground-water velocities by comparison of diurnal fluctuations of temperature (Lapham, 1989) or dissolved oxygen in water samples from the river and riverbed.

\section{UTILITY OF SENSITIVITY AND NONLINEAR REGRESSION ANALYSES}

Both the sensitivity analysis and nonlinear regression indicated the model to be sensitive to the same parameters. The regression method gave an estimate of the anisotropy of the upper part of the aquifer, while the anisotropy of both the upper and lower parts were varied together as a single parameter in the sensitivity analysis. The sensitivity analysis provided an upper limit on the value of vertical hydraulic conductivity of the riverbed, however, which was not identified by the regression.

\section{Reduction of Model Error}

The steps involved in estimating aquifer properties during this study may be instructive in developing methods for subsequent simulation studies. Model error, measured as RMS difference and sum-of-squared errors, for the 61 simulations run during model calibration and the 19 iterations of the nonlinear regression ${ }^{1}$, is plotted in figure 31 . Model calibration required about 2

\footnotetext{
${ }^{1}$ Iterations of the nonlinear regression each required six simulation runs.
}

months of effort and the regression required an additional month. An additional 26 simulations were run for the sensitivity analysis. Simulations made during the first half of model calibration show a trend of decreasing model error and finally obtained a set of values that is fairly close to that obtained at the end of the calibration. (A decreased grid spacing adopted at simulation 31 produced a slight increase in model error in subsequent simulations.) In contrast, simulations made during the latter half of the calibration show no trend in model error. These simulations investigated the effects of changing two or more parameter values simultaneously, but the results were difficult to interpret. The final set of simulations, based on the nonlinear regression, generally show a steady decrease in model error.

The second half of calibration provided little improvement in model error, and the most efficient approach would have been to follow the first 30 simulations immediately by the nonlinear regression. This sequence combined with a fully-automated regression procedure would have saved about 1.5 months of effort. Trial-and-error calibration was necessary to develop the 


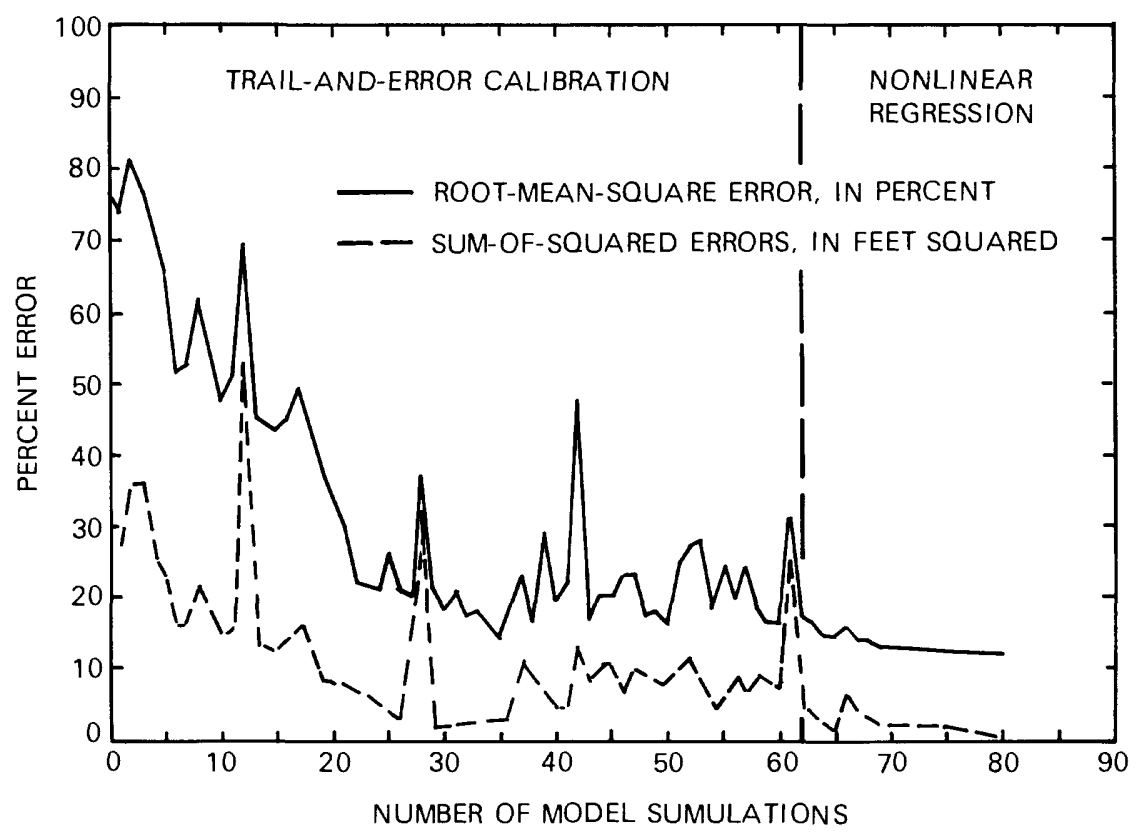

Figure 31.--Model error during model calibration and nonlinear regression.

zonation patuin and provide familiarity with mulet response to changes in hydraulic values. The nonlinear regression, while refining the parameter estimates, provided information on the correlation among the parameters. The regression also identified the parameters to which the model was sensitive and estimated the uncertainty associated with the values obtained for each of them. The model response to selected parameters could be compared directly through the corresponding sensitivities.

\section{Application of Nonlinear Regression}

The modified nonlinear regression method was implemented by a semiautomated procedure with the McDonald-Harbaugh model and the FORTRAN 77 program MULREG (appendix A). Data files required by the ground-water flow model were generated by software developed for the study, but initiation of simulation runs remained under manual control. The 19 iterations of the Gauss-Newton method that were completed required more than 100 simulation runs and about 50 hours of processing time on a PRIME $750^{1}$ computer. Only one zonation pattern was analyzed with the method because of the excessive time require- nicnts of the semiautomated procedure. A computer program for estimating parameter values through nonlinear regression has been developed for use with the U.S. Geological Survey finite-difference model used in this study (M. C. Hill, U.S. Geological Survey, written commun., 1990). With this new procedure, convergence of the nonlinear regression can be obtained in a single weekend run or in several overnight runs. It is therefore possible to examine different zonation patterns or sets of values within the time constraints of a typical study.

Inverse methods such as the nonlinear regression procedure should be incorporated into simulation studies along with the traditional trial-and-error approach. Some trial-and-error calibration is necessary to obtain information on the influence of boundary conditions and hydraulic properties on model response and to develop a preliminary zonation pattern for model parameters. Inverse methods can then be applied to estimate the values and the uncertainty and to test the effects of different zonation patterns. Inverse methods can also be used at the beginning of a modeling study to identify sensitive areas in the model where data need to be collected.

\footnotetext{
${ }^{1}$ Use of brand names in this report is for identification purposes only and does not constitute endorsement by the U.S. Geological Survey.
} 


\section{SUMMARY AND CONCLUSIONS}

The aquifer along the Susquehanna River near Kirkwood, N.Y., was selected as part of the study of the Northeastern Glacial Valleys Aquifer System of the U.S. Geological Survey's Regional Aquifer System Analysis (RASA) program to study hydraulic properties of a riverbed and aquifer system near a large river in which pumping-induced infiltration from the river cannot be measured directly. Hydraulic conductivity of riverbed and aquifer material were estimated through a previously developed simulation model of groundwater flow. The reliability of these estimates was assessed through sensitivity analysis and nonlinear regression.

The aquifer consists of a 30- to 70-ft thickness of sand and gravel underlain by sand and silt and bounded below and laterally by till. Discontinuous layers of compact, silty sand and gravel are interspersed throughout the aquifer but are most common in the upper 20 to $30 \mathrm{ft}$.

The aquifer is in hydraulic connection with the Susquehanna River, and records of ground-water levels and temperatures indicate that the river significantly affects ground-water flow. Production wells in the towns of Kirkwood and Conklin now capture ground water that previously discharged to the river and induce infiltration of river water into the aquifer.Vertical hydraulic conductivity of the riverbed materials limits the rate of river infiltration for a given hydraulic gradient. Samples of riverbed material contain discontinuous layers of silty sand and gravel, similar to those within the aquifer material, that restrict the vertical movement of river water into the aquifer. The vertical hydraulic conductivity of these layers, estimated by constant-head, triaxial permeameter tests, is $10^{-3} \mathrm{ft} / \mathrm{d}$.

A three-dimensional finite-difference model was calibrated through trial and error to simulate an aquifer test in the Kirkwood well field in October 1984. The overall match between observed and predicted drawdowns was close, and the root-mean-square error of model results was 17 percent. Analysis of residuals indicated, however, that the model was biased in that drawdowns in the upper aquifer layers were underestimated and those in the lower layers were overestimated. Hydraulic properties estimated through trial-and-error calibration were as follows:

1. Horizontal hydraulic conductivity

500 to $10,000 \mathrm{ft} / \mathrm{d}$

2. Anisotropy (ratio of horizontal to vertical hydraulic conductivity)

upper aquifer

lower aquifer
3. Vertical hydraulic

conductivity of riverbed

0.1 to $0.5 \mathrm{ft} / \mathrm{d}$

Sensitivity analysis was used to investigate the effect of differing values of hydraulic properties on residual error (differences between simulated and measured water levels). A sensitivity analysis indicated that a narrow range of anisotropy values gave the smallest residual error in simulated drawdowns. Residual error increased when the maximum hydraulic conductivity in the aquifer was lowered to values less than 5,000 feet per day. Residual error also was large for high values of vertical hydraulic conductivity of the riverbed, but decreased to a constant amount for values less than 0.1 feet per day. Residual error was relatively insensitive to changes in the storage coefficient and specific yield. Infiltration from the river to the Kirkwood well field and the size of catchment area predicted by steady-state simulations were most sensitive to the vertical hydraulic conductivity of the riverbed.

A nonlinear regression method was modified by approximating the sensitivity matrix with a perturbation technique. The modified method was applied to the simulation model to obtain an optimum set of hydraulic properties and to compute the variance of the estimated values. The set of values obtained through the regression reduced the root-mean-square error from 17 to 12 percent and also reduced the model bias.

Results of the nonlinear regression indicated that transient-state simulations were sufficiently sensitive to estimate values of hydraulic conductivity of the aquifer (210 to $13,000 \mathrm{ft} / \mathrm{d}$ ) and the anisotropy ratio of the upper part of the aquifer (350:1). Values obtained through trial-and-error calibration fell within the 95-percent confidence intervals computed for these parameters. Anisotropy of the lower part of the aquifer could not be estimated because the vertical head gradient within the lower part was not measured. Transient-state simulations were relatively insensitive to the vertical hydraulic conductivity of the riverbed because releases from storage reduced the influence of river infiltration during the simulated aquifer test.

The vertical hydraulic conductivity of the riverbed was estimated to be 0.5 to $0.001 \mathrm{ft} / \mathrm{d}$. Uncertainty regarding this value is the major limitation in applying the flow model to delineate the well-field catchment area and to compute the amounts of water entering the pumped well from the river and adjacent areas. Comparison of these values with those obtained in similar areas elsewhere should consider (1) the assumed thickness of the riverbed deposit, and (2) the origin and type of materials that form the riverbed.

Simulation models can be used to estimate hydraulic properties if the models are sensitive to the properties and if the observed data are obtained at loca- 
tions corresponding to areas in the model that are sensitive to the properties. Observations at differing time intervals are necessary to calibrate storage terms used in transient-state simulations. Steady-state simulations are more sensitive than transient-state simulations to the vertical hydraulic conductivity of the riverbed and to model boundaries.

The development of simulation models would benefit from use of estimation techniques, such as nonlinear regression, together with trial-and-error calibration and sensitivity analysis. Estimation techniques are useful for investigating the interactions between parameters and for quantifying model sensitivities. The distribution of model sensitivity can be used to identify areas within model boundaries where data are needed to estimate hydraulic properties.

\section{REFERENCES CITED}

Carrera, Jesus, and Neuman, S. P., 1986, Estimation of aquifer parameters under transient and steady-state conditions: (1) maximum likelihood method incorporating prior information, (2) uniqueness stability and solution algorithms, (3) application to synthetic and field data: Water Resources Research, v. 22, no. 2, p. 199-242.

Coates, D. R., 1966, Till shadows on hills: Science, v. 152, no. 3729 , p. $1617-1619$.

ed., 1973, Glacial geology of the Binghamton-westem Catskill region: State University of New York at Binghamton, N.Y., Publications in Geomorphology, contribution no. 3,80 p.

Cooley, R. L., 1977, A method of estimating parameters and assessing reliability for models of steady-state ground-water flow: (1) theory and numerical properties: Water Resources Research, v. 13, no. 2, p. 318-324.

1979, A method of estimating parameters and assessing reliability for models of stcady-state ground-water flow: (2) application of statistical analysis: Water Resources Research, v. 15, no. 3, p. 603-617.

Cooley, R. L., and Naff, R. L., 1985, Regression modeling of ground-water flow: U.S. Geological Survey Open-File Report 85-180,450 p.

Dysart, J. E., 1988, Use of oxygen-18 and deuterium massbalance analysis to evaluate induced recharge to stratifieddrift aquifers in Randall, A. D., and Johnson, A. I., eds., Regional Aquifer System of the United States, the Northeast Glacial Aquifers: Bethesda, MD, American Water Resources Association, Monograph Series no. 11, p. 133-153.

Haeni, F. P., 1978, Computer modeling of ground-water availability in the Pootatuck River valley, Newton, Connecticut: U.S. Geological Survey Water-Resources Investigations Report 78-77, 64 p.

Harrison, J. E., 1966, Proglacial drainage evolution and deglaciation of the Great Bend Region, Pa. and N.Y.: Binghamton, N.Y., State University of New York, M. A. thesis, 71 p.

Lapham, W. W., 1989, Use of temperature profiles beneath streams to determine rates of vertical ground-water flow of vertical hydraulic conductivity: U.S. Geological Survey Water Supply Paper 2337, 35 p.
Leopold, L. B., Wolman, M. G., and Miller, J. P., 1964, Fluvial processes in Geomorphology: San Francisco, Calif., W. H. Freeman and Co., $522 \mathrm{p}$.

Lounsbury, Clarence, Hasty, A. H., Kinsman, D. F., and Baran, J. H., 1932, Soil survey of Broome County, New York: U.S. Department of Agriculture, Bureau of Chemistry and Soils, $40 \mathrm{p}$.

Lyford, F. P., 1986, Northeast glacial regional aquifer-system study in Sun, R. J., ed. Regional aquifer-system analysis program of the U.S. Geological Survey, Summary of projects 1978-84: U.S. Geological Survey Circular 1002, 264 p.

Lyford, F. P., Dysart, J. E., Randall, A. D., and Kontis, A. L., 1984, Glacial aquifer systems in the northeastem United States--a study plan: U.S. Geological Survey Open-File Report 83-928, 33 p.

MacNish, R. D., and Randall, A. D., 1982, Stratified-drift aquifers in the Susquehanna River basin, New York: New York State Department of Environmental Conservation, Bulletin $75,68 \mathrm{p}$.

McDonald, M. G., and Harbaugh, A. W., 1988, A modular threedimensional finite-difference ground-water flow model: U.S. Geological Survey Techniques of Water-Resources Investigations, Book 6, Chapter A1, 586 p.

Neuman, S. P., 1973, Calibration of distributed parameter ground-water flow models viewed as a multiple-objective decision process under uncertainty: Water Resources Research, v. 9, no. 4, p. 1006-1021.

1975, Analysis of pumping test data from anisotropic unconfined aquifers considering delayed gravity response: Water Resources Rescarch, v. 11, no. 2, p. 329-347.

Randall, A. D., 1972, Records of wells and test borings in the Susquehanna River basin, New York: New York State Department of Environmental Conservation, Bulletin 69, $92 \mathrm{p}$.

1977, The Clinton Street-Ballpark Aquifer in Binghamton and Johnson City, New York: New York State Department of Environmental Conservation, Bulletin 77, 87 p.

1978, A contribution to late Pleistocene stratigraphy of the Susquehanna River valley of New York: Empire State Geogram, v. 14, no. 2, p. 2-16. 


\section{REFERENCES CITED (continued)}

Randall, A. D., 1986, Aquifer model of the Susquehanna River valley in southwestern Broome County, New York: U.S. Geological Survey Water-Resources Investigations Report 85-4099, $38 \mathrm{p}$.

Randall, A. D., and Coates, D. R., 1973, Stratigraphy of glacial deposits in the Binghamton area, in Coates, D. R., ed., Glacial geology of the Binghamton-western Catskill region: State University of New York at Binghamton, Publications in Geomorphology, contribution no. 3, p. 40-55.

Reilly, T. E., Franke, O. L, and Bennett, G. D., 1984, The principle of superposition and its application in ground-water hydraulics: U.S. Geological Survey Open-File Report 84459, $36 \mathrm{p}$.

Sun, NeZheng, and Yeh, W. W-G, 1985, Identification of parameter structure in ground-water inverse problem: Water Resources Research, v. 21, no. 6, p. 869-883.
U.S. Army Corps of Engineers, 1982, Nonstructural flood protection study--Towns of Conklin, Kirkwood, and Erwin, New York: Baltimore, Md., U.S. Army Corps of Engineers, Supporting Documentation of Baltimore District, $199 \mathrm{p}$.

Waller, R. M., and Finch, A. J., 1982, Atlas of eleven selected aquifers in New York: U.S. Geological Survey Open-File Report 82-553, $255 \mathrm{p}$.

Yager, R. M., 1986, Simulation of ground-water flow and infiltration from the Susquehanna River to a shallow aquifer at Kirkwood and Conklin, Broome County, New York: U.S. Geological Survey Water-Resources Investigations Report $86-4123,70 \mathrm{p}$.

Yeh, W. W-G, 1986, Review of parameter identification procedures in ground-water hydrology-The inverse problem: Water Resources Research, v. 22, no. 2, p. 95-108. 


\section{APPENDIX \\ FORTRAN 77 LISTING OF COMPUTER PROGRAM MULREG}

The computer program MULREG was written in FORTRAN 77 by R. L. Cooley, U.S. Geological Survey, Denver, Colo., to solve the set of normal equations derived through the development of the nonlinear regression method. This development is described in Cooley and Naff (1985, p. 141-170), and the normal equations are defined therein by equation 3.3-12 on page 144 .

This appendix includes a listing of the program and a sample of the program output generated from the parameter values listed in table 4 . The data required as program input and the values computed by the program are listed below.

Table A-1.--Input and output data used in computer program MULREG

\begin{tabular}{|c|c|}
\hline \multicolumn{2}{|r|}{ Input } \\
\hline Variables & Definition \\
\hline$Y_{n}$ & measured hydraulic head \\
\hline$w_{n}$ & $\begin{array}{l}\text { reliability weights assigned } \\
\text { to measured values of } \\
\text { hydraulic head }\end{array}$ \\
\hline$F_{n}$ & $\begin{array}{l}\text { hydraulic head computed } \\
\text { by ground-water flow } \\
\text { model }\end{array}$ \\
\hline $\mathrm{B}_{\mathrm{p}}$ & estimated parameters \\
\hline$x_{\text {pxn }}$ & $\begin{array}{l}\text { sensitivity matrix computed } \\
\text { by perturbation }\end{array}$ \\
\hline \multicolumn{2}{|r|}{ Output } \\
\hline Variables & Definition \\
\hline $\mathrm{BNEW}_{\mathrm{p}}$ & $\begin{array}{l}\text { new estimates of } \\
\text { parameter values }\end{array}$ \\
\hline $\mathrm{COV}_{\mathrm{pxp}}$ & covariance matrix \\
\hline $\mathrm{COR}_{\mathrm{pxp}}$ & correlation matrix \\
\hline VAR & error variance \\
\hline
\end{tabular}

$\mathrm{n}=$ number of observations

$\mathrm{p}=$ number of parameters 


\section{APPENDIX A. PROGRAM LISTING}

$\mathrm{C}$

C

C

C

2 FORMAT $(2 I 5,3 F 10.0$, I5)

4 FORMAT (1H1,36HNO. OF OBSERVATIONS (NOBS) ----- = , I7

$\$ / 1 \mathrm{H}, 36 \mathrm{HNO}$. OF PARAMETERS (NPAR) ------ = , I7

$\$ / 1 \mathrm{H}, 36 \mathrm{HMAX}$. PARAMETER CORRECTION (DMAX) $=, \mathrm{G} 11.5$

$\$ / 1 \mathrm{H}, 36 \mathrm{HSEARCH}$ DIR. ADJUSTMENT PAR. (CSA) $=, \mathrm{G} 11.5$

$\$ / 1 \mathrm{H}, 36 \mathrm{HCLOSURE}$ CRITERION (TOL) --.----- $=$, G11.5

$\$ / 1 \mathrm{H}, 36$ HMAXIMUM NO. OF ITERATIONS (ITMX) $=$, I7)

6 FORMAT (8F10.0)

8 FORMAT $(1 \mathrm{H} 0,17 \mathrm{X}, 37 \mathrm{HOBSERVED} \mathrm{VALUES} \mathrm{OF} \mathrm{DEPENDENT} \mathrm{VARIABLE}$

$\$ / 1 \mathrm{H}, 3(4 \mathrm{X}, 3 \mathrm{HNO} ., 11 \mathrm{X}, 1 \mathrm{HY}, 5 \mathrm{X}))$

10 FORMAT (1H0,26X, 19HRELIABILITY WEIGHTS

$\$ / 1 \mathrm{H}, 3(4 \mathrm{X}, 3 \mathrm{HNO} ., 11 \mathrm{X}, 1 \mathrm{HW}, 5 \mathrm{X}))$

12 FORMAT (1H0,21X, 29HINITIAL REGRESSION PARAMETERS

$\$ / 1 \mathrm{H}, 3(4 \mathrm{X}, 3 \mathrm{HNO} ., 11 \mathrm{X}, 1 \mathrm{HB}, 5 \mathrm{X}))$

14 FORMAT $(1 \mathrm{H} 0,16 \mathrm{HITERATION}$ NO. $=, I 5 / 1 \mathrm{H}, 6 \mathrm{HRSQ}=, \mathrm{G} 11.5$

$\$, 2 \mathrm{X}, 6 \mathrm{HDET}=, \mathrm{G} 11.5 / 1 \mathrm{H}, 6 \mathrm{HAMP}=, \mathrm{G} 11.5,2 \mathrm{X}, 5 \mathrm{HAP}=, \mathrm{G} 11.5$

$\$, 2 \mathrm{X}, 6 \mathrm{HDMX}=, \mathrm{G} 11.5$

$\$ / 1 \mathrm{H}, 42 \mathrm{HCURRENT}$ ESTIMATES OF REGRESSION PARAMETERS)

16 FORMAT $((1 \mathrm{H}, 10(\mathrm{G} 11.5,2 \mathrm{X})))$

18 FORMAT (1H0,41HVARIANCE-COVARIANCE MATRIX FOR PARAMETERS)

20 FORMAT ( 1 H0, 33HCORRELATION MATRIX FOR PARAMETERS)

22 FORMAT (1H0, 17HERROR VARIANCE = , G11.5)

24 FORMAT $(1 \mathrm{H} 0,17 \mathrm{X}, 37 \mathrm{HCOMPUTED}$ VALUES OF DEPENDENT VARIABLE

$\$ / 1 \mathrm{H}, 3(4 \mathrm{X}, 3 \mathrm{HNO},, 11 \mathrm{X}, 1 \mathrm{HE}, 5 \mathrm{X}))$

26 FORMAT (1H0,27X, 18HWEIGHTED RESIDUALS

$\$ / 1 \mathrm{H}, 3(4 \mathrm{X}, 3 \mathrm{HNO} ., 11 \mathrm{X}, 1 \mathrm{HR}, 5 \mathrm{X}))$

28 FORMAT (1H0, 18HSENSITIVITY MATRIX)

C NPD $=20$

C

C

C

C DEFINE NUMBER OF ROWS DIMENSIONED FOR $X$

READ $(5,2)$ NOBS, NPAR, DMAX, CSA, TOL, ITMX

WRITE $(6,4)$ NOBS, NPAR, DMAX, CSA, TOL, ITMX READ OBSERVATIONS OF DEPENDENT VARIABLE

$\operatorname{READ}(5,6) \quad(Y(K), K=1, N O B S)$

WRITE $(6,8)$

CALI PRTOT $(Y, N O B S, 1,0)$

$$
\text { READ RELIABILITY WEIGHTS }
$$

$\operatorname{READ}(5,6) \quad(W(K), K=1, N O B S)$

WRITE $(6,10)$

CALL PRTOT $(W$, NOBS, 1,0$)$

READ INITIAL PARAMETER VALUES

$\operatorname{READ}(5,6) \quad(B(K), K=1, \operatorname{NPAR})$

WRITE $(6,12)$

CALL PRTOT (B, NPAR, 1, 0) 
APPENDIX A. PROGRAM LISTING (continued)

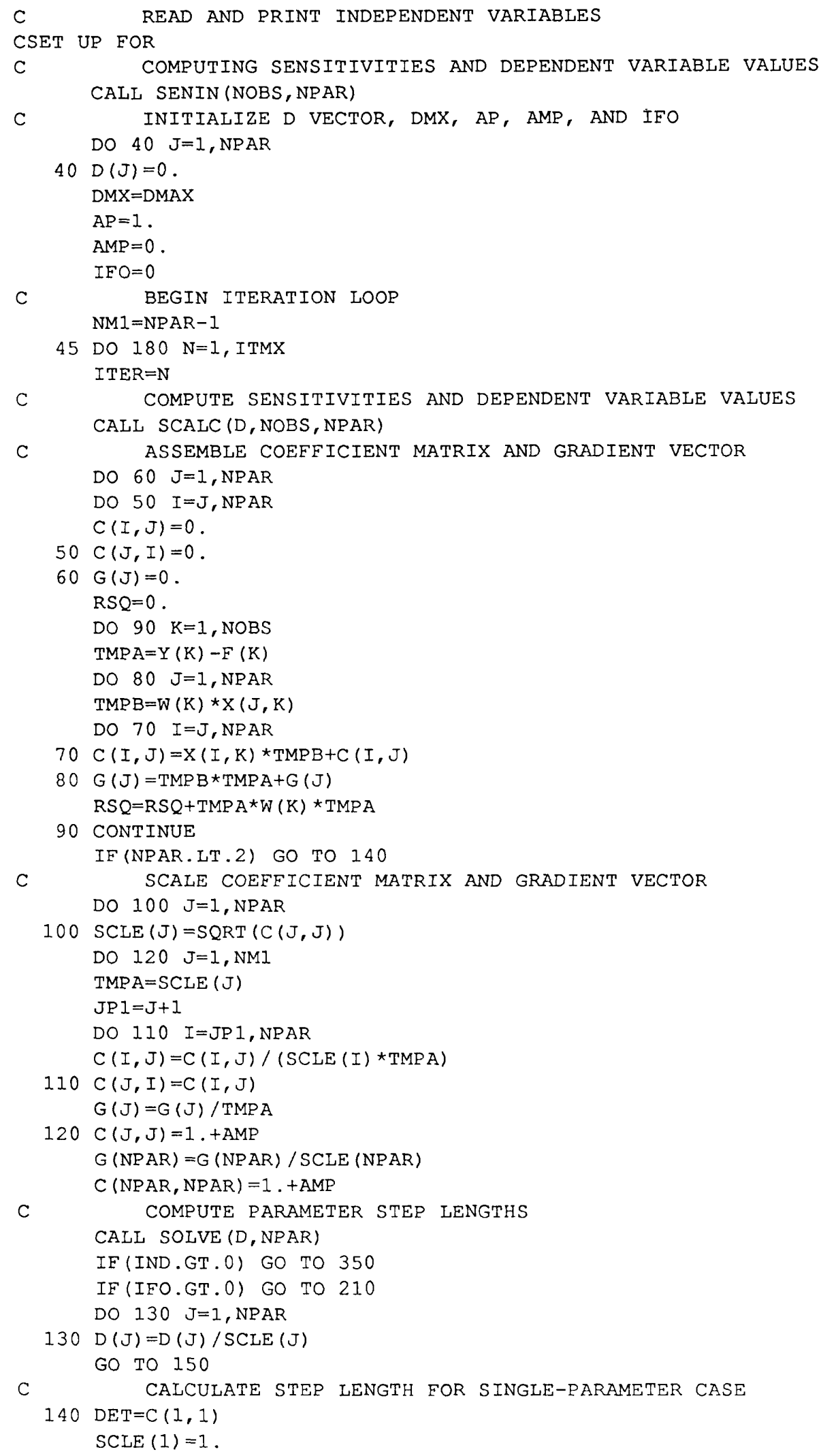




\section{APPENDIX A. PROGRAM IISTING (continued)}

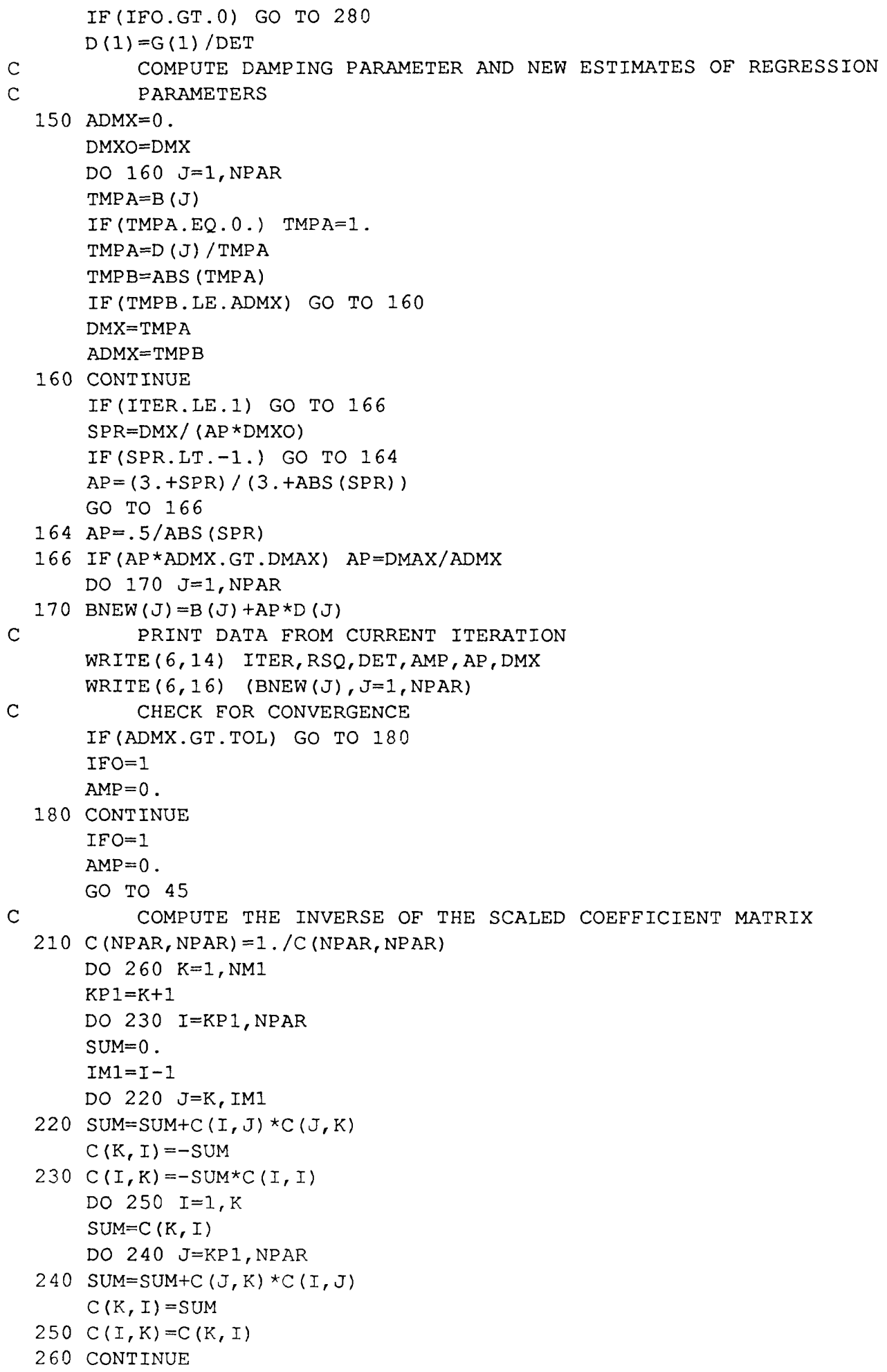




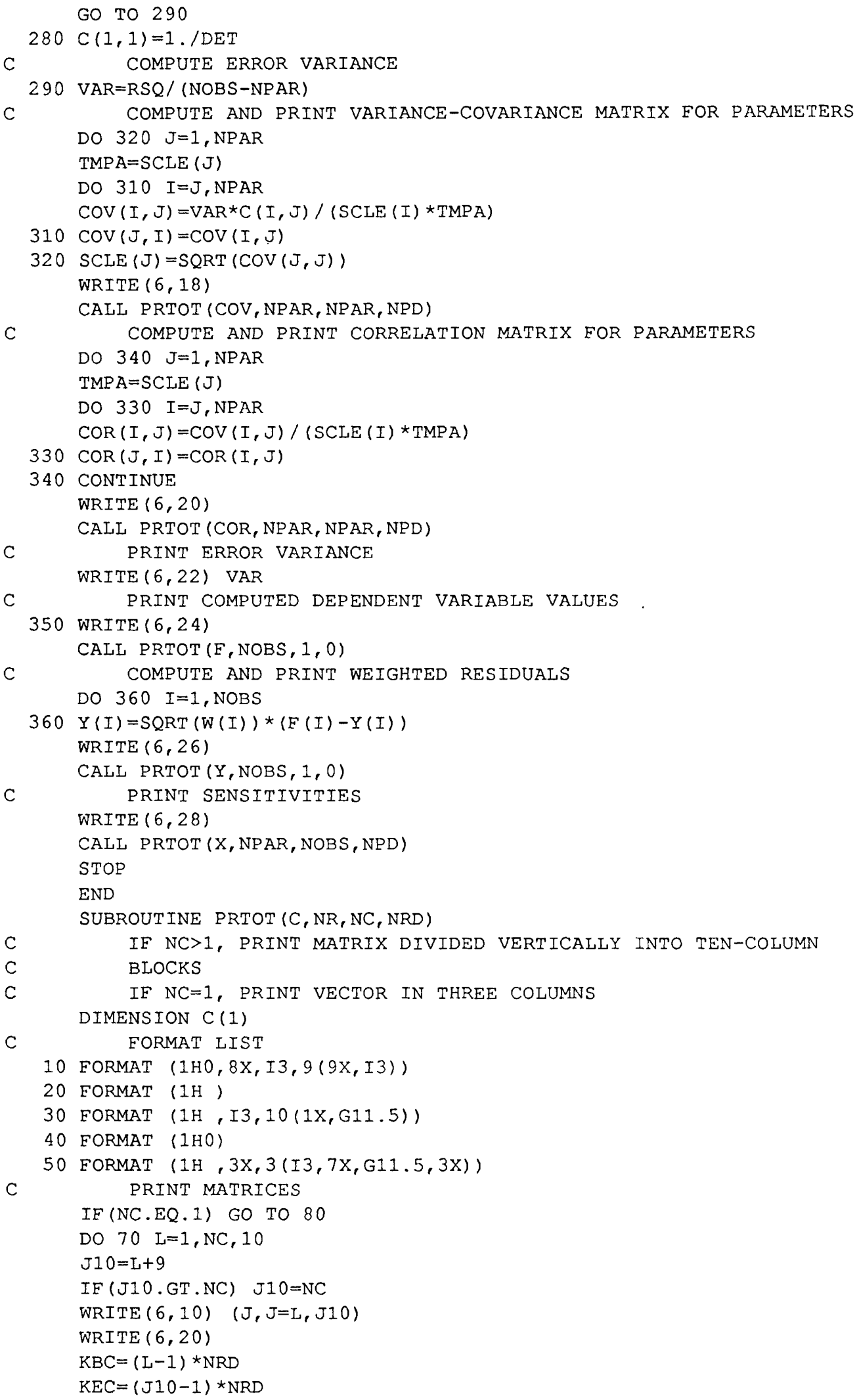




\section{APPENDIX A. PROGRAM IISTING (continued)}

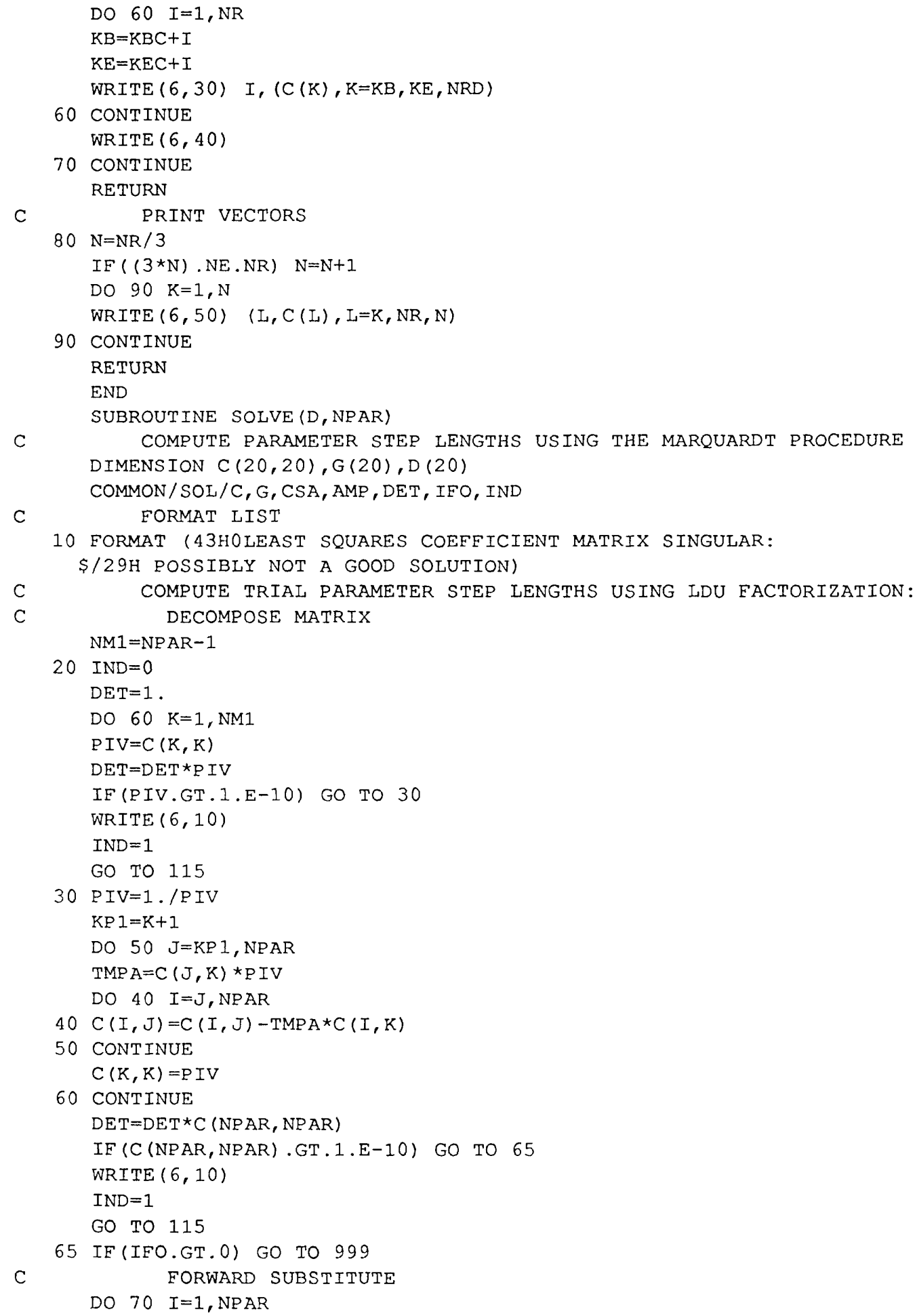




\section{APPENDIX A. PROGRAM LISTING (continued)}

$70 \quad D(I)=G(I)$

DO $80 \quad K=1$, NM1

$\operatorname{TMPA}=\mathrm{D}(\mathrm{K}){ }^{\star} \mathrm{C}(\mathrm{K}, \mathrm{K})$

$\mathrm{KP} 1=\mathrm{K}+1$

DO $75 \mathrm{~J}=\mathrm{KP} 1$, NPAR

$75 \mathrm{D}(\mathrm{J})=\mathrm{D}(\mathrm{J})-\mathrm{C}(\mathrm{J}, \mathrm{K})$ *TMPA

80 CONTINUE

C

BACK SUBSTITUTE

$D($ NPAR $)=D($ NPAR $) / C($ NPAR, NPAR $)$

$I=N P A R$

$85 \mathrm{I}=\mathrm{I}-1$

IF (I.LT.1) GO TO 100

IP $1=I+1$

SUM $=0$.

DO $90 \mathrm{~J}=I P 1$, NPAR

$90 \mathrm{SUM}=\mathrm{SUM}+\mathrm{C}(\mathrm{J}, \mathrm{I}) \star \mathrm{D}(\mathrm{J})$

$D(I)=(D(I)-S U M) * C(I, I)$

GO TO 85

C CHECK SOLUTION AND ADD MARQUARDT PARAMETER IF NEEDED

100 SUM $=0$.

SUMA $=0$.

SUMB $=0$.

DO $110 \quad I=1, N P A R$

$\mathrm{SUM}=\mathrm{SUM}+\mathrm{D}(\mathrm{I}) *_{\mathrm{G}}(\mathrm{I})$

SUMA $=S U M A+D(I) * D(I)$

$110 \mathrm{SUMB}=\mathrm{SUMB}+\mathrm{G}(\mathrm{I}) * \mathrm{G}(\mathrm{I})$

IF (SUM.GT.CSA*SQRT (SUMA*SUMB)) GO TO 999

$115 \mathrm{AMP}=1.5 \star \mathrm{AMP}+.001$

IF (AMP.GT.1.) GO TO 999

DO $130 \quad I=1$, NPAR

$C(I, I)=1 .+A M P$

DO $120 \mathrm{~J}=\mathrm{I}, \mathrm{NPAR}$

$120 \mathrm{C}(\mathrm{J}, \mathrm{I})=\mathrm{C}(\mathrm{I}, \mathrm{J})$

130 CONTINUE

GO TO 20

999 RETURN

END

SUBROUTINE SENIN (NTOT, NPAR)

C READ SENSITIVITIES

C COMPUTE INITIAL DEPENDENT

C VARIABLE VALUES FOR LINEAR REGRESSION

DIMENSION $F(50), X(20,50), B(20)$

COMMON/SEN/F, X, B

C FORMAT LIST

10 FORMAT (8F10.0)

30 FORMAT ( $1 \mathrm{H} 0,13 \mathrm{X}, 45 \mathrm{HINITIAL}$ COMPUTED VALUES OF DEPENDENT VARIABLE

$\$ / 1 \mathrm{H}, 3(4 \mathrm{X}, 3 \mathrm{HNO} ., 11 \mathrm{X}, 1 \mathrm{HY}, 5 \mathrm{X}))$

C READ SENSITIVITIES

DO $40 \mathrm{~J}=1$, NTOT

$\operatorname{READ}(5,10) \quad(X(I, J), I=1, \operatorname{NPAR})$

40 CONTINUE

C

COMPUTE VALUES OF INITIAL DEPENDENT VARIABLE 


\section{APPENDIX A. PROGRAM LISTING (continued)}

DO $60 \mathrm{~J}=1, \mathrm{NTOT}$

$\mathrm{SUM}=0$.

DO $50 \quad I=1, N P A R$

$50 \mathrm{SUM}=\mathrm{SUM}+\mathrm{X}(I, J) \star \mathrm{B}(I)$

$60 \mathrm{~F}(\mathrm{~J})=\mathrm{SUM}$

C

PRINT VALUES OF INITIAL DEPENDENT VARIABLE

WRITE $(6,30)$

CALL PRTOT (F, NTOT, 1,0)

RETURN

END

SUBROUTINE SCALC (D, NTOT, NPAR)

C COMPUTE NEW DEPENDENT VARIABLE VALUES FOR IINEAR REGRESSION DIMENSION $\mathrm{F}(50), \mathrm{X}(20,50), \mathrm{B}(20), \mathrm{D}(20)$

COMMON/SEN/F, X, B

DO $30 \mathrm{~J}=1$, NTOT

$\mathrm{SUM}=\mathrm{E}(\mathrm{J})$

DO $20 I=1$, NPAR

$20 \mathrm{SUM}=\mathrm{SUM}+\mathrm{X}(I, J) \star \mathrm{D}(I)$

$30 \mathrm{~F}(\mathrm{~J})=\mathrm{SUM}$

RETURN

END 


\section{APPENDIX B. PROGRAM OUTPUT}

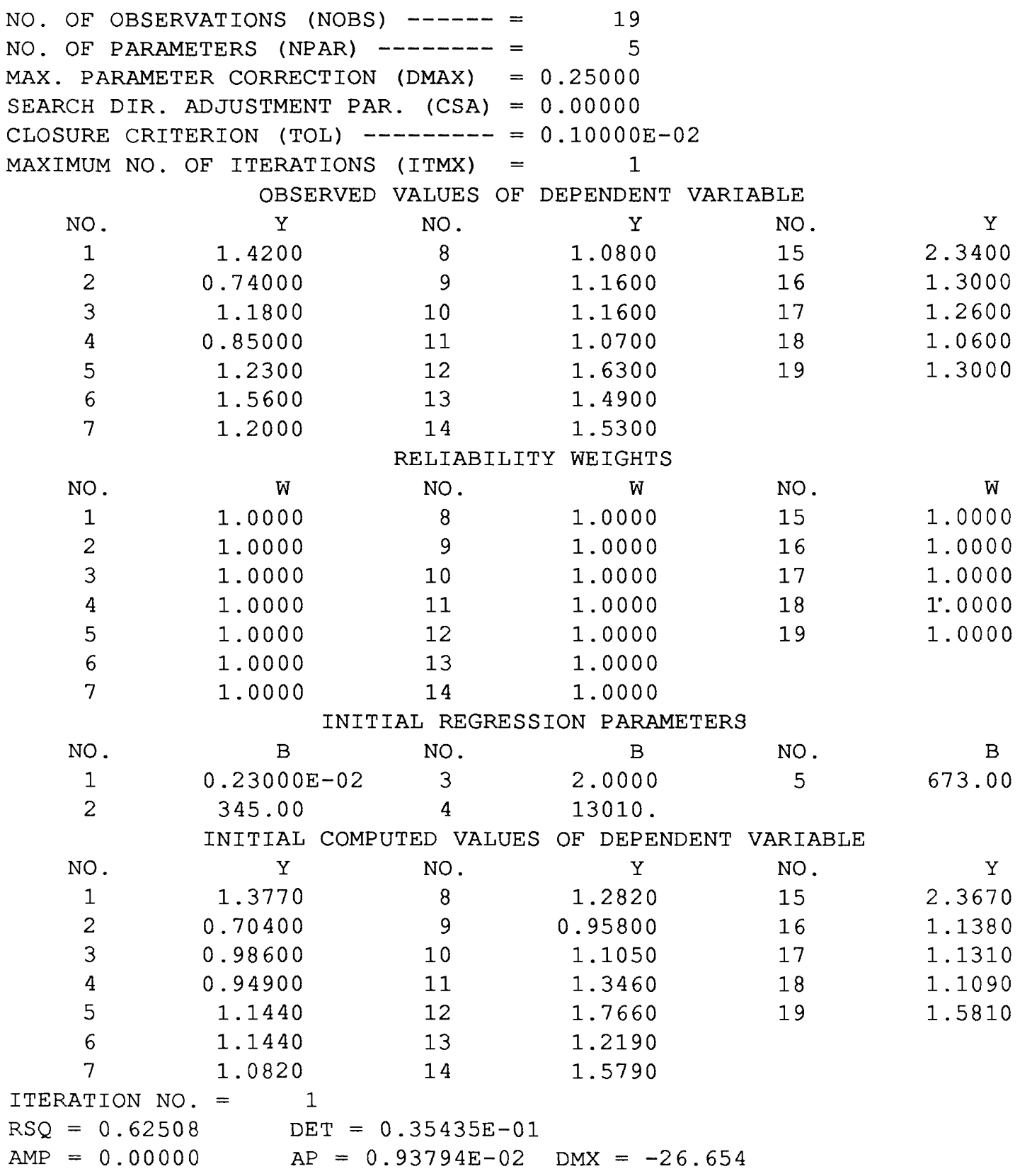




\section{APPENDIX B. PROGRAM OUTPUT (continued)}

CURRENT ESTIMATES OF REGRESSION PARAMETERS
$0.21524 \mathrm{E}-02 \quad 345.20$
1.5000
13015 .
673.10

VARIANCE-COVARIANCE MATRIX FOR PARAMETERS

1

$\begin{array}{ll}1 & 0.17772 \mathrm{E}-02 \\ 2 & 0.24356 \\ 3 & -.90164 \\ 4 & -75.353 \\ 5 & -1.6406\end{array}$
2

$$
\begin{array}{r}
0.24356 \\
4421.4 \\
-1934.5 \\
-64504 . \\
4752.7
\end{array}
$$

3

$$
\begin{array}{r}
-.90164 \\
-1934.5 \\
2015.6 \\
83803 . \\
-997.25
\end{array}
$$

$\begin{array}{ll}-75.353 & -1.6406 \\ -64504 . & 4752.7 \\ 83803 . & -997.25 \\ 0.34214 \mathrm{E}+08 & -.11481 \mathrm{E}+06 \\ -.11481 \mathrm{E}+06 & 9289.9\end{array}$

CORRELATION MATRIX FOR PARAMETERS

1

2
3

$$
\begin{array}{rr}
0.86889 E-01 & -.47639 \\
1.0000 & -.64801 \\
-.64801 & 1.0000 \\
-.16585 & 0.31912 \\
0.74158 & -.23046
\end{array}
$$

$1 \quad 1.0000$

$20.86889 \mathrm{E}-01$

$3-.47639$

$4-.30558$

$5-.40377$
4

5

ERROR VARIANCE $=0.44649 \mathrm{E}-01$ COMPUTED VALUES OF DEPENDENT VARIABLE

$\begin{array}{rlcccc}\text { NO. } & \text { F } & \text { NO. } & F & \text { NO. } & \text { F } \\ 1 & 1.3770 & 8 & 1.2820 & 15 & 2.3670 \\ 2 & 0.70400 & 9 & 0.95800 & 16 & 1.1380 \\ 3 & 0.98600 & 10 & 1.1050 & 17 & 1.1310 \\ 4 & 0.94900 & 11 & 1.3460 & 18 & 1.1090 \\ 5 & 1.1440 & 12 & 1.7660 & 19 & 1.5810 \\ 6 & 1.1440 & 13 & 1.2190 & & \\ 7 & 1.0820 & 14 & 1.5790 & & \\ & & \text { WEIGHTED } & \text { RESIDUALS } & & \\ \text { NO. } & \text { R } & \text { NO. } & \text { R } & \text { NO. } & \\ 1 & -.43000 \mathrm{E}-01 & 8 & 0.20200 & 15 & 0.27000 \mathrm{E}-01 \\ 2 & -.36000 \mathrm{E}-01 & 9 & -.20200 & 16 & -.16200 \\ 3 & -.19400 & 10 & -.55000 \mathrm{E}-01 & 17 & -.12900 \\ 4 & 0.99000 \mathrm{E}-01 & 11 & 0.27600 & 18 & 0.49000 \mathrm{E}-01 \\ 5 & -.86000 \mathrm{E}-01 & 12 & 0.13600 & 19 & 0.28100 \\ 6 & -.41600 & 13 & -.27100 & & \\ 7 & -.11800 & 14 & 0.49000 \mathrm{E}-01 & & \end{array}$




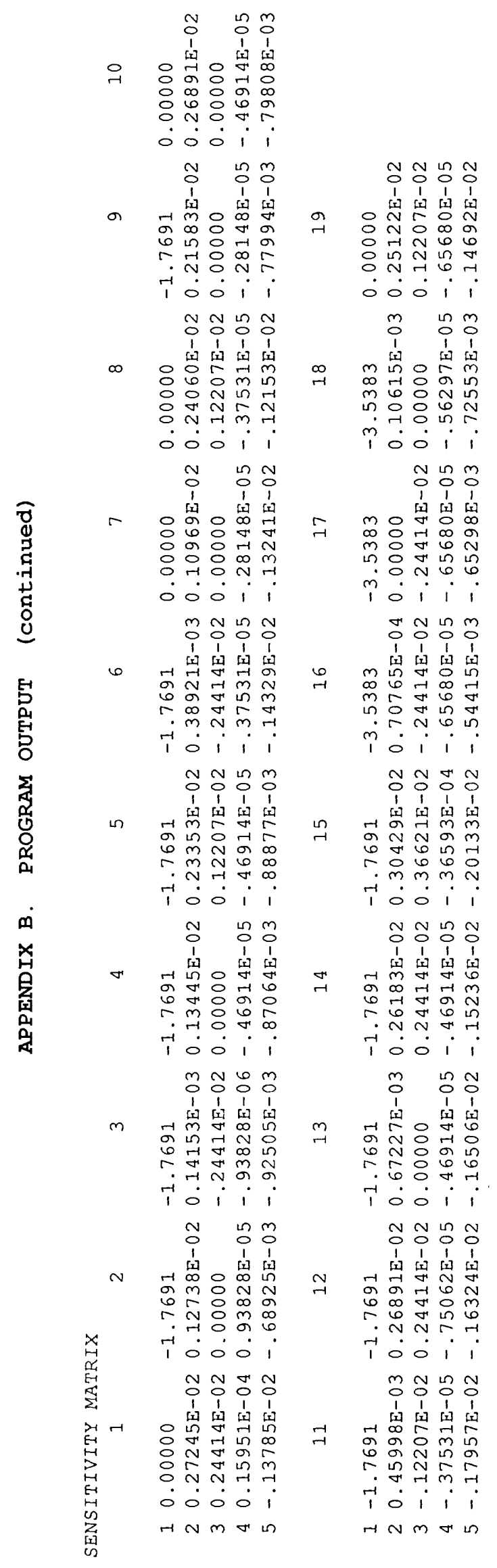

